\title{
Meteorological Data for Selected Sites along the Colorado River Corridor, Arizona, 2011-13
}

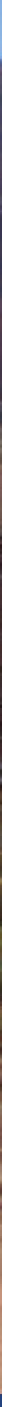

Open-File Report 2014-1247 
Cover: Southern view from a monitoring station in Furnace Flats, Grand Canyon National Park, Arizona. Photograph by Joshua Caster, U.S. Geological Survey Grand Canyon Monitoring and Research Center. 


\section{Meteorological Data for Selected Sites along the Colorado River Corridor, Arizona, 2011-13}

By Joshua Caster, Timothy Dealy, Timothy Andrews, Helen Fairley, Amy Draut, and Joel Sankey

Open-File Report 2014-1247

U.S. Department of the Interior

U.S. Geological Survey 


\section{U.S. Department of the Interior \\ SALLY JEWELL, Secretary}

\section{U.S. Geological Survey Suzette Kimball, Acting Director}

U.S. Geological Survey, Reston, Virginia: 2014

For more information on the USGS - the Federal source for science about the Earth, its natural and living resources, natural hazards, and the environment-visit http://www.usgs.gov or call 1-888-ASK-USGS

For an overview of USGS information products, including maps, imagery, and publications, visit http://www.usgs.gov/pubprod

To order this and other USGS information products, visit http://store.usgs.gov

Suggested citation:

Caster, J., Dealy, T., Andrews, T, Fairley, H., Draut, A., and Sankey, J., 2014, Meteorological data for selected sites along the Colorado River Corridor, Arizona, 2011-13: U.S. Geological Survey Open-File Report 2014-1247, 56 p., http://dx.doi.org/10.3133/ofr20141247.

ISSN 2331-1258 (online)

Any use of trade, product, or firm names is for descriptive purposes only and does not imply endorsement by the U.S. Government.

Although this report is in the public domain, permission must be secured from the individual copyright owners to reproduce any copyrighted material contained within this report. 


\section{Contents}

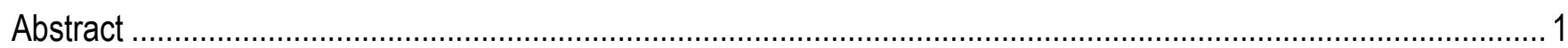

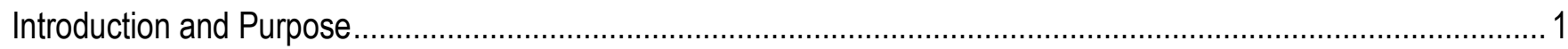

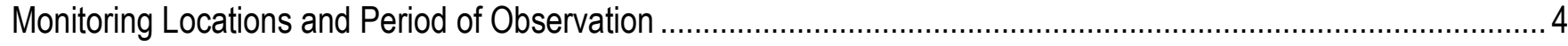

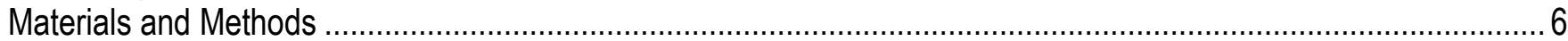

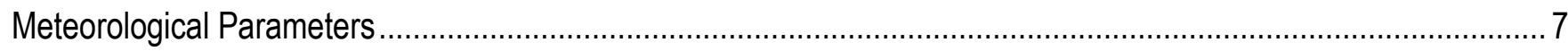

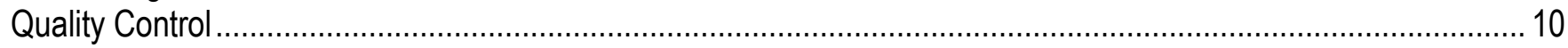

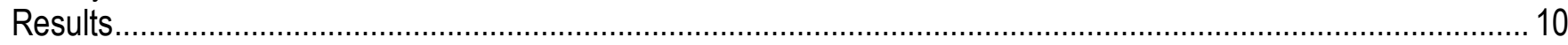

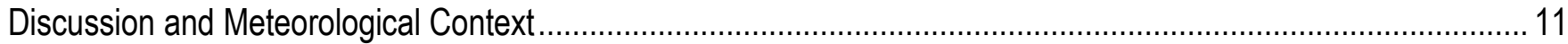

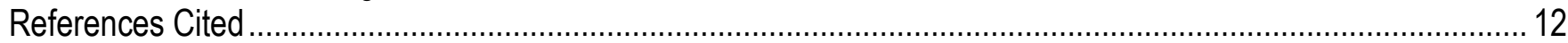

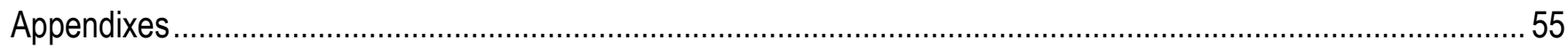

Appendix 1. Explanation of Data Gaps within the Recording Period.............................................................. 55

Appendix 2. Potential Errors Identified during Quality Assessment...............................................................5

Appendix 3. Meteorological Data for Seven Weather Parameters, Glen Canyon Recreation Area, Arizona,

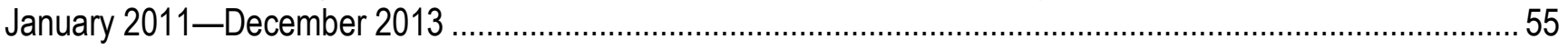

Appendix 4. Meteorological Data for Seven Weather Parameters, Grand Canyon National Park, Arizona,

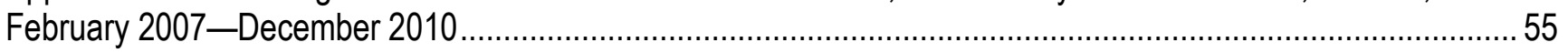

\section{Figures}

Figure 1. Map showing locations of weather monitoring sites the Colorado River Corridor through Glen and

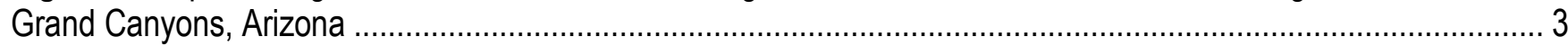

Figure 2. Photograph showing automated weather station ......................................................................... 6

Figure 3. Polar plots showing seasonal wind speed means, maximum wind gusts, wind vector sums for wind speeds greater than 2 meters per second, and the total number (frequency) of 4-minute records by azimuth (in respect to true north).

Figure 4. Graphs showing mean wind speeds recorded for 12-hour day (6 a.m.-6 p.m.) and night (6 p.m.-6 a.m.), January 1, 2011, through December 31, 2013

Figure 5. Graphs showing maximum wind gusts recorded for 12 -hour day (6 a.m.-6 p.m.) and night (6 p.m.-6 a.m.), January 1, 2011, through December 31, 2013.

Figure 6. Graphs showing mean air temperature recorded for 12-hour day (6 a.m.-6 p.m.) and night

(6 p.m.-6 a.m.), January 1, 2011, through December 31, 2013

Figure 7. Graphs showing mean relative humidity recorded for 12 -hour day ( 6 a.m.-6 p.m.) and night

(6 p.m.-6 a.m.), January 1, 2011, through December 31, 2013

Figure 8. Graphs showing mean barometric pressure recorded for 12 -hour day (6 a.m.-6 p.m.) and night (6 p.m.-6 a.m.), January 1, 2011, through December 31, 2013 46

Figure 9. Graphs showing cumulative daily rainfall and maximum daily 10-minute precipitation intensity, January 1, 2011, through December 31, 2013. 


\section{Tables}

Table 1. Description of weather monitoring sites and stations, Colorado River Corridor, Grand Canyon, Arizona, 2011-13.

Table 2. Manufacturer's stated accuracy and resolution for the VaisalaTM WXT510/520 Weather Transmitter

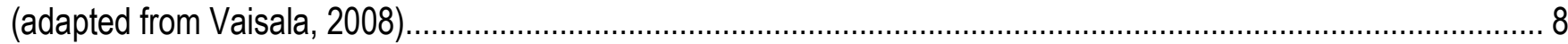

Table 3. Weather parameters, instrumentation, collection methods, and expected range of values...................... 9

Table 4. Rainfall totals for the reporting period in millimeters per day

\section{Conversion Factors}

Inch/Pound to SI

\begin{tabular}{lll}
\hline \multicolumn{1}{c}{ Multiply } & \multicolumn{1}{c}{ By } & \multicolumn{1}{c}{ To obtain } \\
\hline inch (in.) & 25.4 & millimeter (mm) \\
inch of mercury at $32^{\circ} \mathrm{F}$ (in $\left.\mathrm{Hg}\right)$ & 33.8638867 & millibars (mbar) \\
mile (mi) & 1.609 & kilometer $(\mathrm{km})$ \\
mile per hour (mi $/ \mathrm{h})$ & 0.44704 & meter per second $(\mathrm{m} / \mathrm{s})$ \\
\hline
\end{tabular}

SI to Inch/Pound

\begin{tabular}{lll}
\hline \multicolumn{1}{c}{ Multiply } & \multicolumn{1}{c}{ By } & \multicolumn{1}{c}{ To obtain } \\
\hline millimeter $(\mathrm{mm})$ & 0.03937 & inch (in.) \\
meter per second $(\mathrm{m} / \mathrm{s})$ & 3.281 & foot per second (ft/s) \\
millibars (mbar) & 0.02953 & inch of mercury at $32^{\circ} \mathrm{F}(\mathrm{in} \mathrm{Hg})$ \\
\hline
\end{tabular}

Temperature in degrees Celsius $\left({ }^{\circ} \mathrm{C}\right)$ may be converted to degrees Fahrenheit $\left({ }^{\circ} \mathrm{F}\right)$ as follows:

${ }^{\circ} \mathrm{F}=\left(1.8 \times{ }^{\circ} \mathrm{C}\right)+32$. 


\title{
Meteorological Data for Selected Sites along the Colorado River Corridor, Arizona, 2011-13
}

By Joshua Caster, Timothy Dealy, Timothy Andrews, Helen Fairley, Amy Draut, Joel Sankey, and David Bedford

\begin{abstract}
This report presents data from 14 automated weather stations collected as part of an ongoing monitoring program within the Grand Canyon National Park and Glen Canyon Recreation Area along the Colorado River Corridor in Arizona. Weather data presented in this document include precipitation, wind speed, maximum wind gusts, wind direction, barometric pressure, relative humidity, and air temperature collected by the Grand Canyon Monitoring and Research Center at 4-minute intervals between January 1, 2011, and December 31, 2013, using automated weather stations consisting of a data logger and a weather transmitter equipped with a piezoelectric sensor, ultrasonic transducers, and capacitive thermal and pressure sensors. Data collection was discontinuous because of station additions, station removals, changes in permits, and equipment failure. A large volume of data was collected for each station. These data are part of a larger research effort focused on physical processes affecting landscapes and archaeological-site stability in the Colorado River Corridor-both natural processes (including meteorological events) and those related to the Glen Canyon Dam operations. Meteorological conditions during the study interval were warmer and drier than is typical, due to ongoing drought conditions during the time period studied. The El Niño/Southern Oscillation was primarily in a neutral state during the reporting period.
\end{abstract}

\section{Introduction and Purpose}

The Colorado River within the Grand Canyon National Park, Arizona, has been regulated since construction of the Glen Canyon Dam in 1963. To assess potential impacts on downstream cultural, environmental, and recreational resources caused by changes in the river flow regime and sediment supply, the Bureau of Reclamation (Reclamation) initiated the Glen Canyon Dam Adaptive Management Program (U.S. Department of the Interior, 1995). As part of this initiative, the U.S. Geological Survey (USGS) Grand Canyon Monitoring and Research Center (GCMRC) and its cooperators monitor the effects of dam operations. 
Monitoring efforts by the GCMRC have focused on a variety of parameters to assess downstream effects of Glen Canyon Dam. In 2003, meteorological data collection began as part of a study to relate geomorphic changes to meteorological events at and upslope of the active channel within the Colorado River Corridor. The weather data described here, and those collected previously, are part of a larger research effort focused on physical processes affecting archaeological-site stability in the Colorado River corridor - both natural processes (including meteorological events) and those related to dam operations. This research effort involves assessing relations between physical landscape processes, including meteorological events, and the physical integrity of archaeological sites. Measuring meteorological conditions and, in a separate but related effort, measuring sediment erosion and deposition in selected areas of the river-corridor landscape, allows researchers to identify natural and dam-induced changes to the river corridor. Meteorological data will be used in this larger research effort to evaluate the potential restorative effects of high-flow releases from the Glen Canyon Dam, including the monitoring of windblown sand supply from new river sandbars toward upland archaeological sites (Draut and Rubin, 2008; Draut and others, 2010a; Draut, 2012), precipitation-induced erosion (Collins and others, in press), gullying, and gully annealing by windblown sediment (Sankey and Draut, 2014).

Weather data collection between 2003 and 2006 used spinning-cup anemometers and tippingbucket rain gages with an automated data logger to measure 4-minute wind direction, wind speed, maximum wind gusts, and precipitation at nine locations within the Grand Canyon, Arizona (Draut and Rubin, 2005; Draut and Rubin, 2006). The 4-minute time interval for data collection was selected as it provided the highest resolution information that would not exceed the data logger storage capacity between scheduled data collection operations.

Beginning in February 2007, GCMRC installed 11 new weather stations at 9 sites within the Colorado River Corridor; 4 of the station locations were used during the previous study by Draut and others (2009a). These weather stations consisted of a data logger and an automated weather transmitter with a piezoelectric sensor, ultrasonic transducers, and capacitive thermal and pressure sensors to collect multiple weather parameters (wind direction, wind speed, maximum wind gusts, precipitation, temperature, barometric pressure, and relative humidity) at 4-minute intervals without moving parts. Data collected from these 9 weather monitoring sites for 2007, 2008, 2009, and 2010 have been presented in previous reports by Draut and others (2009, 2009b, 2010b) and Dealy and others(2014). Following a hiatus in data collection, 8 of the 11 stations were removed in 2012 . The three remaining stations (AZ C:05:0031 Upper, AZ C:13:0346 Upper, AZ G:03:0072) as well as three new stations (AZ C:02:0071, AZ C:02:070, AZ B:10:0225) were activated in spring 2013 and are still operating as of spring 2014. 
The purpose of this report is to present data collected by GCMRC weather stations between January 1, 2011, and December 31, 2013, and to establish a process for reporting future weather data. Weather parameters during this period were collected from the 11 automated stations that were used for previous reports by Draut and others (2009a, 2009b, 2010b, and Dealy and others, 2014) that were in operation through fall 2011, three of which were reactivated in 2013, and three additional automated weather stations deployed in 2013 at sites AZ C:02:0071, AZ C:02:070, and AZ B:10:0225 (fig. 1). Reported meteorological data from these 14 automated weather stations were wind direction, wind speed, maximum wind gusts, air temperature, barometric pressure, relative humidity, and rainfall. Records from all 14 stations are fragmentary because of station removal, staggered station installation, equipment malfunction, and monitoring permit modification. Explanations of gaps within the data collected from the automated weather stations are included in this report and a detailed list is provided in appendix 1.

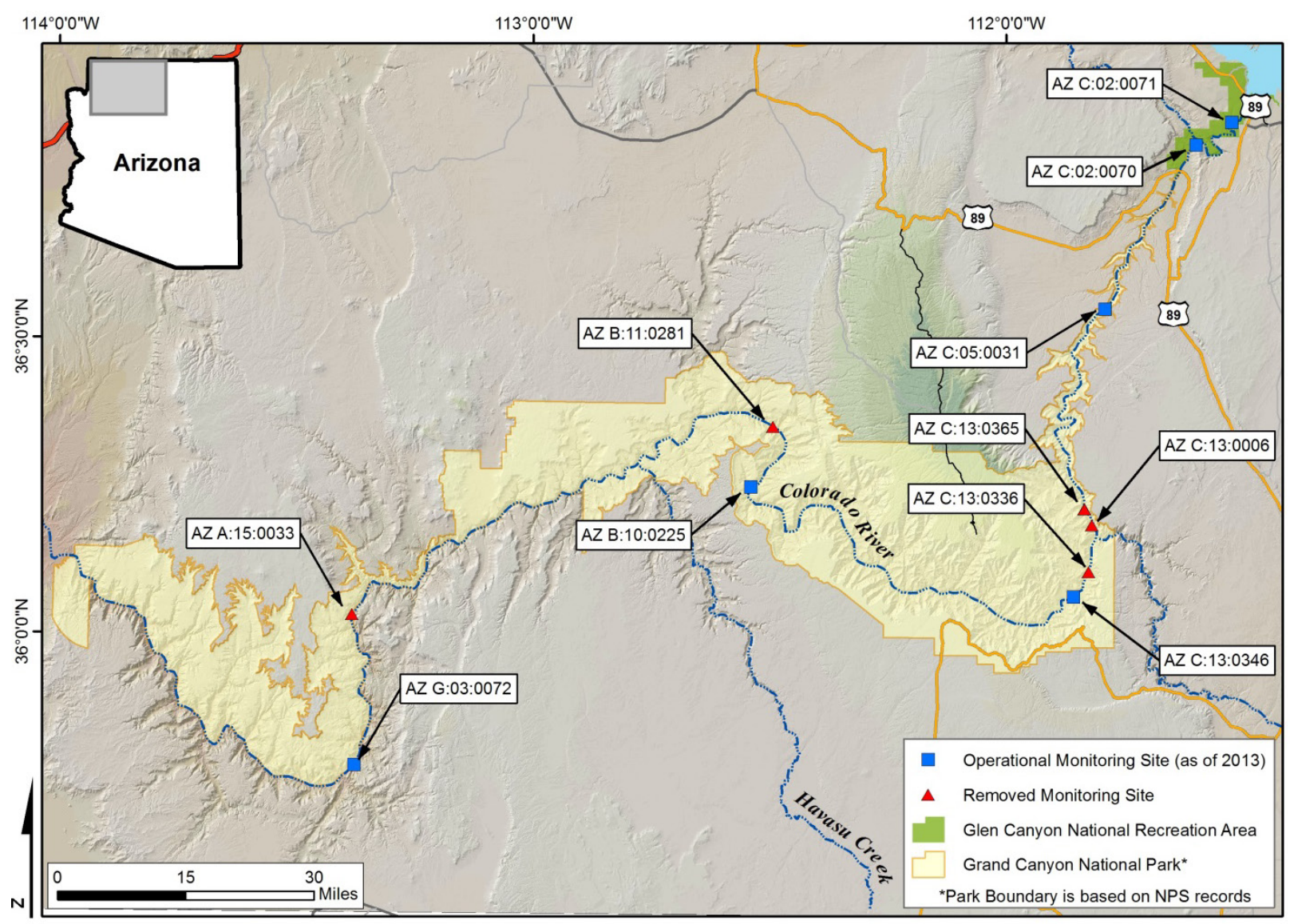

Figure 1. Map showing locations of weather monitoring sites the Colorado River Corridor through Glen and Grand Canyons, Arizona. There are 14 automated weather stations within 11 monitoring sites. Sites AZ C:05:0031, AZ C:13:0365, and AZ C:13:0346 contained two stations prior to 2012. After summer 2011, all operational monitoring sites contained only one station. 


\section{Monitoring Locations and Period of Observation}

GCMRC monitored 14 automated weather stations at 11 monitoring sites for at least a portion of the reporting period from January 2011 to December 2013. Site locations were selected based on the potential for gully erosion and aeolian influx of fluvial sand deposited upwind of the site along flood shorelines (Draut and Rubin, 2005). These weather monitoring sites were distributed along approximately 230 river miles of the Colorado River corridor within the Grand Canyon National Park and the Glen Canyon Recreation Area. Distances between monitoring sites ranged from 2 to 68 river miles. Three of these monitoring sites contained two weather stations for the purpose of assessing intrasite variability and quality control of readings. Monitoring sites have been designated with a 7-digit alpha-numeric code corresponding to previous reports (Draut and others, 2009a, 2009b, 2010b). Where two stations were present at a monitoring site, a qualifier of Upper, for the upstream station in respect to the Colorado River, or Lower, for the downstream station, was added to the designation.

None of the 14 automated weather stations collected data for the entire reporting period from January 1, 2011, through December 31, 2013. Data collection for all sites ceased between November 22, 2011, and April 27, 2013, following a transitional period between the National Park Service research and monitoring permits. After the issuance of the 2013 permit, only three of the automated weather stations deployed in 2007 were re-activated (AZ C:05:0031Upper, AZ C:13:0346 Upper, AZ G:03:0072), and three new stations (AZ C:02:0071, AZ C:02:070, AZ B:10:0225) were installed. Four of the six stations in operation during 2013 retained a continuous record between installation and the end of the reporting period. Data collection was disrupted for sites AZ B:10:0225 and AZ G:03:0072 because of power loss and station removal, respectively. A summary of station names, locations, and operational periods is presented in table 1 and a comprehensive list of gaps within the data is provided in appendix 1. 
Table 1. Description of weather monitoring sites and stations, Colorado River Corridor, Grand Canyon, Arizona, 2011-13.

[Stations are listed in order from upstream (in respect to the Colorado River) to downstream]

\begin{tabular}{|c|c|c|c|c|c|}
\hline $\begin{array}{l}\text { Monitoring } \\
\text { site }\end{array}$ & $\begin{array}{l}\text { Monitoring } \\
\text { station }\end{array}$ & $\begin{array}{l}7.5 \text { minute } \\
\text { quadrangle }\end{array}$ & Geographic description & $\begin{array}{l}\text { Topographic } \\
\text { description }\end{array}$ & Operational period \\
\hline AZ C:02:0071 & AZ C:02:0071 & Ferry Swale & $\begin{array}{l}\text { Near the confluence of } \\
\text { Ferry Swale Canyon and } \\
\text { the Colorado River. }\end{array}$ & $\begin{array}{l}\text { Within a shallow } \\
\text { depression on a point } \\
\text { bar. }\end{array}$ & $\begin{array}{c}\text { Nov 5, } 2013 \text { to } \\
\text { Dec } 31,2013\end{array}$ \\
\hline AZ C:02:0070 & AZ C:02:0070 & Lees Ferry & $\begin{array}{l}\text { Near the confluence of the } \\
\text { Paria and the Colorado } \\
\text { Rivers. }\end{array}$ & On a cobble bar. & $\begin{array}{l}\text { Jun } 12,2013 \text { to } \\
\text { Dec } 31,2013\end{array}$ \\
\hline AZ C:05:0031 & $\begin{array}{l}\text { AZ C:05:0031 } \\
\text { Upper } \\
\\
\text { AZ C:05:0031 } \\
\quad \text { Lower }\end{array}$ & $\begin{array}{l}\text { North Canyon } \\
\text { Point }\end{array}$ & $\begin{array}{l}\text { Near the confluence of } \\
\text { Sheep Spring Wash and the } \\
\text { Colorado River. }\end{array}$ & $\begin{array}{l}\text { On the proximal } \\
\text { portion of a debris fan. }\end{array}$ & $\begin{array}{l}\text { Jan 1, 2011 to } \\
\text { Jul 28, } 2011 \\
\text { Apr 27, } 2013 \text { to } \\
\text { Dec 29, } 2013 \\
\text { Jan 1, 2011 to } \\
\text { Jul 28, } 2011\end{array}$ \\
\hline AZ C:13:0365 & $\begin{array}{c}\text { AZ C: } 13: 0365 \\
\text { Upper } \\
\text { AZ C:13:0365 } \\
\text { Lower }\end{array}$ & Cape Solitude & $\begin{array}{l}\text { Near the confluence of } \\
\text { Malgosa Creek and the } \\
\text { Colorado River. }\end{array}$ & $\begin{array}{l}\text { Along a minor } \\
\text { distributary of Malgosa } \\
\text { Creek. }\end{array}$ & $\begin{array}{l}\text { Jan 1, 2011 to } \\
\text { Jul 31, } 2011 \\
\text { Jan 1, } 2011 \text { to } \\
\text { Jul 31, } 2011\end{array}$ \\
\hline AZ C:13:0006 & AZ C:13:0006 & Cape Solitude & $\begin{array}{l}\text { Near the confluence of } \\
\text { Sixtymile Creek and the } \\
\text { Colorado River. }\end{array}$ & $\begin{array}{l}\text { On the proximal } \\
\text { portion of a debris fan. }\end{array}$ & $\begin{array}{l}\text { Jan } 1,2011 \text { to } \\
\text { Jun } 22,2011\end{array}$ \\
\hline AZ C:13:0336 & AZ C:13:0336 & Cape Solitude & $\begin{array}{l}\text { Near the confluence of } \\
\text { Palisades Creek and the } \\
\text { Colorado River. }\end{array}$ & $\begin{array}{l}\text { On the proximal } \\
\text { portion of a } \\
\text { reattachment bar. }\end{array}$ & $\begin{array}{l}\text { Jan 1, 2011 to } \\
\text { Aug 2, } 2011\end{array}$ \\
\hline AZ C:13:0346 & $\begin{array}{l}\text { AZ C: } 13: 0346 \\
\text { Upper } \\
\\
\text { AZ C: } 13: 0346 \\
\quad \text { Lower }\end{array}$ & Desert View & $\begin{array}{l}\text { Near the confluence of } \\
\text { Basalt Creek and the } \\
\text { Colorado River }\end{array}$ & $\begin{array}{l}\text { On a terrace in a } \\
\text { largely inactive aeolian } \\
\text { dune field. }\end{array}$ & $\begin{array}{l}\text { Jan 1, 2011 to } \\
\text { Aug 2, } 2011 \\
\text { May 2, } 2013 \text { to } \\
\text { Dec 31, } 2013 \\
\text { Jan 1, 2011 to } \\
\text { Nov 22, } 2011\end{array}$ \\
\hline AZ B:10:0225 & AZ B:10:0225 & Fossil Bay & $\begin{array}{l}\text { Near the confluence of } \\
\text { Fossil Canyon and the } \\
\text { Colorado River. }\end{array}$ & $\begin{array}{l}\text { On the proximal } \\
\text { portion of a debris fan. }\end{array}$ & $\begin{array}{l}\text { May 6, } 2013 \text { to } \\
\text { Nov } 1,2013\end{array}$ \\
\hline AZ B:11:0281 & AZ B:11:0281 & $\begin{array}{l}\text { Tapeats } \\
\text { Amphitheater }\end{array}$ & $\begin{array}{l}\text { Near the confluence of } \\
\text { Bonita Creek and the } \\
\text { Colorado River. }\end{array}$ & $\begin{array}{l}\text { On the medial portion } \\
\text { of a debris fan. }\end{array}$ & $\begin{array}{l}\text { Jan 1, 2011 to } \\
\text { Feb 27, } 2011\end{array}$ \\
\hline AZ A:15:0033 & AZ A:15:0033 & $\begin{array}{l}\text { Whitmore } \\
\text { Point SE }\end{array}$ & $\begin{array}{l}\text { Near the confluence of } \\
\text { Spring Canyon and the } \\
\text { Colorado River. }\end{array}$ & $\begin{array}{l}\text { On the medial portion } \\
\text { of a reattachment bar. }\end{array}$ & $\begin{array}{l}\text { Jan 1, 2011 to } \\
\text { Aug 6, } 2011\end{array}$ \\
\hline AZ G:03:0072 & AZ G:03:0072 & $\begin{array}{l}\text { Diamond } \\
\text { Peak }\end{array}$ & $\begin{array}{l}\text { Near the confluence of Two } \\
\text { Hundred and Twentyfour } \\
\text { Mile Canyon and the } \\
\text { Colorado River. }\end{array}$ & $\begin{array}{l}\text { On the medial portion } \\
\text { of a debris fan. }\end{array}$ & $\begin{array}{c}\text { Jan } 1,2011 \text { to } \\
\text { Aug } 11,2011 \\
\text { May } 11,2013 \text { to } \\
\text { Jul } 5,2013\end{array}$ \\
\hline
\end{tabular}




\section{Materials and Methods}

Data collection was conducted using automated weather stations. Each station (fig. 2) consists of a transmitter and data logger mounted on a tripod and powered by a 12-volt deep cycle 55-amp-hour AGM Optima battery (model D34/78) enclosed in a plastic box at the base of the tripod. The battery is charged by a 30 watt BP Solar multicrystalline photovoltaic module (BP SX30U). The solar module is mounted to the tripod with an Ameresco Solar's HPM18-30U horizontal pole mount system and is regulated by Morningstar Corporation's SunKeeper ${ }^{\mathrm{TM}}$ 6-amp 12 VDC solar charge controller.

The transmitters used for each station are Vaisala ${ }^{\mathrm{TM}}$ type WXT510 or WXT520 that measure air temperature, barometric pressure, precipitation, relative humidity, wind speed, and wind direction. The Vaisala $^{\mathrm{TM}}$ WXT510/520 transmitter was selected because it could collect multiple parameters without moving parts that reduce visibility to canyon visitors and because of the potential for equipment malfunction associated with moving parts in a desert environment, such as interference from windblown sand.

Data are collected from the Vaisala ${ }^{\mathrm{TM}}$ transmitter using a NexSens ${ }^{\mathrm{TM}}$ Technology data logger. The NexSens Technology, Incorporated Intelligent Sensor Interface and Control (iSIC) data logger is a 2-megabyte remote data acquisition system that is housed in a weather-proof fiberglass enclosure and has an operating temperature range of -20 to $60{ }^{\circ} \mathrm{C}$.

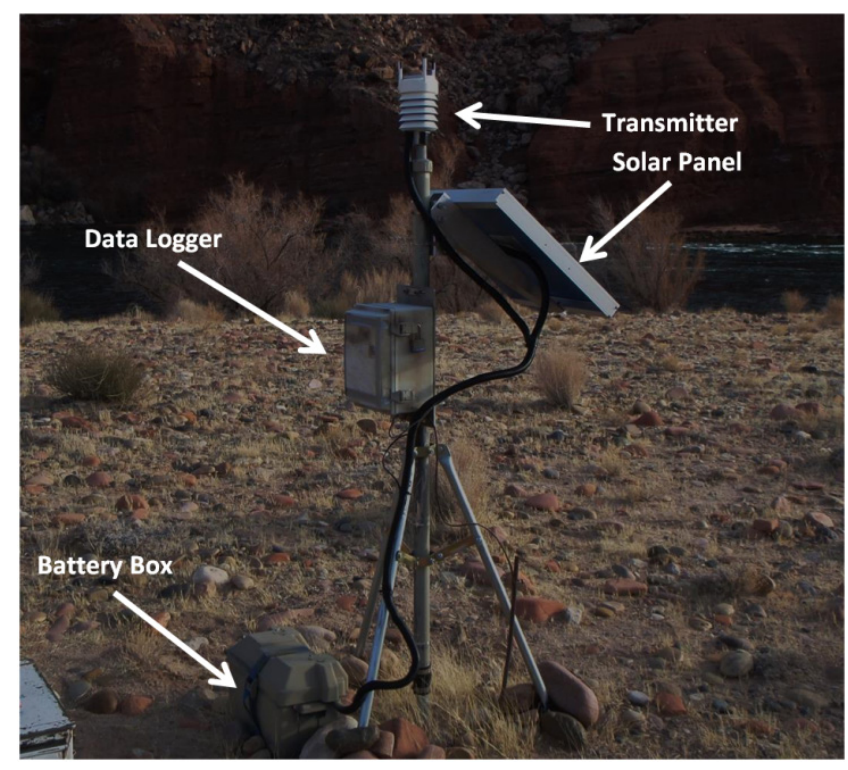

Figure 2. Photograph showing automated weather station. Photograph by Joshua Caster, U.S. Geological Survey. 
Each transmitter station is mounted on a tripod assembly made from a Ronard Industries, Inc. extra heavy duty tripod that was used to hold an electric metallic tube (EMT) conduit mast in place. The mast is attached with a Fernco coupler to a length of EMT that is driven between 0.5 and $1 \mathrm{~m}$ into the ground. The tripod and mast assembly is adjusted so that the transmitter is $2 \mathrm{~m}$ above ground. The transmitter is then oriented to true north based on magnetic declination collected from the National Oceanic and Atmospheric Administration's (NOAA) National Geophysical Data Center's Magnetic Field Calculator using the World Magnetic Model (Maus and others, 2010).

The NexSens ${ }^{\mathrm{TM}}$ Technology, Inc. data loggers are programmed to collect data at 4-minute intervals until the maximum data storage capacity has been reached. The data loggers have potential to exceed maximum storage capacity after 5 months of continuous data collection for weather parameters at 4-minute intervals. To avoid loss, data are downloaded from the stations at least once every 4 months. Data are retrieved by directly connecting a field computer to the data logger using an analog cable.

\section{Meteorological Parameters}

Seven meteorological parameters are collected at each automated weather station at 4-minute intervals. Wind parameters are collected by the Vaisala ${ }^{\mathrm{TM}}$ transmitter using three top-mounted ultrasonic transducers. Based on an assessment of ultrasonic wind readings by Wauben (2005), ultrasonic transducers have the potential to overestimate wind gusts when compared to cup anemometers. Wauben (2005) concluded that the Vaisala ${ }^{\mathrm{TM}}$ system was comparable with the conventional cup anemometer and vane system in wind speed and vector during field and wind tunnel tests, although wind speeds less than $5 \mathrm{~m} / \mathrm{s}$ showed greater variation.

Precipitation is measured by the Vaisala ${ }^{\mathrm{TM}}$ transmitter with a proprietary piezoelectric sensor (Salmi and others, 2008). Basara and others (2009) concluded that piezoelectric sensors have the potential to underestimate rainfall when compared to tipping-bucket units, depending on rainfall intensity. Despite these differences, $\mathrm{R}^{2}$ values greater than 0.95 between the Vaisala ${ }^{\mathrm{TM}}$ transmitter and the tipping-bucket unit were calculated by Basara and others (2009), suggesting comparable results.

Air temperature, barometric pressure, and relative humidity are measured using a capacitive ceramic thermal sensor, a capacitive silicon pressure sensor, and a capacitive polymer moisture sensor, respectively, located inside a polycarbonate vented radiation shield. Based on manufacturer's stated range of measurements, accuracy, and resolution for these parameters (table 2), these methods meet the measurement criteria for the National Weather Service's Surface Observing Program (National Oceanic and Atmospheric Administration, 2010). 
Table 2. Manufacturer's stated accuracy and resolution for the VaisalaTM WXT510/520 Weather Transmitter (adapted from Vaisala, 2008).

\begin{tabular}{|c|c|c|}
\hline Range & Accuracy & Resolution \\
\hline \multicolumn{3}{|c|}{ Air Temperature } \\
\hline-52 to 60 degrees Celsius $\left({ }^{\circ} \mathrm{C}\right)$ & $\pm 0.3^{\circ} \mathrm{C}$ at $20^{\circ} \mathrm{C}$ & $0.1^{\circ} \mathrm{C}$ \\
\hline \multicolumn{3}{|c|}{ Atmospheric Pressure } \\
\hline 600 to 1,100 Millibars (mbar) & $\begin{array}{l} \pm 0.5 \text { mbar at } 0 \text { to } 30^{\circ} \mathrm{C} \\
\pm 1 \text { mbar at }-52 \text { to } 60^{\circ} \mathrm{C}\end{array}$ & $0.1 \mathrm{mbar}$ \\
\hline \multicolumn{3}{|c|}{ Precipitation } \\
\hline- & $5 \%$ & $\begin{array}{l}0.01 \text { millimeters with a } \\
10 \text {-second duration }\end{array}$ \\
\hline \multicolumn{3}{|c|}{ Relative Humidity } \\
\hline $\begin{array}{l}0 \text { to } 100 \% \text { Relative Humidity } \\
\text { (RH) }\end{array}$ & $\begin{array}{l} \pm 3 \% \mathrm{RH} \text { at } 0 \text { to } 90 \% \mathrm{RH} \\
\pm 5 \% \mathrm{RH} \text { at } 90 \text { to } 100 \% \mathrm{RH}\end{array}$ & $0.1 \% \mathrm{RH}$ \\
\hline \multicolumn{3}{|c|}{ Wind Speed } \\
\hline 0 to 60 meters per second $(\mathrm{m} / \mathrm{s})$ & $\begin{array}{l}\text { the greater of } \pm 0.3 \mathrm{~m} / \mathrm{s} \text { or } \pm 3 \% \text { for } 0 \text { to } 35 \mathrm{~m} / \mathrm{s} \\
5 \% \text { for } 36 \text { to } 60 \mathrm{~m} / \mathrm{s}\end{array}$ & $0.1 \mathrm{~m} / \mathrm{s}$ \\
\hline \multicolumn{3}{|c|}{ Wind Direction } \\
\hline 0 to 360 degrees Azimuth $\left(^{\circ}\right)$ & $\pm 3.0^{\circ}$ with a 0.25 second response time & $1^{\circ}$ \\
\hline
\end{tabular}


Wind direction, wind speed, air temperature, relative humidity, and barometric pressure are collected for each interval as instantaneous records every 4 minutes. Wind gusts represent the maximum wind speed for each 4-minute interval based on 4-second composite data. Rainfall values are collected as a total sum of all rain recorded during a 4-minute interval. All meteorological parameters are recorded in English units. To comply with scientific reporting standards, these data are converted to metric units using standard conversion factors. The method of data collection, the original English units for each parameter, the converted metric units, and a range of typical (expected) metric values are shown in table 3.

Table 3. Weather parameters, instrumentation, collection methods, and expected range of values.

[The expected ranges of values represent maximum and minimum 4-minute interval values, in the converted units, observed during the previous 4 years (2007-10) at the Grand Canyon Monitoring and Research Center and National Oceanic and Atmospheric Administration stations within the monitoring area. Values outside of this range do not necessarily indicate equipment error]

\begin{tabular}{|c|c|c|c|c|c|}
\hline Parameter & Instrumentation & $\begin{array}{l}\text { Method of } \\
\text { collection }\end{array}$ & $\begin{array}{c}\text { Data collection } \\
\text { units }\end{array}$ & Converted units & $\begin{array}{c}\text { Expected range } \\
\text { of values* }\end{array}$ \\
\hline Wind direction & $\begin{array}{l}\text { Ultrasonic } \\
\text { transducer }\end{array}$ & Instantaneous & $\begin{array}{l}\text { degrees azimuth } \\
\text { (true north) }\end{array}$ & not converted & $0-360$ \\
\hline Wind speed & $\begin{array}{l}\text { Ultrasonic } \\
\text { transducer }\end{array}$ & Instantaneous & miles per hour & $\begin{array}{l}\text { meters per } \\
\text { second }\end{array}$ & $0-18$ \\
\hline Wind gusts & $\begin{array}{l}\text { Ultrasonic } \\
\text { transducer }\end{array}$ & $\begin{array}{l}\text { Maximum of 4- } \\
\text { minute composite }\end{array}$ & miles per hour & $\begin{array}{l}\text { meters per } \\
\text { second }\end{array}$ & $0-27$ \\
\hline Air temperature & $\begin{array}{l}\text { Ceramic thermal } \\
\text { sensor }\end{array}$ & Instantaneous & degrees Fahrenheit & degrees Celsius & $0-54$ \\
\hline Relative humidity & $\begin{array}{l}\text { Polymer moisture } \\
\text { sensor }\end{array}$ & Instantaneous & relative percentage & not converted & $0-100$ \\
\hline $\begin{array}{l}\text { Barometric } \\
\text { pressure }\end{array}$ & $\begin{array}{l}\text { Silicon pressure } \\
\text { sensor }\end{array}$ & Instantaneous & inches mercury & millibars & $845-1,015$ \\
\hline Rainfall & Piezoelectric sensor & $\begin{array}{l}\text { Total of 4-minute } \\
\text { composite }\end{array}$ & inches & millimeters & $0-25$ \\
\hline
\end{tabular}

*Values are in the converted units. 


\section{Quality Control}

Data collected from the 14 automated weather stations were analyzed for potential inconsistencies and spurious data through outlier identification, graphical analysis, and comparative analysis. Outlier identification was conducted by flagging weather parameter values that were outside of the expected range during the initial review of the 4-minute interval records of the seven collected meteorological parameters (wind direction, wind speed, wind gust, temperature, barometric pressure, relative humidity, and rainfall). The expected range for each parameter is presented in table 3 . The expected range for each parameter was determined based on the range of values within the 2007 through 2010 datasets (Draut and others, 2009a, 2009b, 2010b; Dealy and others, 2014) and on historical maximum and minimum values published by the NOAA National Climatic Data Center (NCDC) for Page, Arizona (station GHCND:USW00053164), Paria Point, Arizona (station GHCND:USR0000APAR), and Phantom Ranch, Arizona (station GHCND:USC00026471).

To identify potentially spurious data within the expected range of parameter values, deviations from natural trends were identified by graphical analysis. Graphical analysis was conducted by plotting values within Microsoft ${ }^{\circledR}$ Excel and Matlab ${ }^{\mathrm{TM}}$ R2013b. Records with values that deviated from diurnal, nocturnal, or seasonal trends were inspected to examine whether they represented real phenomena or were likely spurious data. Comparative analysis was conducted on parameters, such as rainfall, that do not necessarily follow daily or monthly trends. This analysis involved comparisons of graphical and tabular data for each weather station and the nearest upstream and downstream sites. Records with potentially spurious data were further inspected. Determination, justification, and rectification of anomalies have been included in appendix 2 .

\section{Results}

Meteorological data collected by GCMRC at each of the 14 automated weather stations within the Colorado River Corridor for the reporting period are provided in appendix 3. Appendix 3 contains 4-minute interval data for each of the automated weather stations, tab separated by parameter (wind direction, wind speed, wind gusts, air temperature, relative humidity, barometric pressure, and rainfall. In addition to the data collected during the reporting period, appendix 4 provides, for the first time in digital format, previously reported 4-minute interval data collected by the automated weather stations from February 2007 through December 2010.

A summary of meteorological data presented in appendix 3 is provided graphically in time-series plots in figures 3-9. Figure 3 presents mean wind speed and maximum wind gusts by wind direction. Mean and maximum wind speeds are affected by the frequency of wind direction change. For comparison, the number (frequency) of 4-minute records used to calculate these statistics was included, by azimuth, in the time-series plot as well as wind vector sums. Wind vector sums were calculated for winds greater than $2 \mathrm{~m} / \mathrm{s}$, a minimum threshold for sand transport (Draut and others, 2009a, 2009b, 2010b; Dealy and others, 2014). Time-series plots in figure 3 are presented by season based on typical solstice/equinox dates and the available data recorded. For 2011, winter was defined as from January 1 (first record) to March 20, spring was from March 20 to June 21, summer was from June 21 to September 22, and fall was from September 22 to November 22 (last record). For 2013, spring was defined as from April 27 (first record) to June 21, summer was from June 21 to September 22, fall was from September 22 to December 21, and winter was from December 21 to December 31 (last record). 
As gaps within the seasonal data were present, the percentage of data used for the wind speed-direction polar plots has been included in the figure description. Figures 4-8 present maximum wind gusts and mean wind speed, air temperature, relative humidity, and barometric pressure summarized by daily and nightly values. Daily 12-hour summary values were derived from parameters collected between 6 a.m. (0600) and 6 p.m. (1800), and nightly 12-hour summary values were derived from parameters collected between 6 p.m. (1800) and 6 a.m. (0600). Figure 9 presents cumulative daily rain totals with the maximum daily 10-minute rainfall intensity, a metric for precipitation-induced erosion (Collins and others, in press). Values for 10-minute intensity (in millimeters per hour) were calculated from the 4minute interval rainfall data using the following equation adapted from Ward and Elliot (1995):

$$
I=\left(r_{1}+r_{2}+\frac{r_{3}}{2}\right) * 6
$$

Where $r_{1}, r_{2}$, and $r_{3}$ are consecutive 4-minute intervals of total rainfall, in millimeters. A summary of the daily rainfall totals for the reporting period is provided in table 4 .

Table 4. Rainfall totals for the reporting period in millimeters per day.

[Table 4 is a Microsoft ${ }^{\mathbb{B}}$ Excel file available for download at $\left.h t t p: / / p u b s . u s g s . g o v / o f / 2014 / 1247\right]$

\section{Discussion and Meteorological Context}

Weather conditions during the reporting period are expected to be atypical because regional weather patterns in the Southwestern United States were warmer and drier than average (National Oceanic and Atmospheric Administration National Climatic Data Center, 2011, 2012, 2013). In 2011, much of the Southern United States experienced some degree of drought. Below-average rainfall and above-average air temperatures during the monsoon season (July-October) contributed to local areas of severe to extreme drought in northern Arizona (National Oceanic and Atmospheric Administration National Climatic Data Center, 2011). These conditions persisted through much of 2012, with the Lower Colorado River Basin experiencing the 24th driest year on record (National Oceanic and Atmospheric Administration National Climatic Data Center, 2012). Monsoon season temperatures continued to be high through 2013, and precipitation totals during this season exceeded normal conditions (116-year average) (National Oceanic and Atmospheric Administration National Climatic Data Center, 2013). Above-average precipitation during the summer and fall of 2013 was sufficient to alleviate some, but not all, of the drought conditions within the Lower Colorado River Basin ( National Oceanic and Atmospheric Administration National Climatic Data Center, 2013, 2014). Based on the Palmer Hydrologic Drought Index, short-term analysis suggests drought conditions will persist into 2014 (National Oceanic and Atmospheric Administration National Climatic Data Center, 2014).

Oceanic temperature cycles in the Pacific known as El Niño/Southern Oscillation (ENSO) can have a role in weather conditions within the Southwestern United States (Kumar and Hoerling, 1998), particularly in strong El Nino (warm) years, where cool season precipitation is typically above average, and in strong La Niña (cool) years, where annual precipitation is typically below average (McPhaden and Others, 2006; Wolter and Timlin, 2011). During the reporting period, ENSO was likely a minor factor in regional weather because the Pacific Ocean was in a weak to neutral ENSO state (National Oceanic and Atmospheric Administration National Climatic Data Center, 2011, 2012). In 2011, a weak La Niña (cool) state was present for most of the year (National Oceanic and Atmospheric Administration National Climatic Data Center, 2011). By April 2012, the ENSO had transitioned to a neutral state, where it remained through 2013 (National Oceanic and Atmospheric Administration National Climatic Data Center, 2012, 2013). 


\section{References Cited}

Basara, J.B., Illston, B.G., Winnings, T.E., Jr., and Fiebrich, C.A., 2009, Evaluation of rainfall measurements from the WXT510 sensor for use in the Oklahoma City Micronet: The Open Atmospheric Science Journal, v. 3, p. 39-47.

Collins, B.D., Bedford, D.R., Corbett, S.C., Cronkite-Ratcliff, C., and Fairley, H.C., in press, Meteorologic and anthropogenic effects on archeological site change in Grand Canyon, ArizonaFluvial-aeolian interactions within a dam-controlled river corridor: Journal of Geophysical Research.

Dealy, T.P., Draut, A.E., and Fairley, H.C., 2014, 2010 weather and aeolian sand-transport data from the Colorado River corridor, Grand Canyon, Arizona: U.S. Geological Survey Open-File Report 2014$1135,90 \mathrm{p}$.

Draut, A.E., 2012, Effects of river regulation on aeolian landscapes, Colorado River, southwestern USA: Journal of Geophysical Research—Earth Surface, v. 117, F2, 22 p., doi:10.1029/2011JF002329.

Draut, A.E., and Rubin, D.M., 2005, Measurements of wind, aeolian, sand transport, and precipitation in the Colorado River corridor, Grand Canyon, Arizona-November 2003 to December 2004: U.S. Geological Survey Open-File Report 2005-1309, 70 p.

Draut, A.E., and Rubin, D.M., 2006, Measurements of wind, aeolian sand transport, and precipitation in the Colorado River corridor, Grand Canyon, Arizona_January 2005 to January 2006: U.S. Geological Survey Open-File Report 2006-1188, 88 p., http://pubs.usgs.gov/of/2006/1188/.

Draut, A. E., and D. M. Rubin (2008), The role of eolian sediment in the preservation of archeologic sites along the Colorado River corridor in Grand Canyon National Park, Arizona, U.S. Geological Survey Professional Paper 1756,71p.

Draut, A.E., Andrews, T., Fairley, H.C., and Brown, C.R., 2009a, 2007 weather and aeolian sandtransport data from the Colorado River corridor, Grand Canyon, Arizona: U.S. Geological Survey Open-File Report 2009-1095, 110 p.

Draut, A.E., Sondossi, H.A., Hazel, J.E., Jr., Andrews, T., Fairley, H.C., Brown, C.R., and Vanaman, K.M., 2009b, 2008 weather and aeolian sand-transport data from the Colorado River corridor, Grand Canyon, Arizona: U.S. Geological Survey Open-File Report 2009-1190, 98 p.

Draut, A.E., Hazel, J.E., Jr., Fairley, H.C., and Brown, C.R., 2010a, Aeolian reworking of sandbars from the March 2008 Glen Canyon Dam high flow experiment in Grand Canyon, in Melis, T.S., Hamill, J.F., Coggins, L.G., Jr., Grams, P.E., Kennedy, T.A., Kubly, D.M., and Ralston, B.E., eds., Proceedings of the Colorado River Basin Science and Resource Management Symposium, November 18-20, 2008, Scottsdale, Ariz.: U.S. Geological Survey Scientific Investigations Report 2010-5135, 325-331 p.

Draut, A.E., Sondossi, H.A., Dealy, T.P., Hazel, J.E., Jr., Fairley, H.C., and Brown, C.R., 2010b, 2009 weather and aeolian sand-transport data from the Colorado River corridor, Grand Canyon, Arizona: U.S. Geological Survey Open-File Report 2010-1166, 98 p.

Kumar, A., and M.P., Hoerling, 1998, Annual cycle of Pacific/North American seasonal predictability associated with different phases of ENSO: Journal of Climate, v. 11, p. 3,295-3,308 p.

Maus, S., Macmillan, S., McLean, S., Hamilton, B, Thomson, A., Nair, M., and Rollins, C., 2010, The US/UK World Magnetic Model for 2010-2015: National Oceanic and Atmospheric Administration, NOAA Technical Report NESDIS/NGDC.

McPhaden, M. J., Zebiak, S. E., and Glantz, M.H., 2006, ENSO as an integrating concept in Earth Science: Science, v. 314, 1,740-1,745 p.

National Oceanic and Atmospheric Administration National Weather Service, 2010, National Weather Service Instruction 10-1301: National Oceanic and Atmospheric Administration, http://www.nws.noaa.gov/directives/sym/pd01013001curr.pdf. 
National Oceanic and Atmospheric Administration National Climatic Data Center, 2011, State of the Climate-National Overview for Annual 2011: National Oceanic and Atmospheric Administration, http://www.ncdc.noaa.gov/sotc/national/2011/13.

National Oceanic and Atmospheric Administration National Climatic Data Center, 2012, State of the Climate-Drought for Annual 2012: National Oceanic and Atmospheric Administration, http://www.ncdc.noaa.gov/sotc/drought/2012/13.

National Oceanic and Atmospheric Administration National Climatic Data Center, 2013, State of the Climate-National Overview for Annual 2013: National Oceanic and Atmospheric Administration, http://www.ncdc.noaa.gov/sotc/national/2013/13.

National Oceanic and Atmospheric Administration National Climatic Data Center, 2014, State of the Climate-Drought for January 2014: National Oceanic and Atmospheric Administration, http://www.ncdc.noaa.gov/sotc/drought/2014/1.

Salmi, A., Lasse, E., Kopsala, P., and Laukkanen, E., 2008, Piezoelectric Vaisala Raincap ${ }^{\circledR}$ rain sensor applied to drop size distribution monitoring, Vaisala Technical Document, Helsinki, Finland.

Sankey, J.B., and Draut, A.E., 2014, Gully annealing by aeolian sediment-Field and remote-sensing investigation of aeolian-hillslope-fluvial interactions, Colorado River corridor, Arizona, USA: Geomorphology, v. 220, 68-80 p.

U.S. Department of the Interior, 1995, Operation of Glen Canyon Dam Final Environmental Statement: Salt Lake City, Utah, Bureau of Reclamation, Upper Colorado Region, Bureau of Reclamation, FES 95-98.

Vaisala, 2008, Vaisala weather transmitter WXT520: Vaisala User's Guide, 166 p.

Ward, A.D., and Elliot, W.J., 1995, Precipitation, in Ward, A.D., and Elliot, W.J., eds., Environmental hydrology: Boca Raton, Fl., CRC Press, 29-36 p.

Wauben, W.M.F., 2005, Wind tunnel and field test of three 2D sonic anemometers, Royal Netherlands Meteorological Institute Technical Report, De Bilt, Finland. http://www.knmi.nl/ wauben/Sensor/TECO2005_P3(17)_Wauben.pdf

Wolter, K., and Timlin, M.S., 2011, El Nino/Southern Oscillation behavior since 1871 as diagnosed in an extended multivariate ENSO index (MEI.ext): International Journal of Climatology, v. 31, p. 1,074-1,087. 
This page left intentionally blank 
Figure 3. Polar plots showing seasonal wind speed means, maximum wind gusts, wind vector sums for wind speeds greater than 2 meters per second, and the total number (frequency) of 4-minute records by azimuth (in respect to true north).

Seasonal statistics were calculated for 2011 based on the following dates-winter from January 1 (first record) to March 20 (28,440 possible records), spring from March 20 to June 21 (33,480 possible records), summer from June 21 to September 22 (33,480 possible records), and fall from September 22 to November 22 (last record) (21,746 possible records). Seasonal statistics were calculated for 2013 based on the following dates - spring was from April 27 (first record) to June 21 (33,480 possible records), summer from June 21 to September 22 (33,480 possible records), fall from September 22 to December 21 (32,400 possible records), and winter from December 21-December 31 (last record) (3,600 possible records). Data were not collected between November 22, 2011, and April 27, 2013. All polar plots represent the maximum number of possible 4minute records unless otherwise stated. 
2011

No Data Recorded in 2011

No Data Recorded in 2011

No Data Recorded in 2011

No Data Recorded in 2011

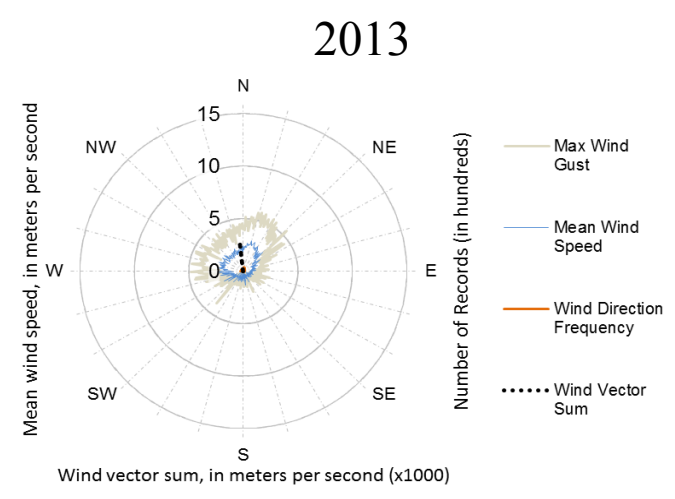

No Data Recorded in 2013

No Data Recorded in 2013

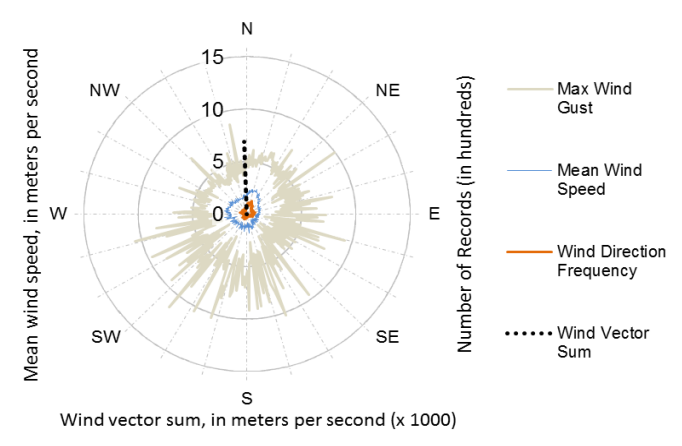

Figure 3. (a) Station AZ C:02:0071 seasonal wind speed-direction plots. In 2013, 52 percent of the possible records were collected during fall 
2011

No Data Recorded in 2011

No Data Recorded in 2011

No Data Recorded in 2011

No Data Recorded in 2011
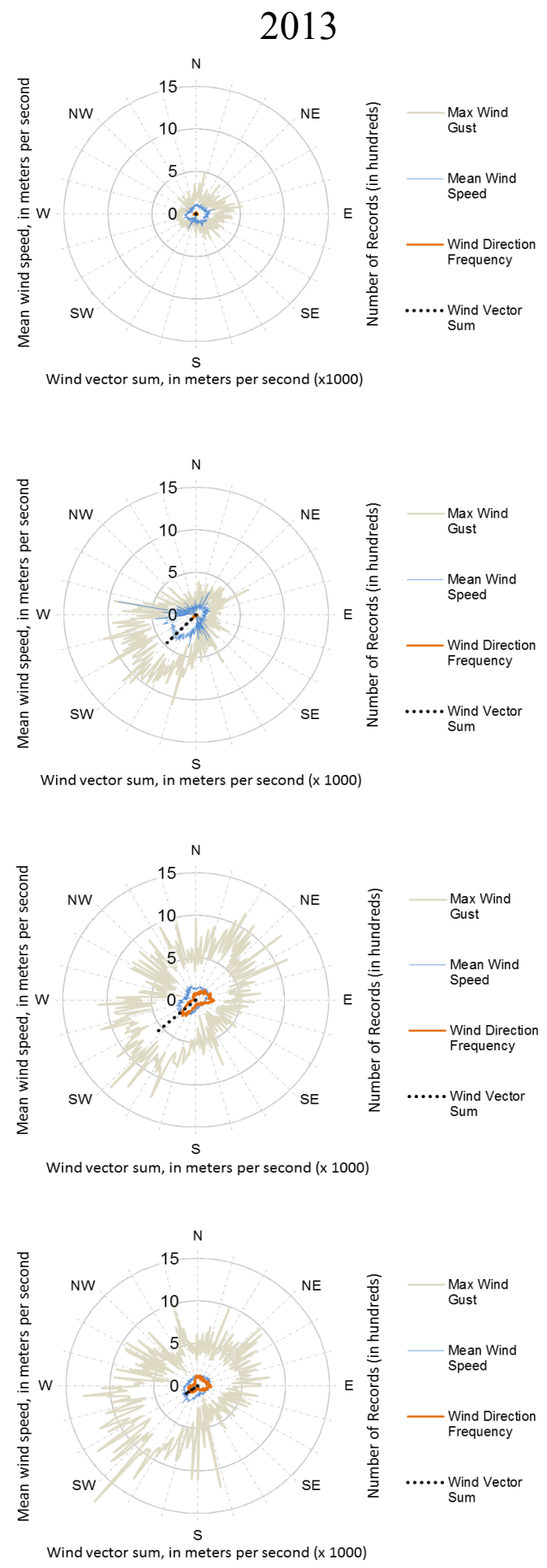

Figure 3. (b) Station AZ C:02:0070 seasonal wind speed-direction plots. In 2013, 17 percent of the possible records were collected during spring and 89 percent were collected during winter. 
2011

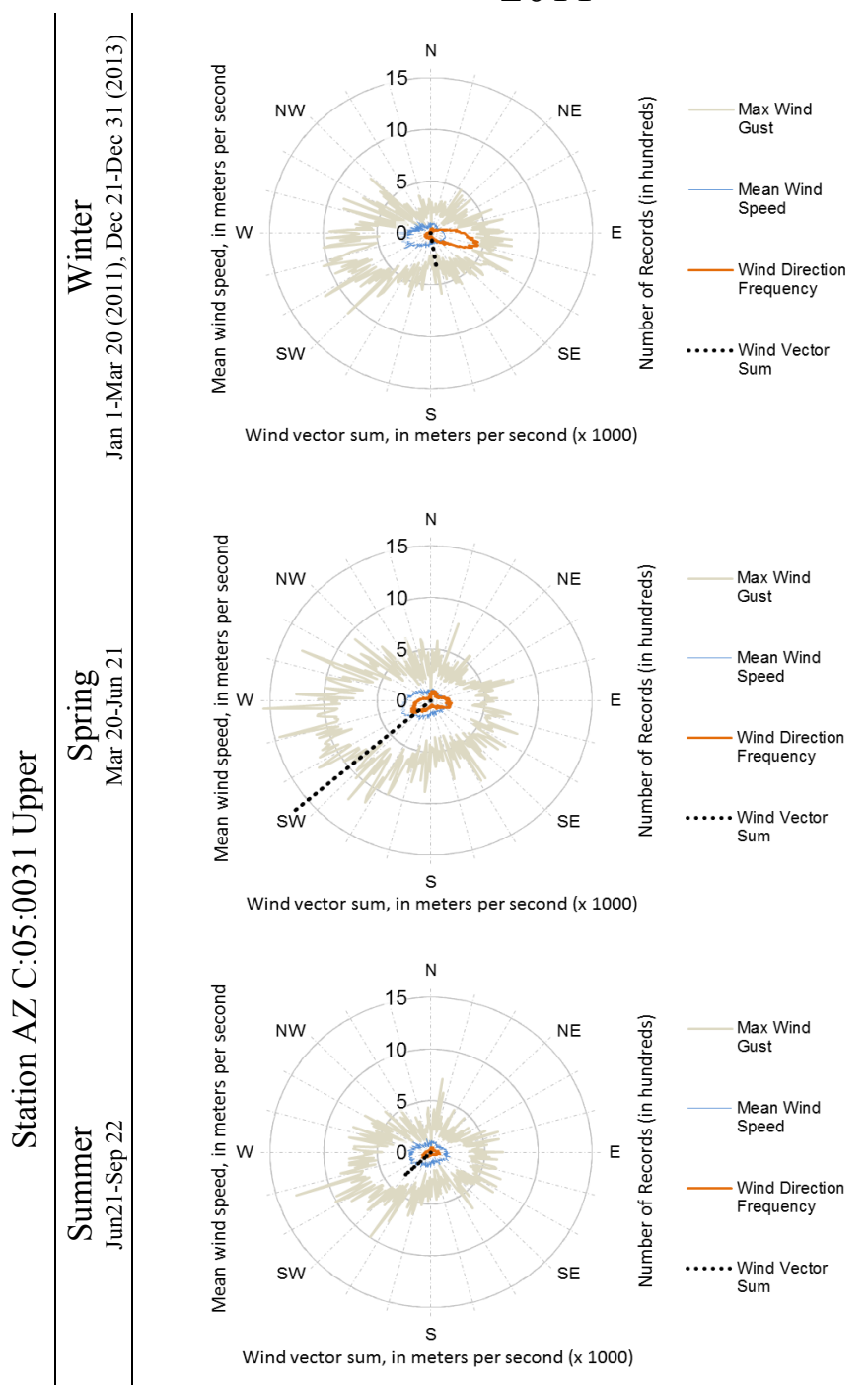

No Data Recorded in 2011
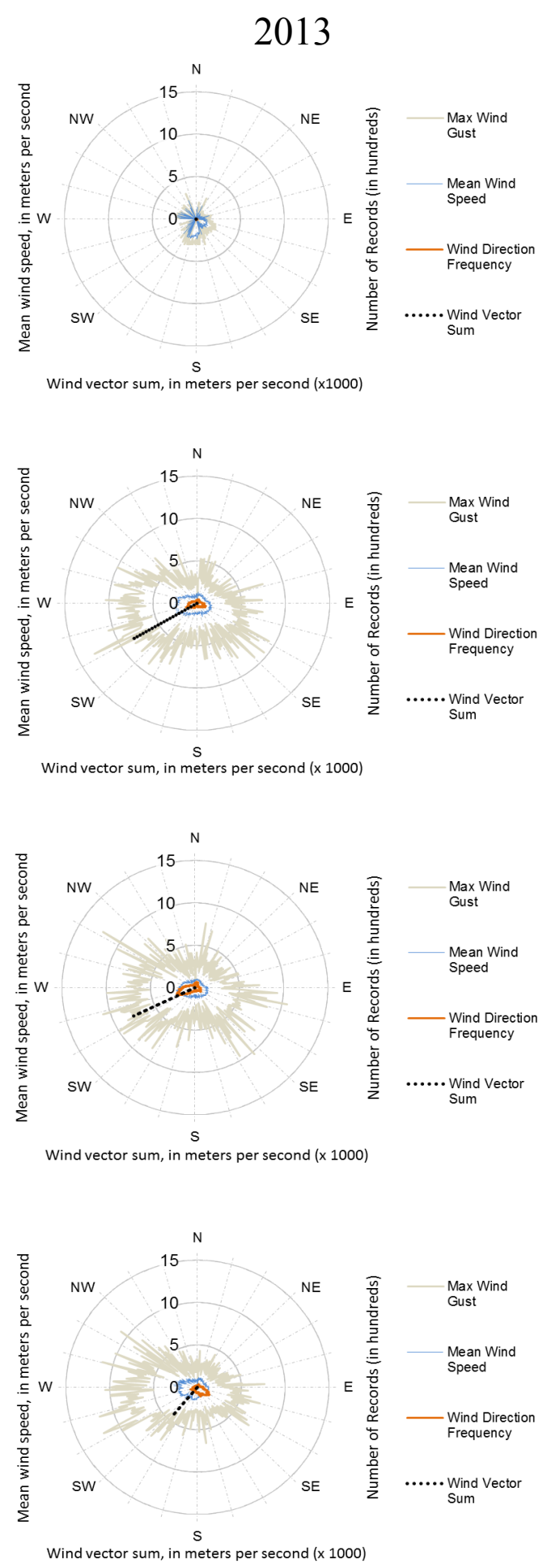

Figure 3. (c) Station AZ C:05:0031 Upper seasonal wind speed-direction plots. In 2011, 40 percent of the possible records were collected during summer. In 2013, 20 percent of the possible records were collected during winter, 92 percent were collected during spring, 68 percent were collected during summer, and 57 percent were collected during fall. 


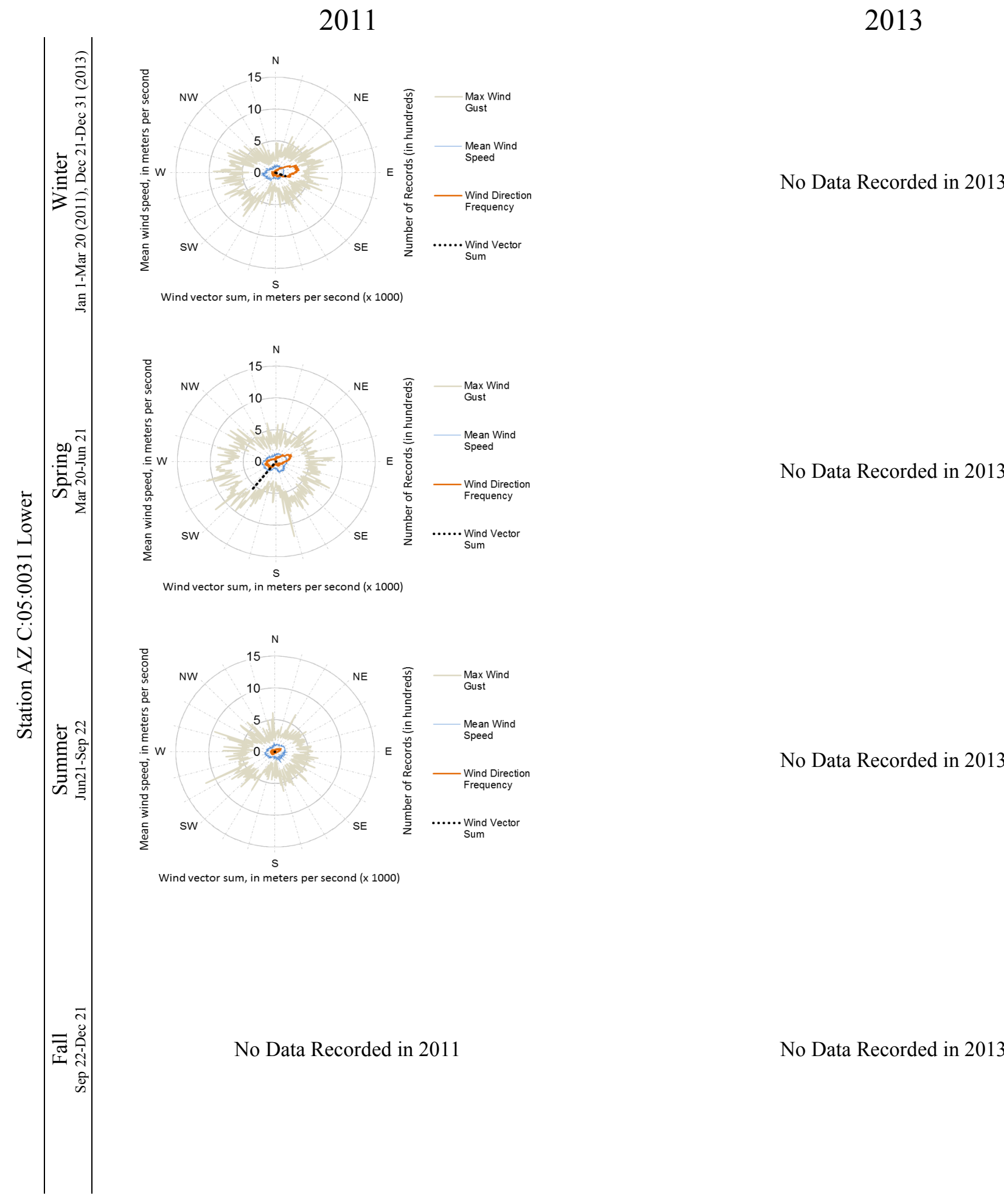

Figure 3. (d) Station AZ C:05:0031 Lower seasonal wind speed-direction plots. In 2011, 40 percent of the possible records were collected during summer. 


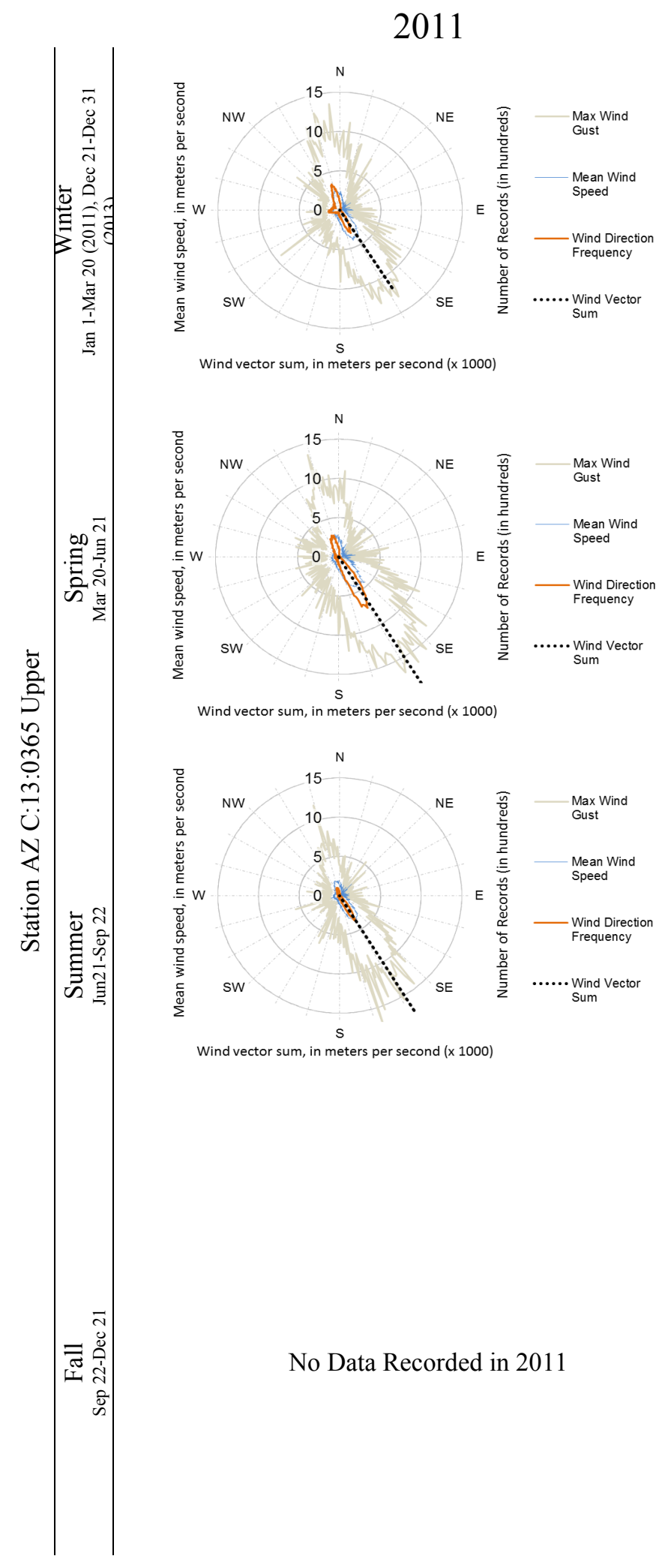

No Data Recorded in 2013

No Data Recorded in 2013

No Data Recorded in 2013

No Data Recorded in 2013

Figure 3. (e) Station AZ C:13:0365 Upper seasonal wind speed-direction plots. In 2011, 42 percent of the possible records were collected during summer. 


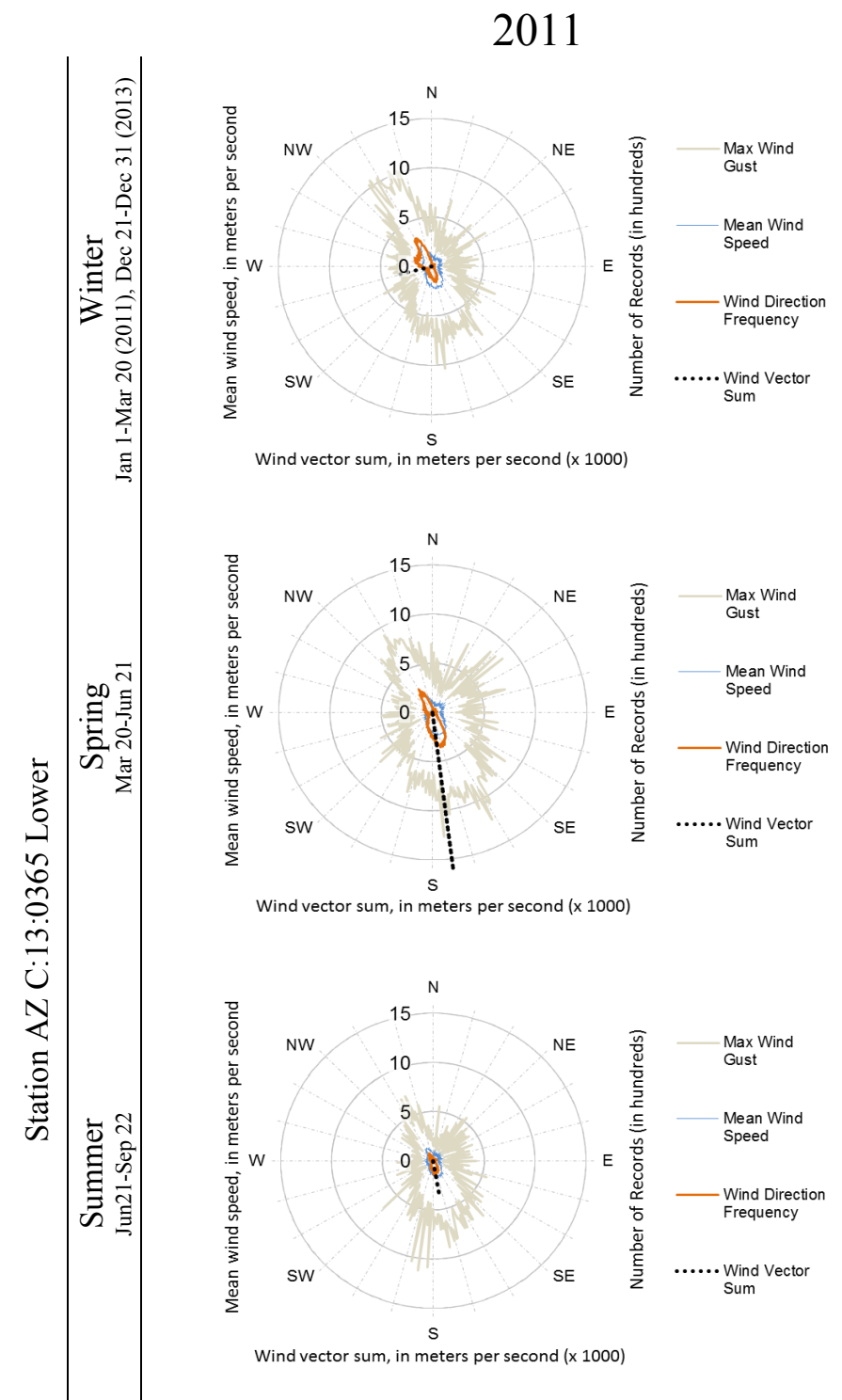

No Data Recorded in 2013

No Data Recorded in 2013

No Data Recorded in 2013

No Data Recorded in 2011

No Data Recorded in 2013

Figure 3. (f) Station AZ C:13:0365 Lower seasonal wind speed-direction plots. In 2011, 42 percent of the possible records were collected during summer. 


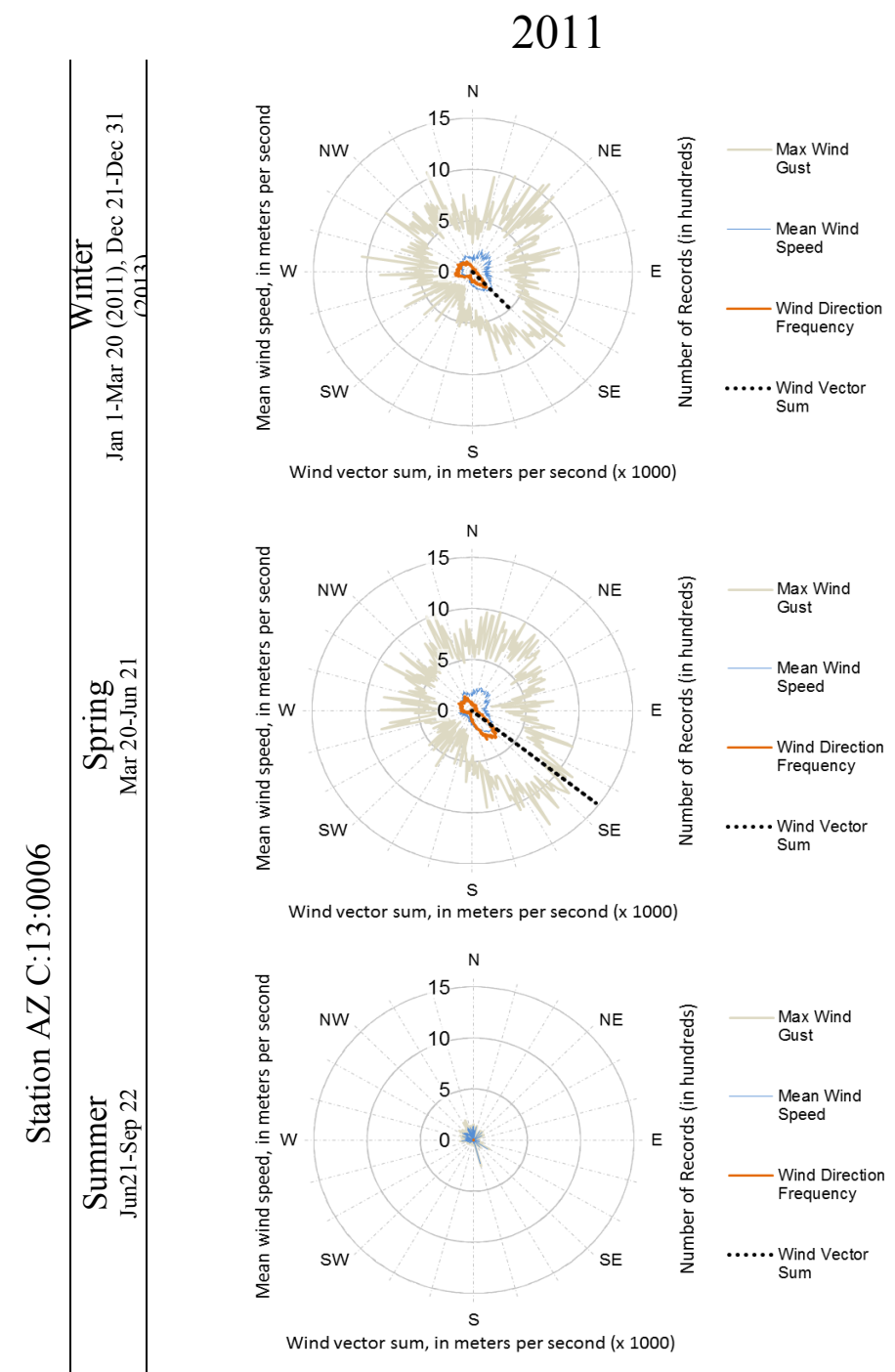

No Data Recorded in 2011
2013

No Data Recorded in 2013

No Data Recorded in 2013

No Data Recorded in 2013

No Data Recorded in 2013

Figure 3. (g) Station AZ C:13:0006 seasonal wind speed-direction plots. In 2011, 4 percent of the possible records were collected during summer. 


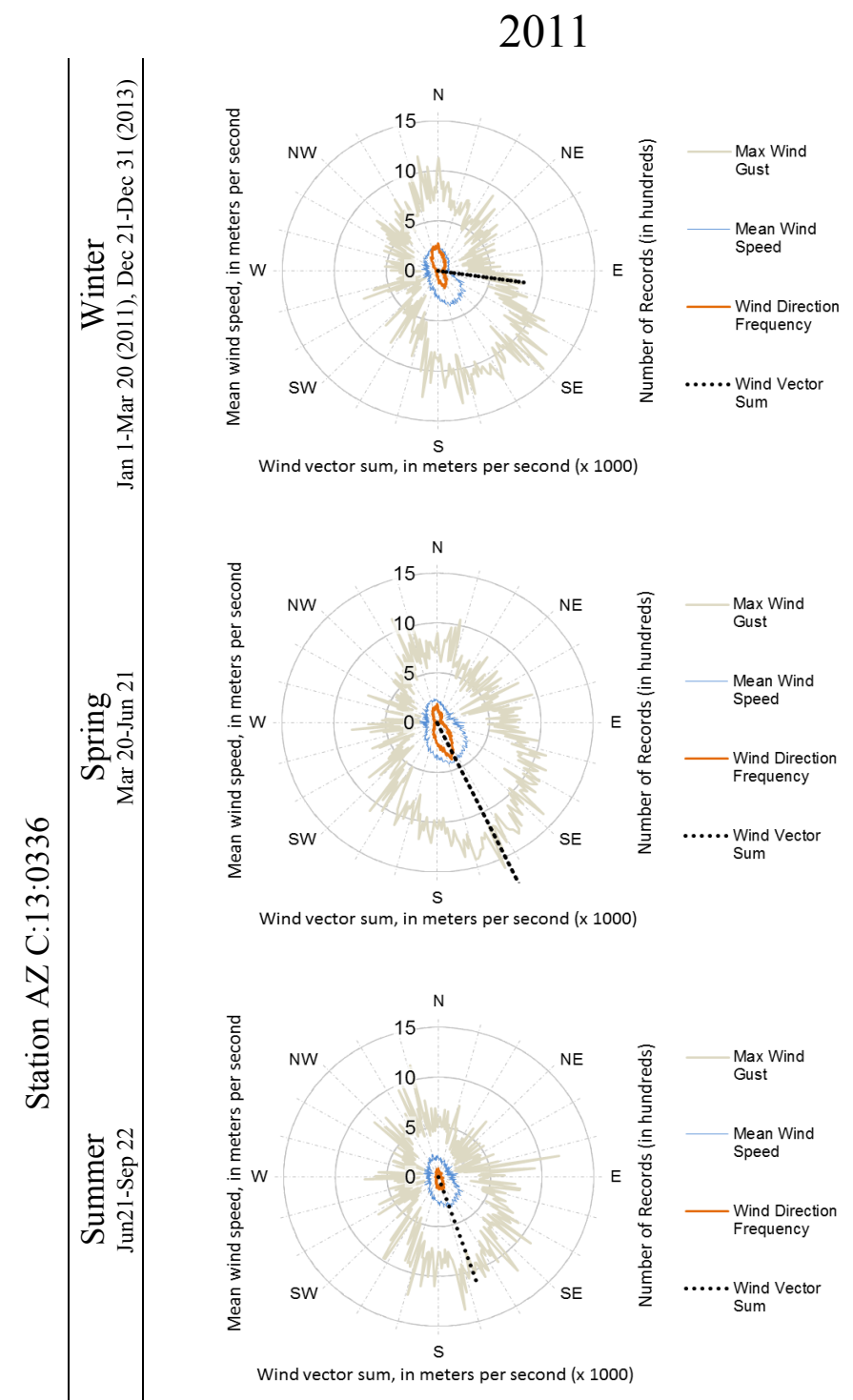

No Data Recorded in 2011
2013

No Data Recorded in 2013

No Data Recorded in 2013

No Data Recorded in 2013

No Data Recorded in 2013

Figure 3. (h) Station AZ C:13:0336 seasonal wind speed-direction plots. In 2011, 45 percent of the possible records were collected during summer. 
2011

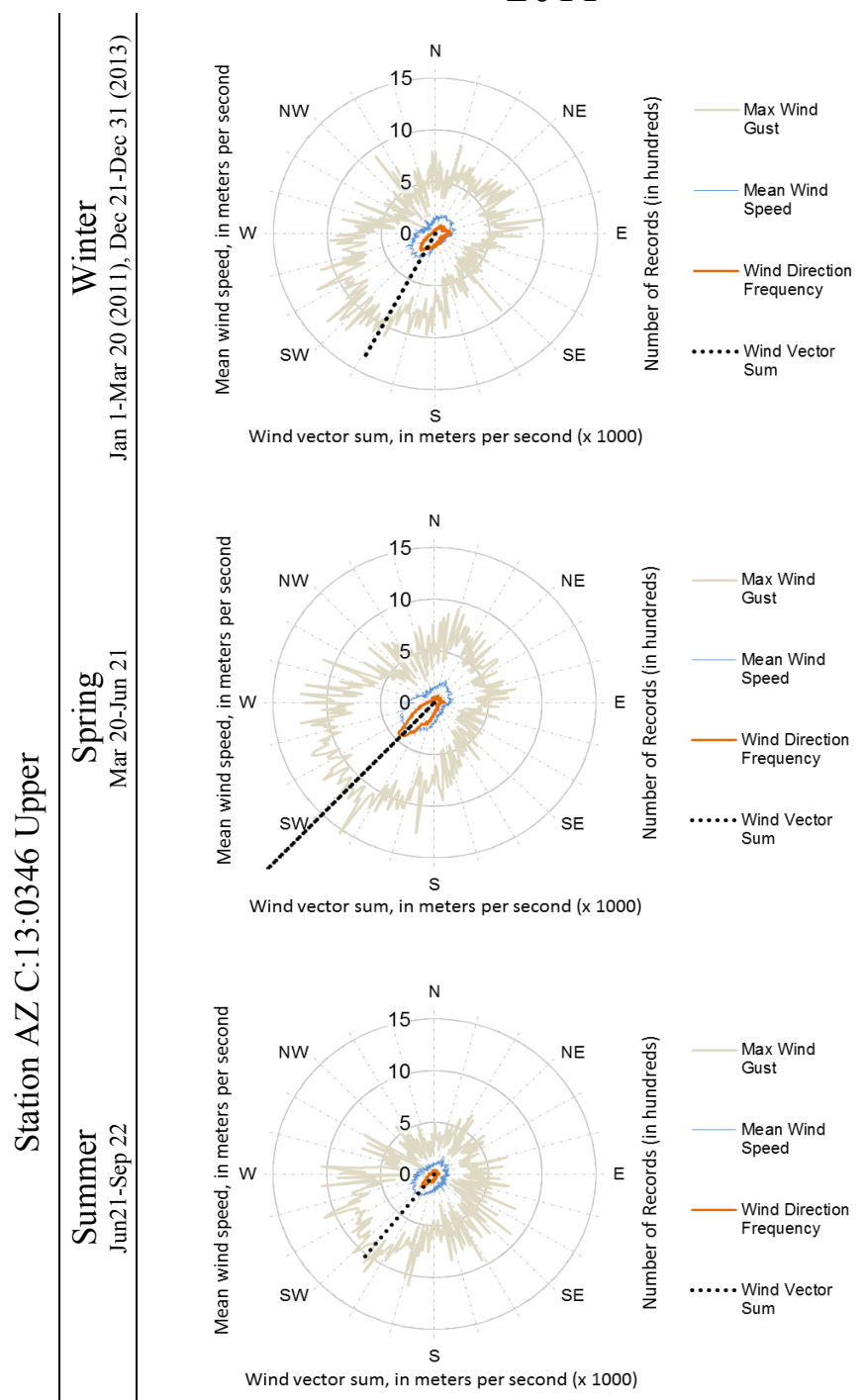

No Data Recorded in 2011
2013
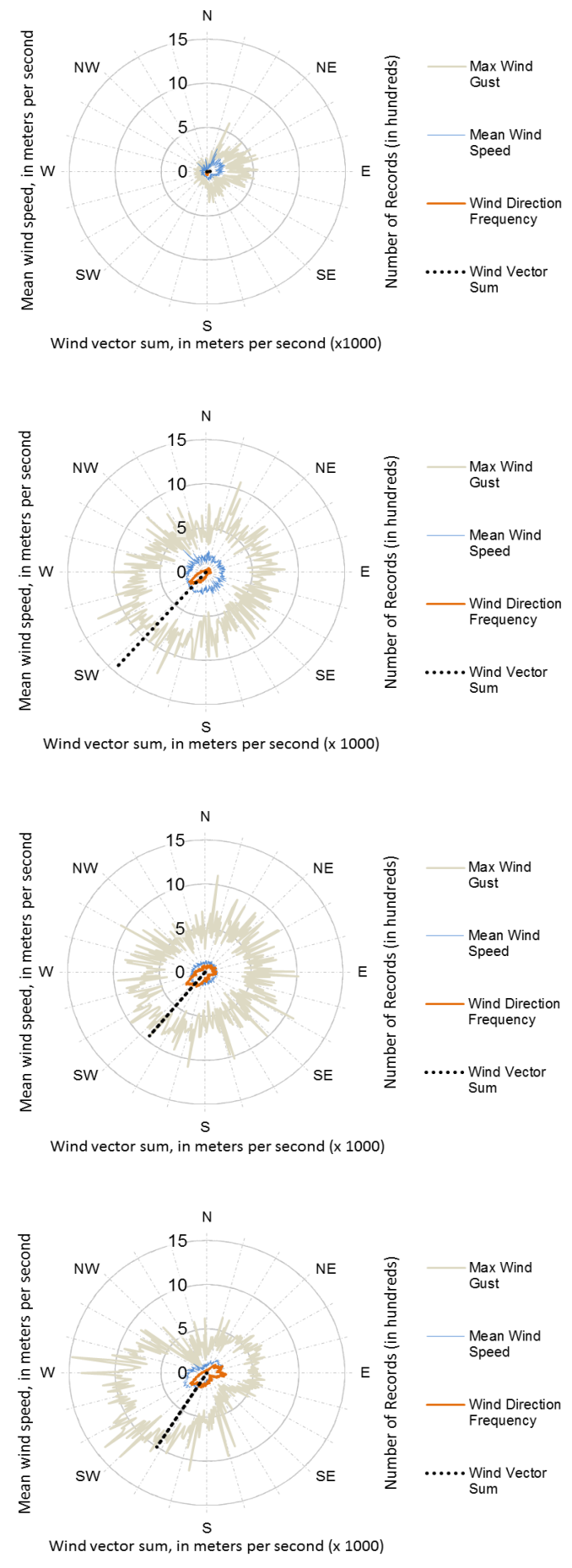

Figure 3. (i) Station AZ C:13:0346 Upper seasonal wind speed-direction plots. In 2011, 45 percent of the possible records were collected during summer. In 2013, 92 percent of the possible records were collected during spring. 


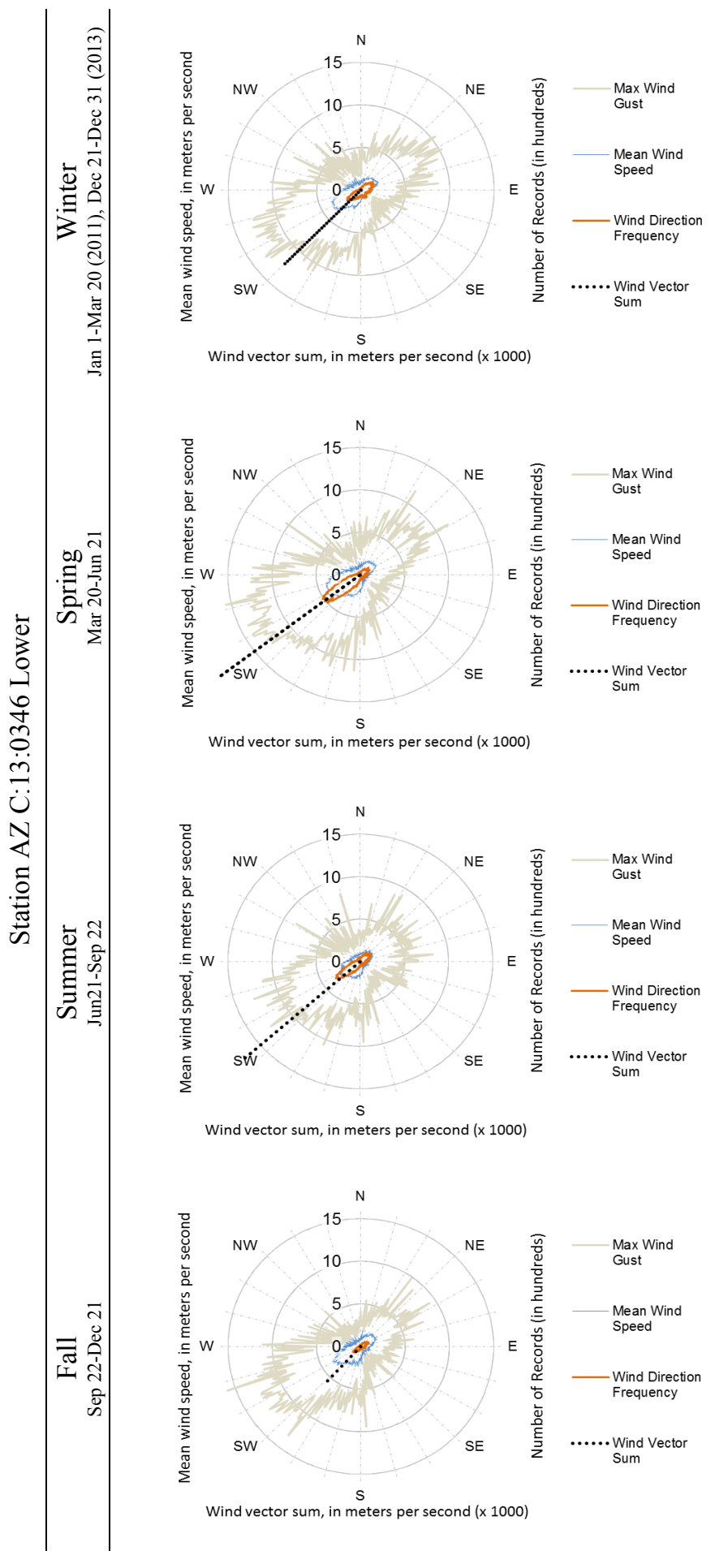

No Data Recorded in 2013

No Data Recorded in 2013

No Data Recorded in 2013

No Data Recorded in 2013

Figure 3. (j) Station AZ C:13:0346 Lower seasonal wind speed-direction plots. In 2011, 94 percent of the possible records were collected during winter, 99 percent were collected during spring, 89 percent were collected during summer, and 61 percent were collected during fall. 
No Data Recorded in 2011

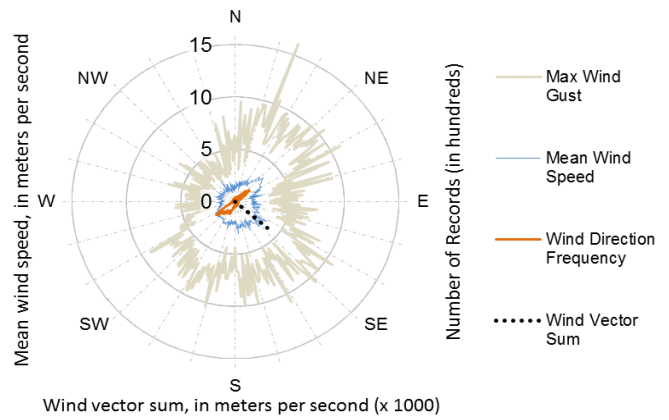

No Data Recorded in 2011

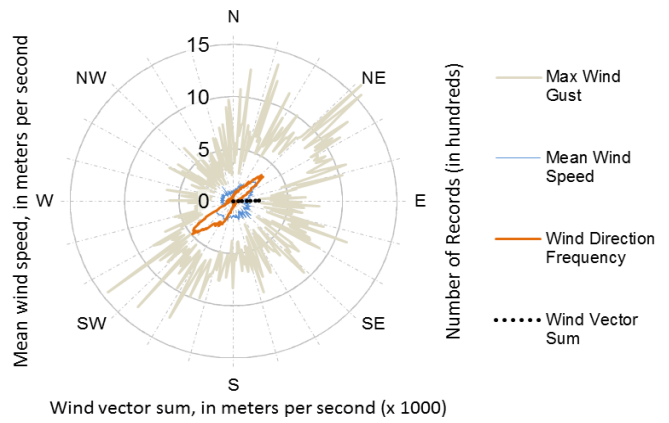

No Data Recorded in 2011

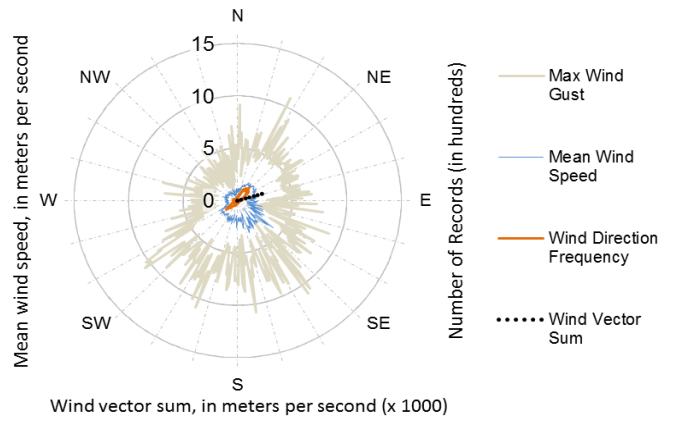

Figure 3. (k) Station AZ B:10:0225 seasonal wind speed-direction plots. In 2013, 83 percent of the possible records were collected during spring and 44 percent were collected during fall. 


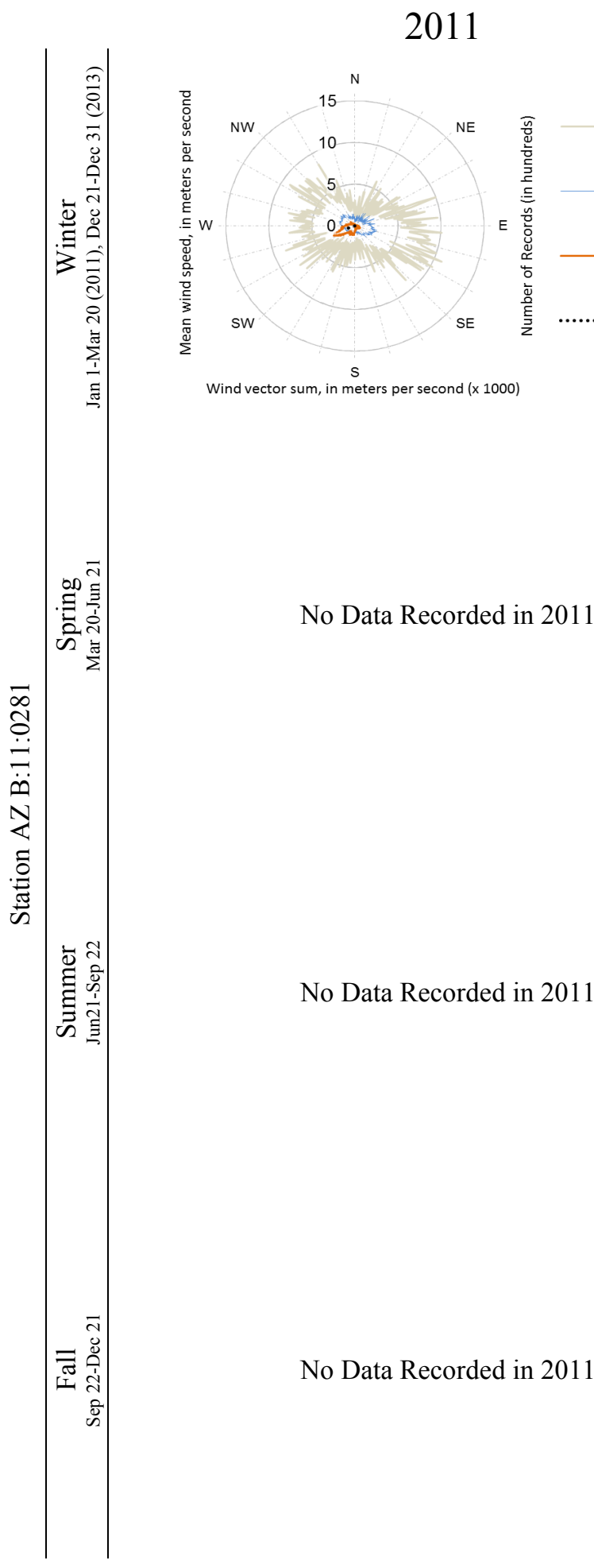

No Data Recorded in 2013

No Data Recorded in 2013

No Data Recorded in 2013

Figure 3. (I) Station AZ B:11:0281 seasonal wind speed-direction plots. In 2011, 73 percent of the possible records were collected during winter. 


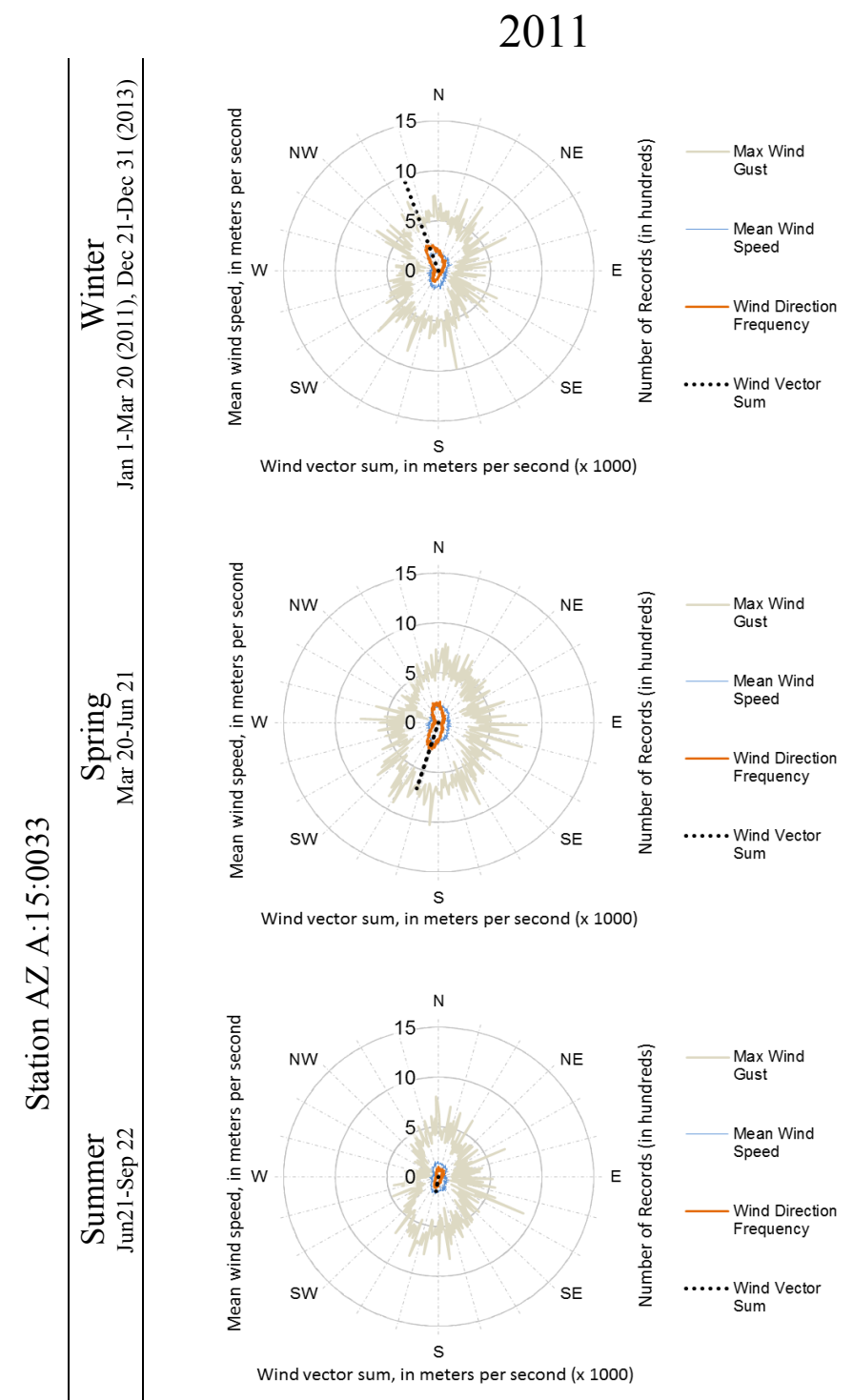

No Data Recorded in 2011
2013

No Data Recorded in 2013

No Data Recorded in 2013

No Data Recorded in 2013

No Data Recorded in 2013

Figure 3. (m) Station AZ A:15:0033 seasonal wind speed-direction plots. In 2011, 49 percent of the possible records were collected during summer. 


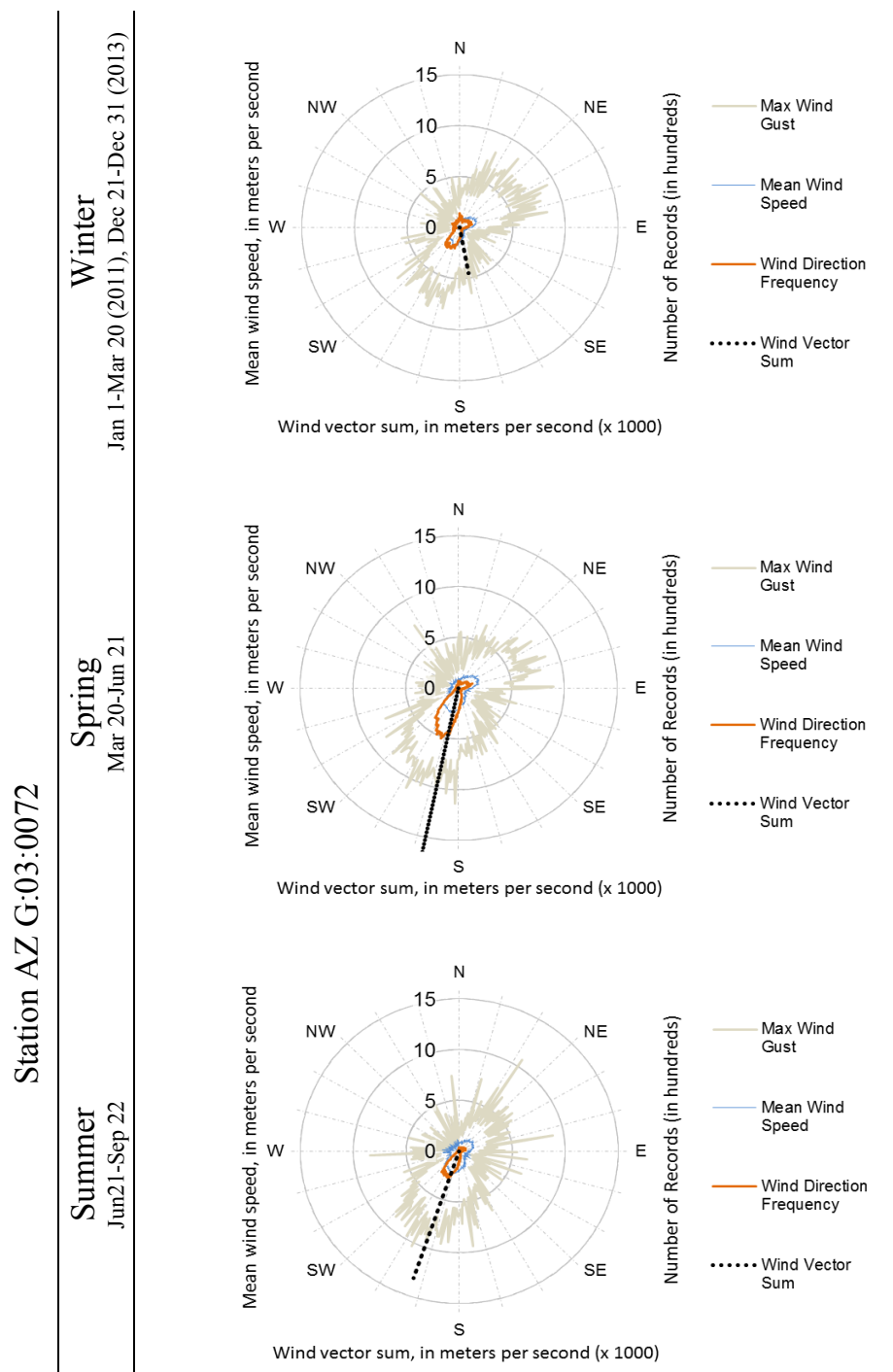

No Data Recorded in 2013
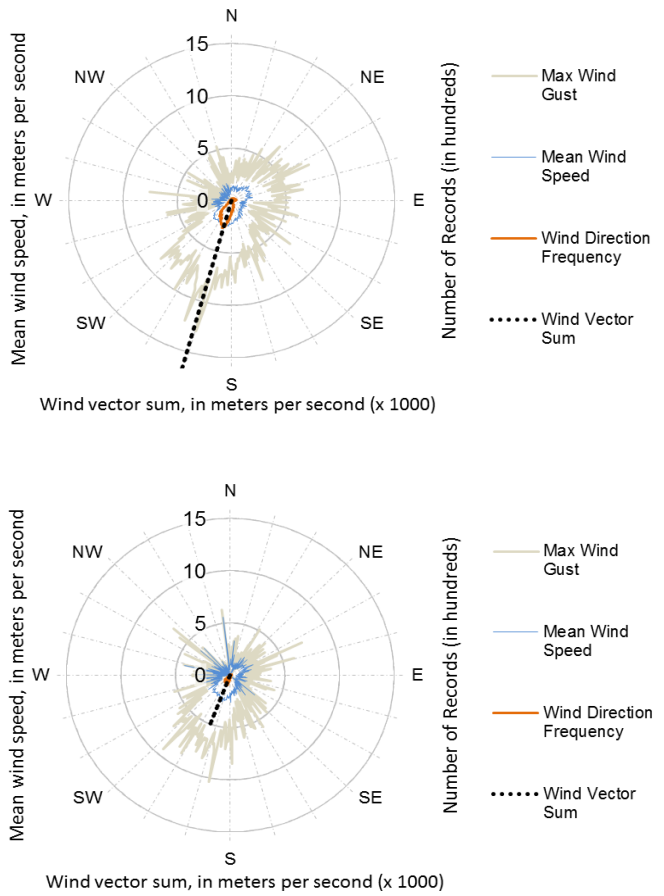

No Data Recorded in 2011

No Data Recorded in 2013

Figure 3. (n) Station AZ G:03:0072 seasonal wind speed-direction plots. In 2011, 54 percent of the possible records were collected during summer. In 2013, 75 percent of the possible records were collected during spring and 15 percent were collected during summer. 
No Data Collected in 2011

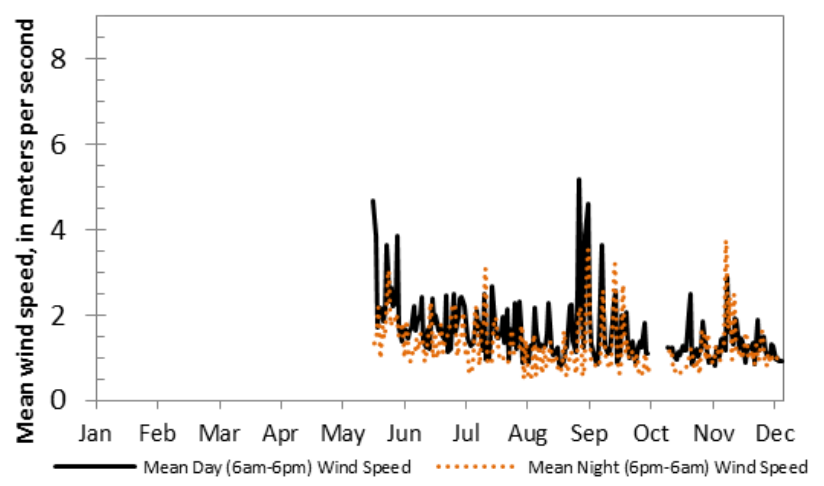

No Data Collected in 2011
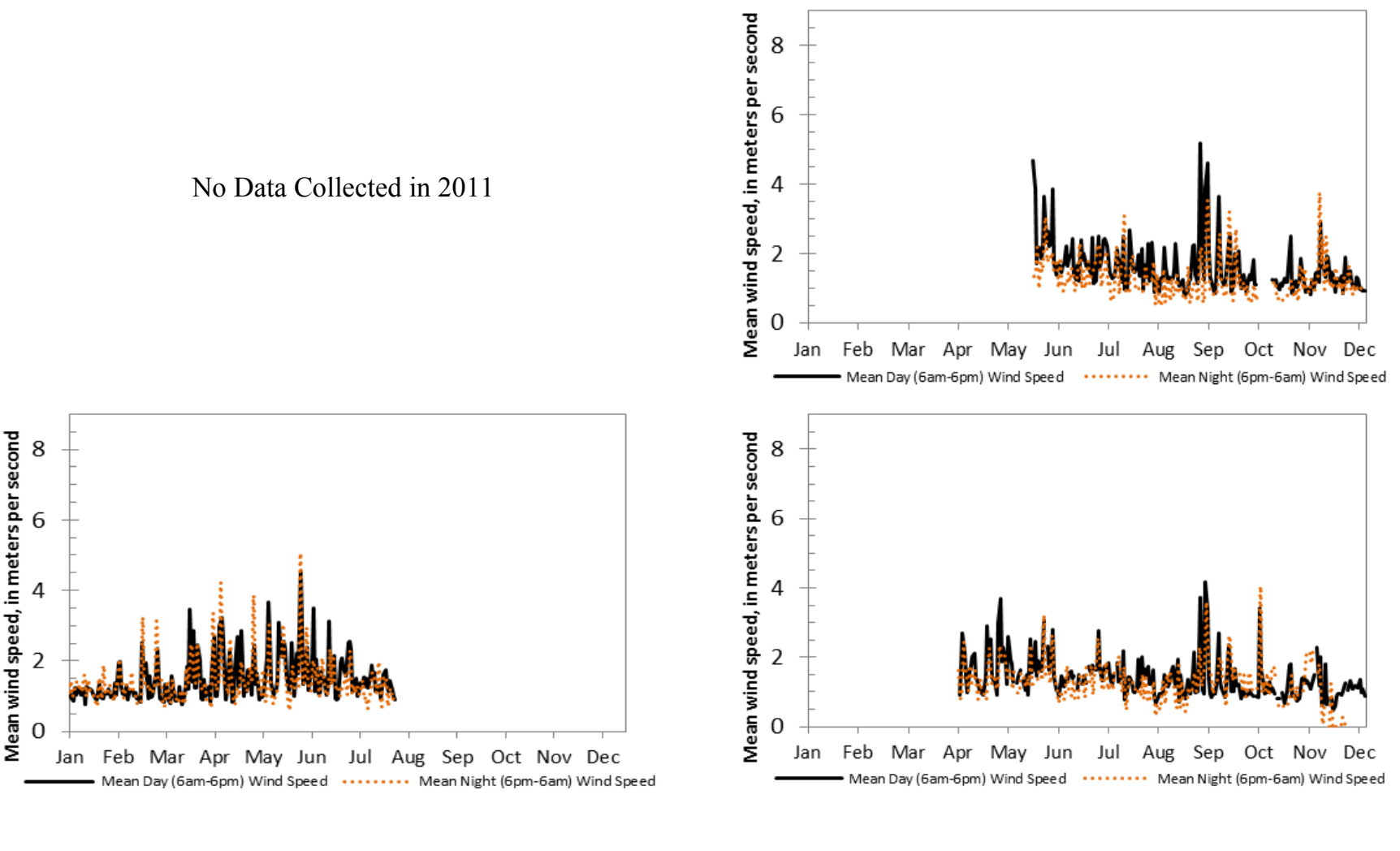

Figure 4. Graphs showing mean wind speeds recorded for 12-hour day (6 a.m.-6 p.m.) and night (6 p.m.-6 a.m.), January 1 , 2011, through December 31, 2013. Data were not collected between November 22, 2011, and April 27, 2013. 


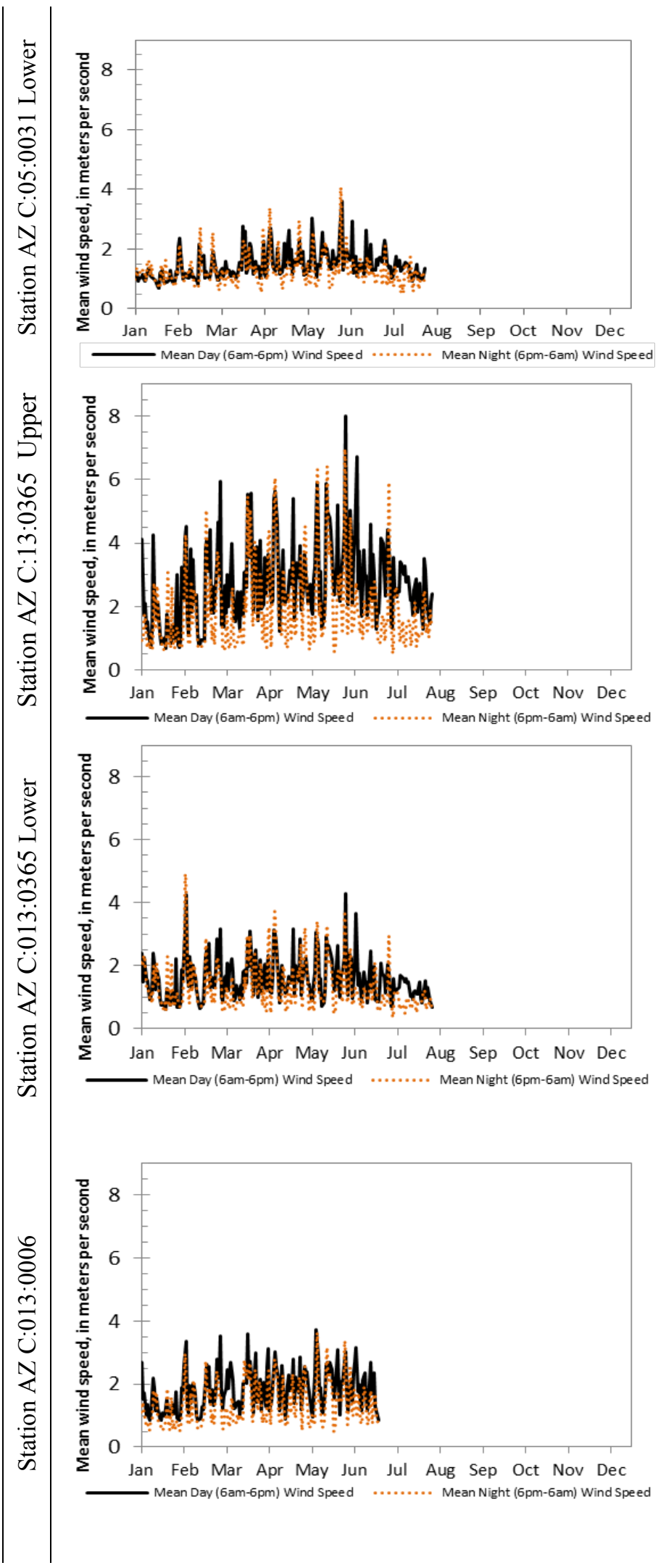

No Data Collected in 2013

No Data Collected in 2013

No Data Collected in 2013

No Data Collected in 2013

Figure 4.-Continued 


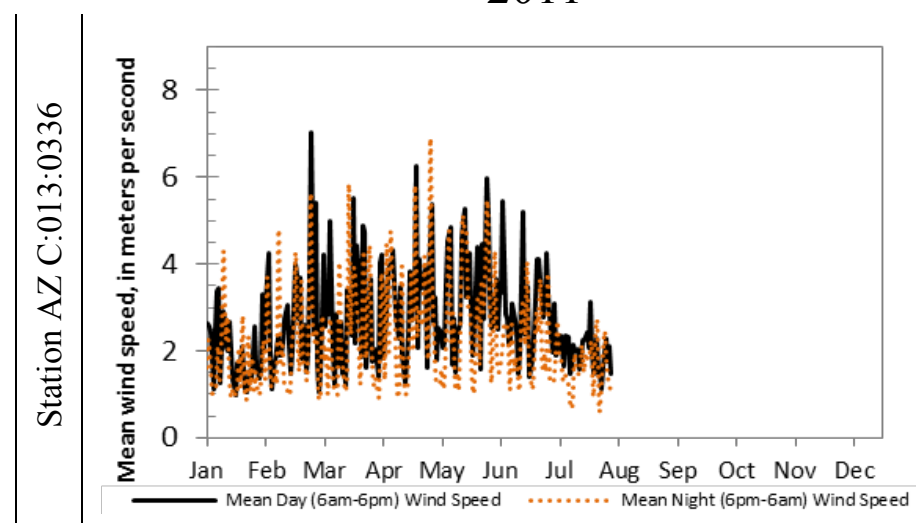

No Data Collected in 2013
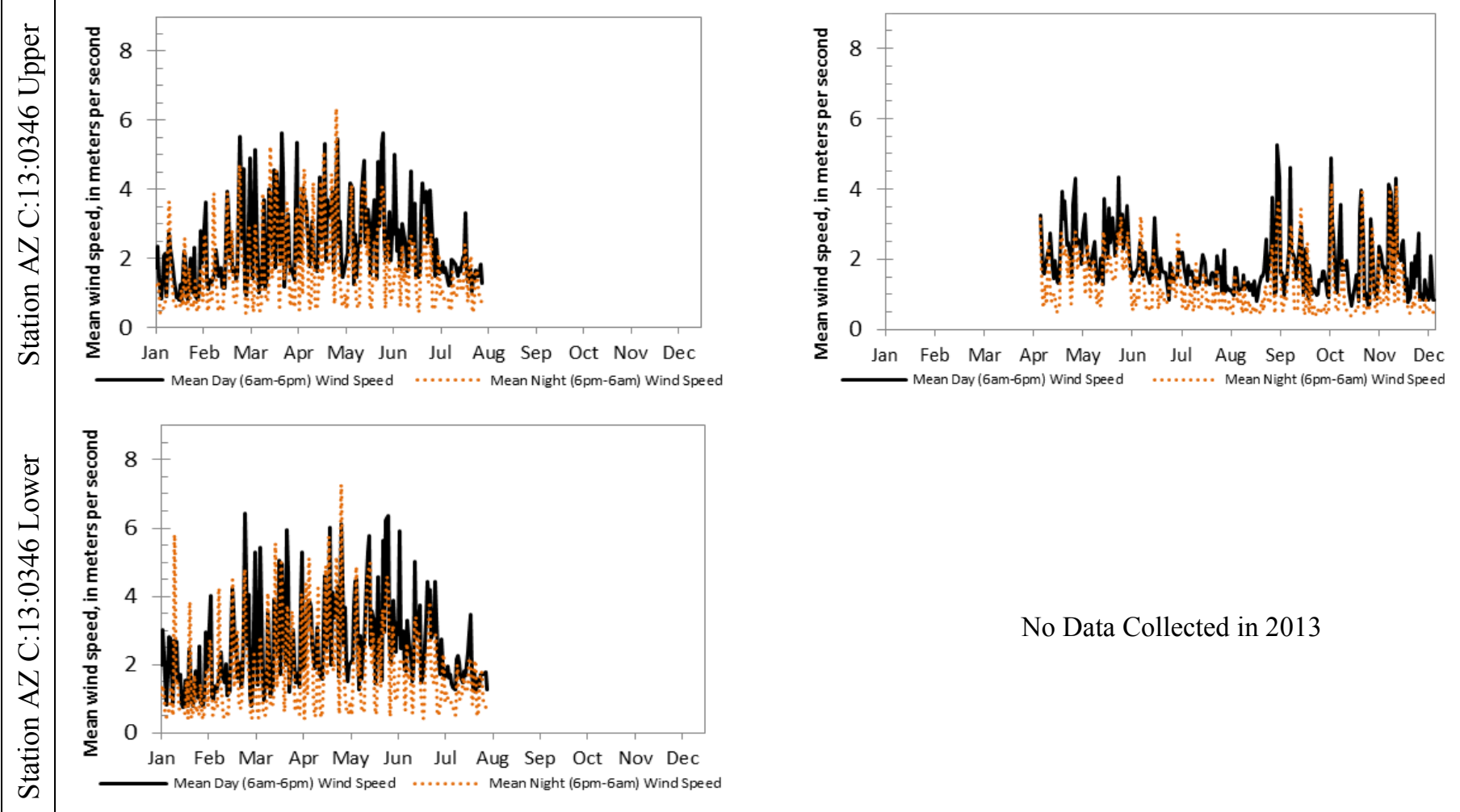

No Data Collected in 2011

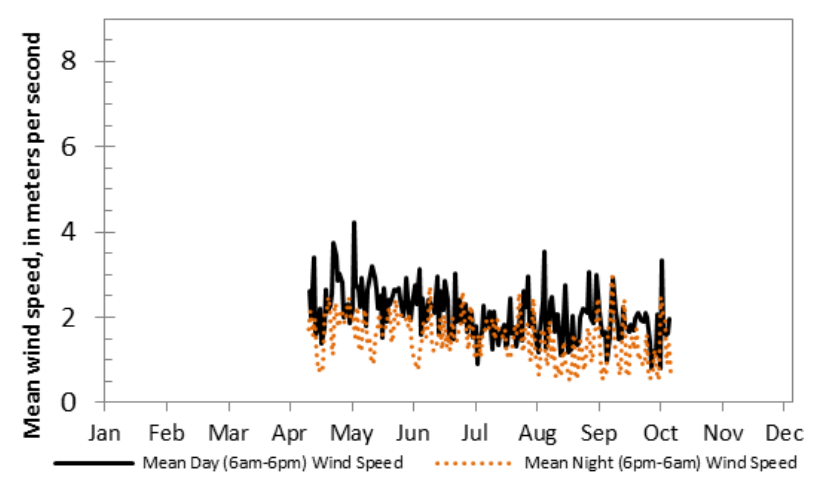

Figure 4.-Continued 

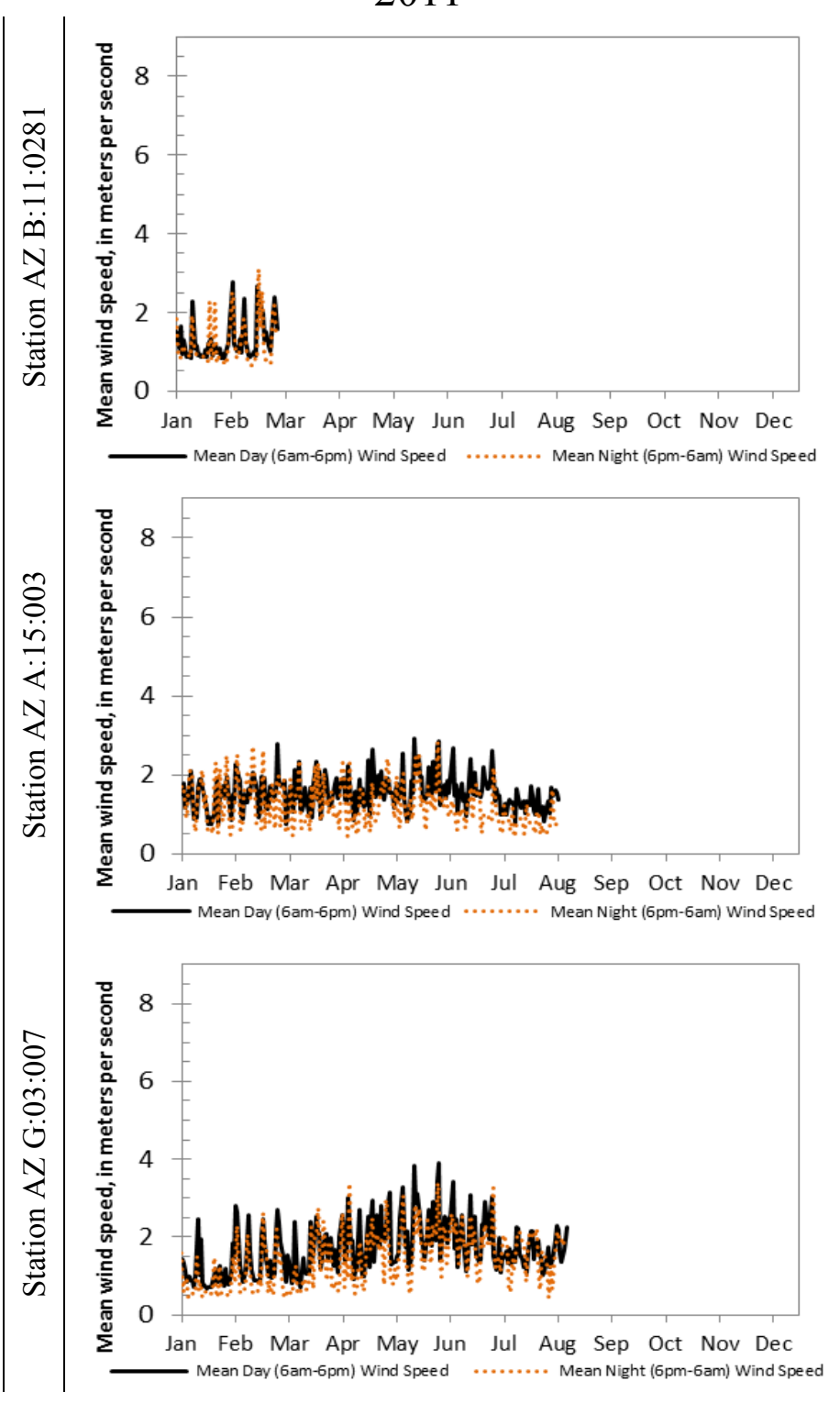

Figure 4.-Continued
No Data Collected in 2013

No Data Collected in 2013

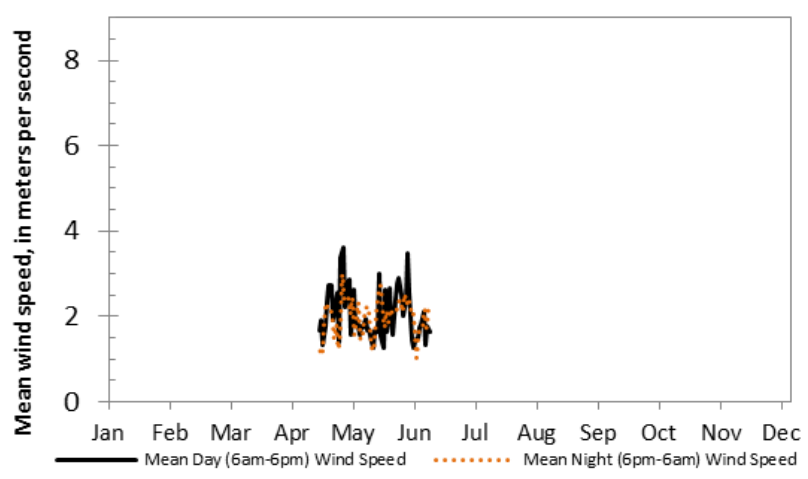


No Data Collected in 2011

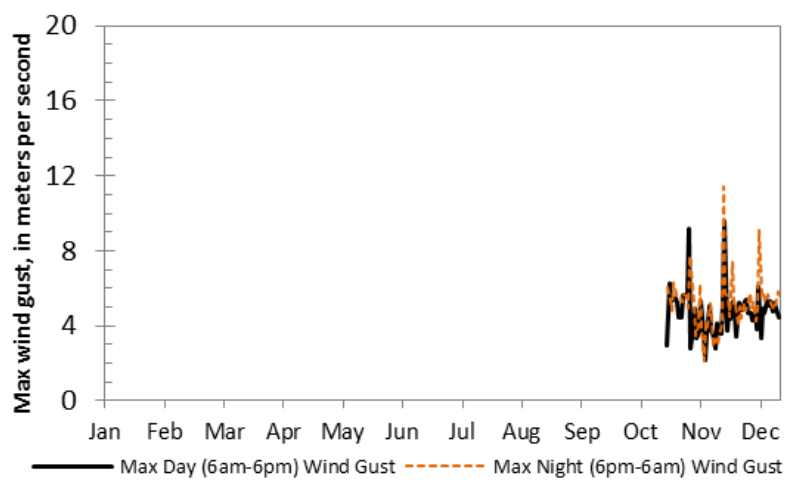

No Data Collected in 2011
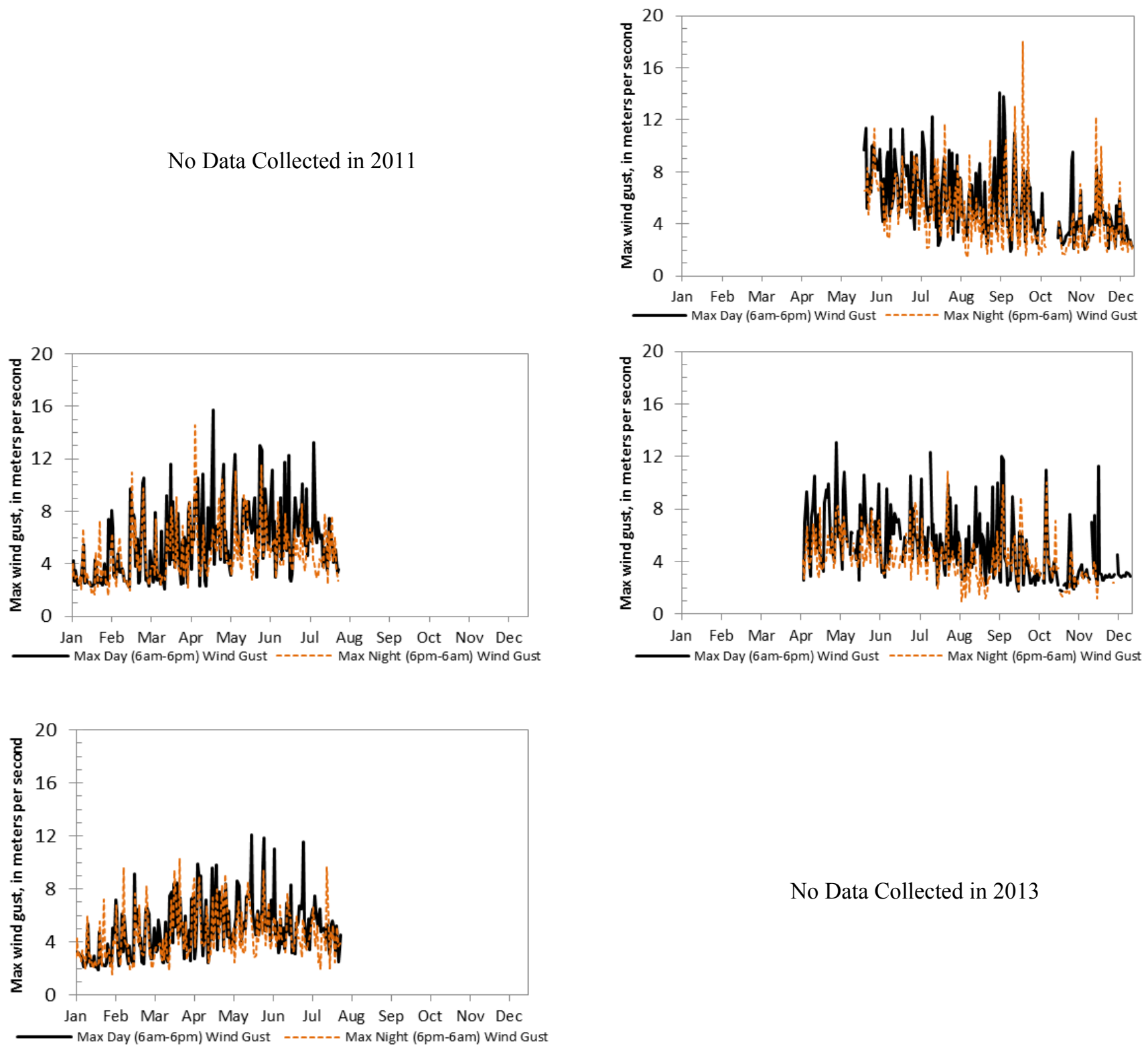

No Data Collected in 2013

Figure 5. Graphs showing maximum wind gusts recorded for 12 -hour day (6 a.m.-6 p.m.) and night (6 p.m.-6 a.m.), January 1, 2011, through December 31, 2013. Data were not collected between November 22, 2011, and April 27, 2013. 


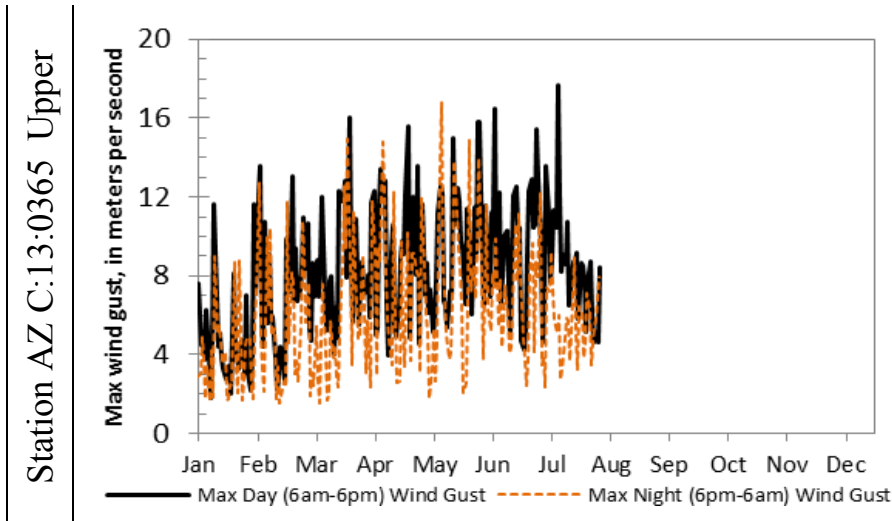

No Data Collected in 2013

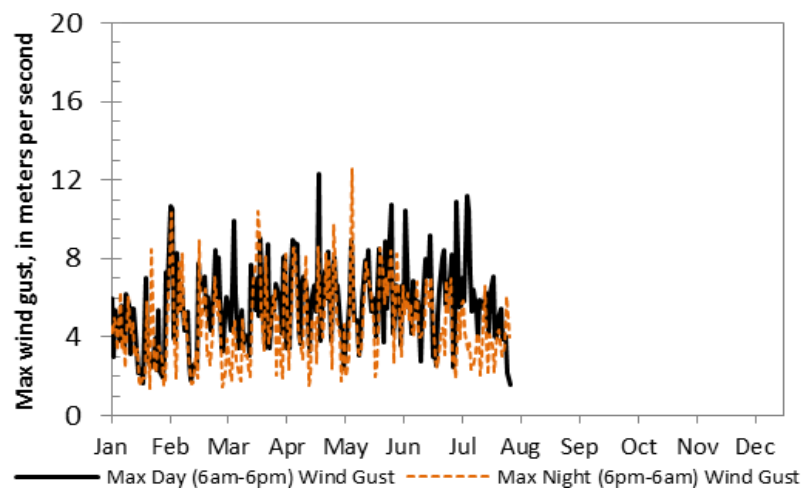

No Data Collected in 2013

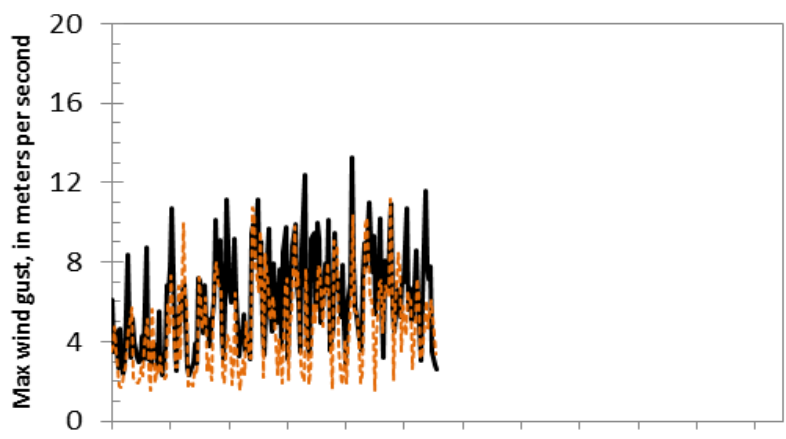

Jan Feb Mar Apr May Jun Jul Aug Sep Oct Nov Dec - Max Day (6am-6pm) Wind Gust ------- Max Night (6pm-6am) Wind Gust

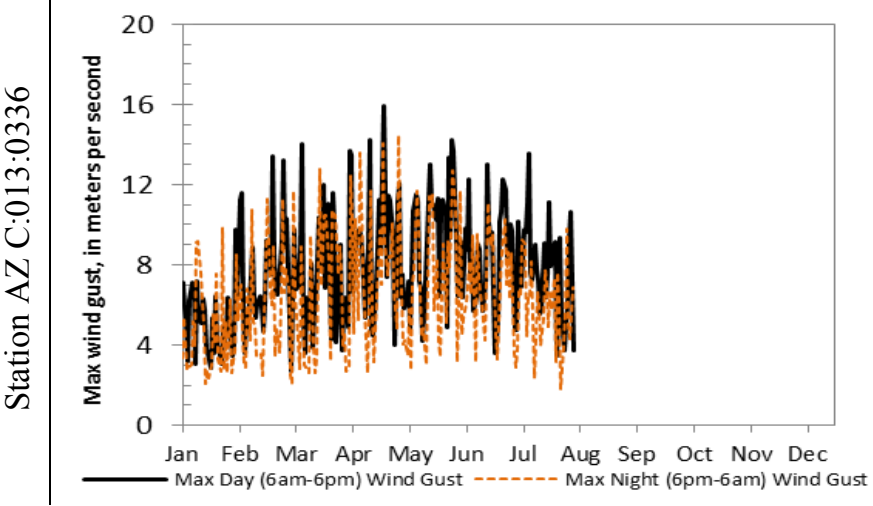

No Data Collected in 2013

Figure 5.-Continued 

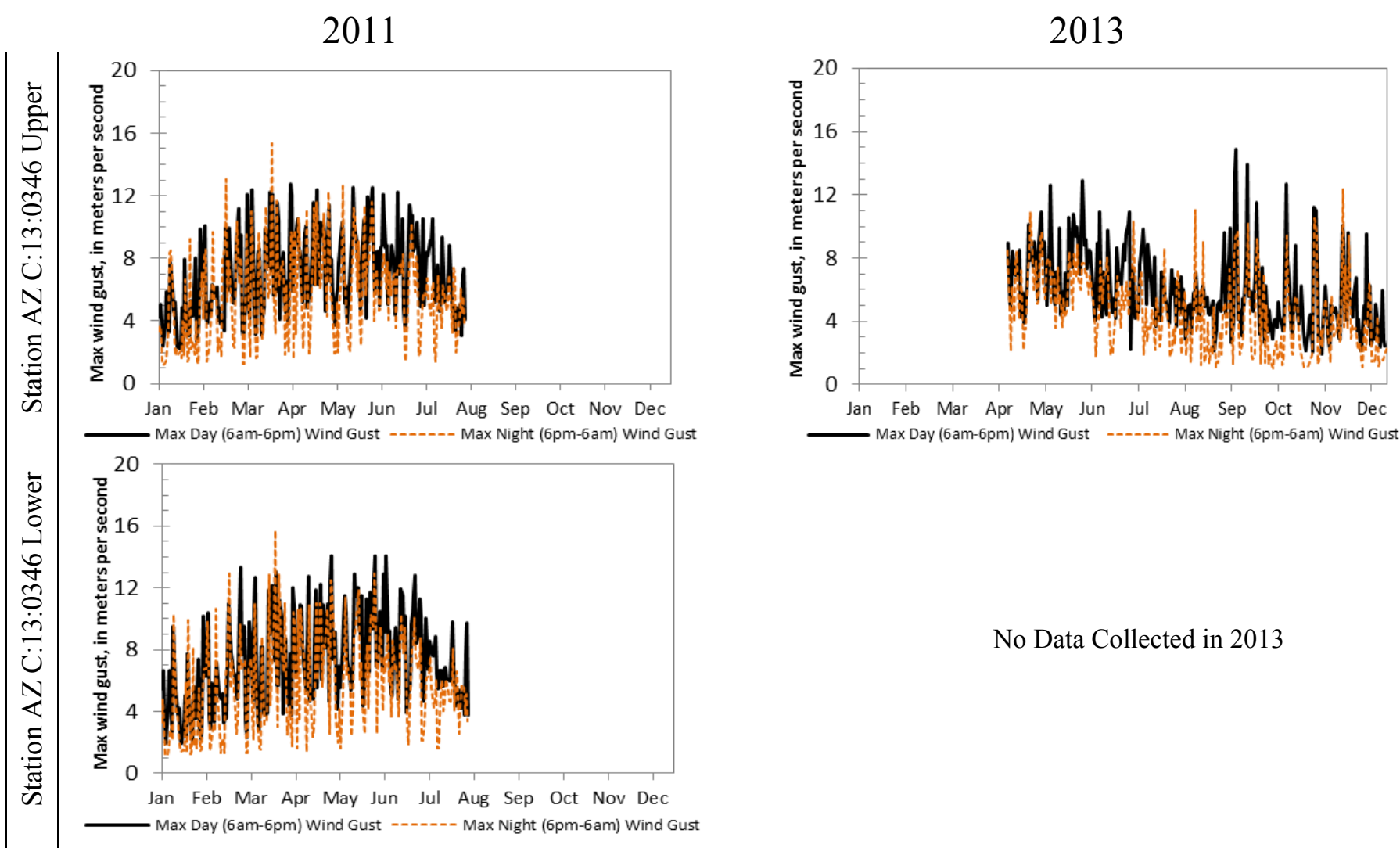

No Data Collected in 2013

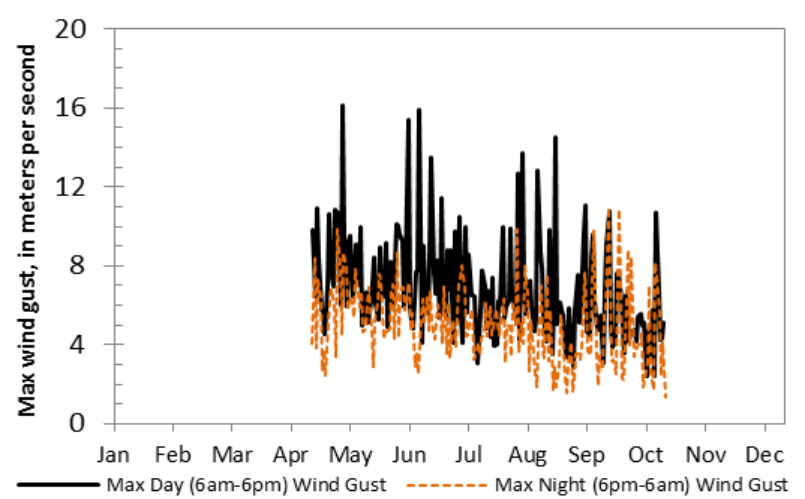

No Data Collected in 2013

Figure 5.-Continued 
2011

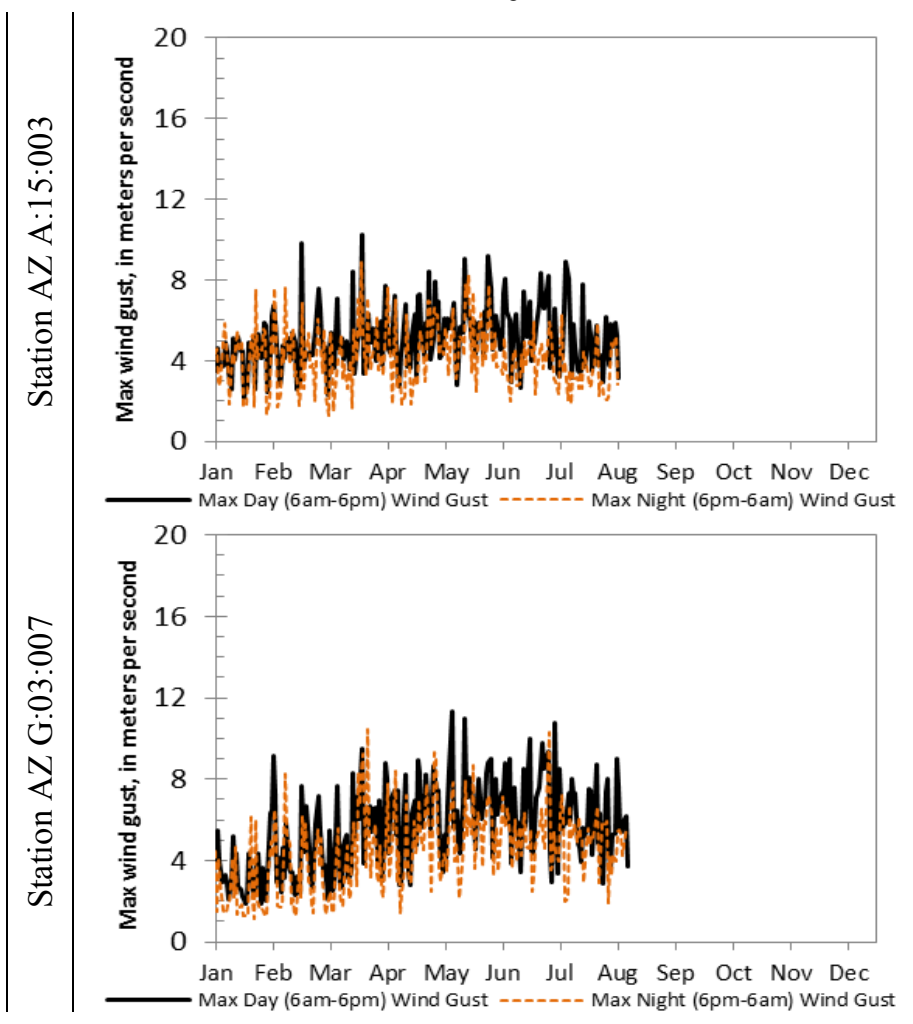

2013

No Data Collected in 2013

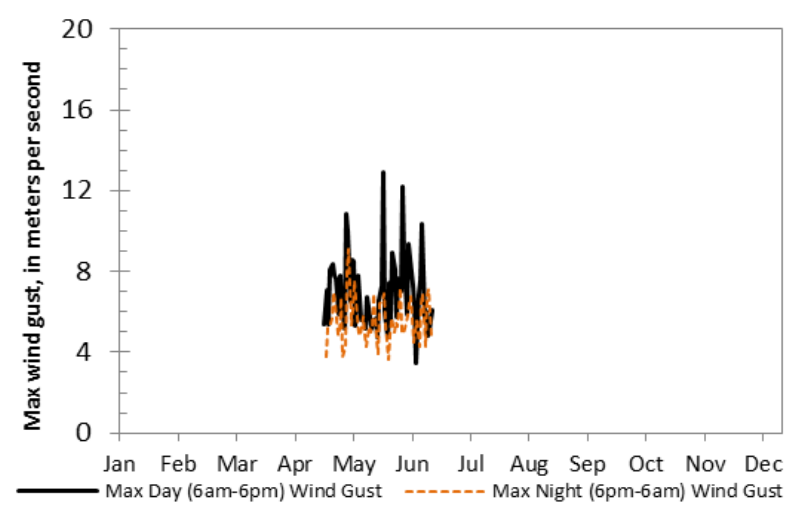

Figure 5.-Continued 
No Data Collected in 2011

No Data Collected in 2011
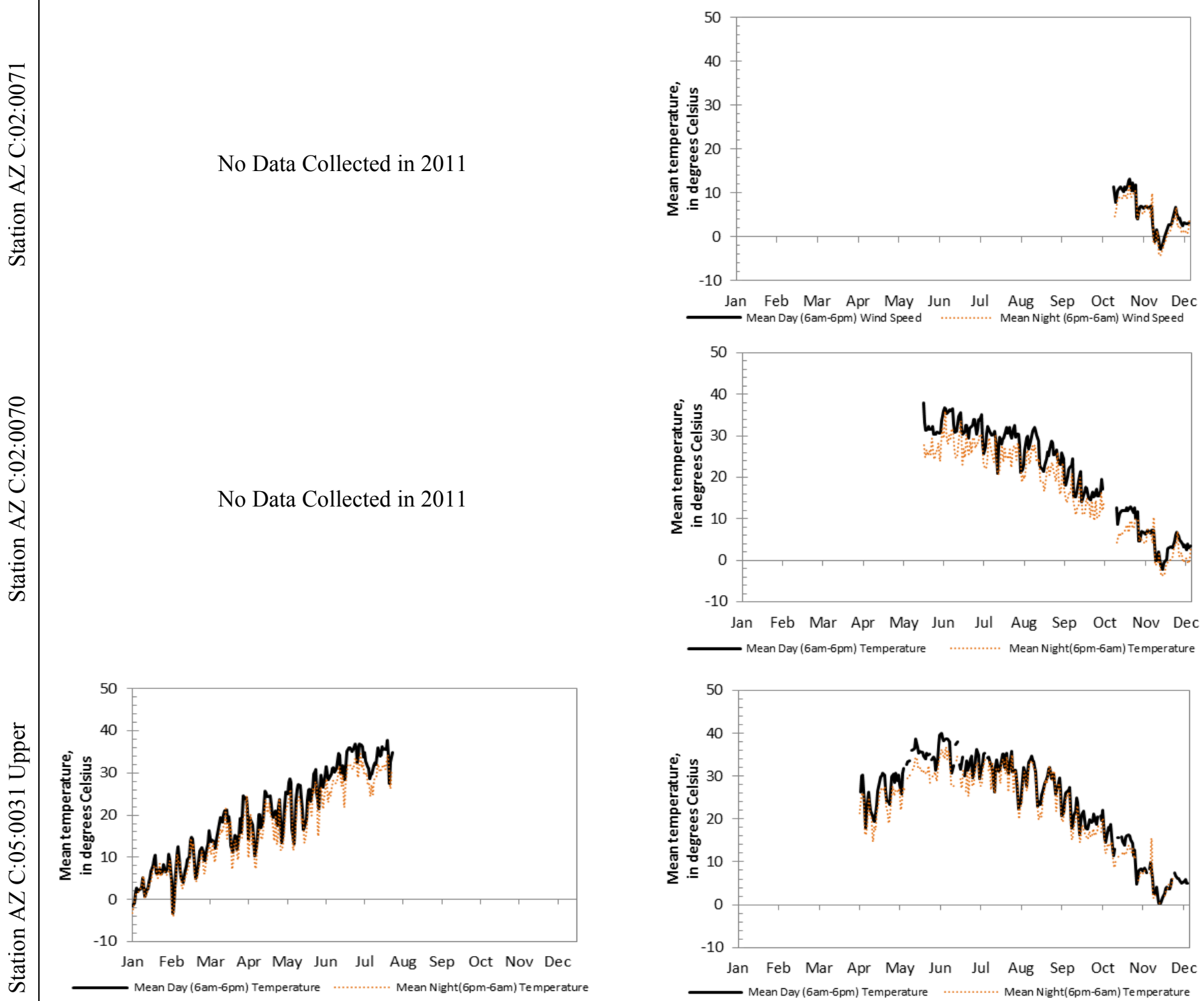

No Data Collected in 2013

Figure 6. Graphs showing mean air temperature recorded for 12 -hour day (6 a.m.-6 p.m.) and night (6 p.m.-6 a.m.), January 1, 2011, through December 31, 2013. Data were not collected between November 22, 2011, and April 27, 2013. 


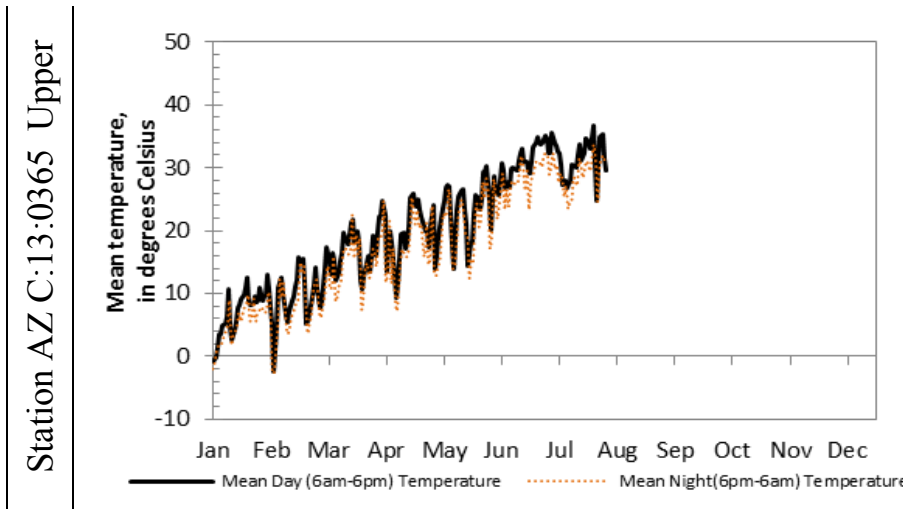

No Data Collected in 2013
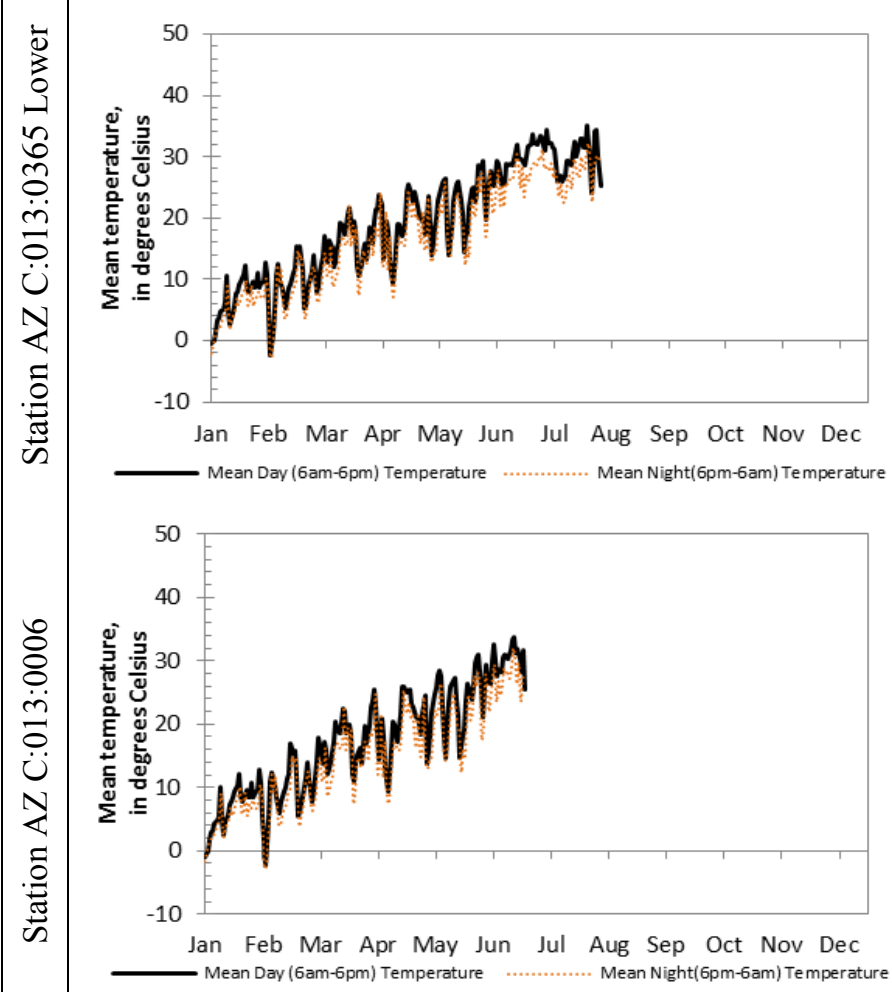

No Data Collected in 2013

No Data Collected in 2013

No Data Collected in 2013

Figure 6.-Continued 
2011
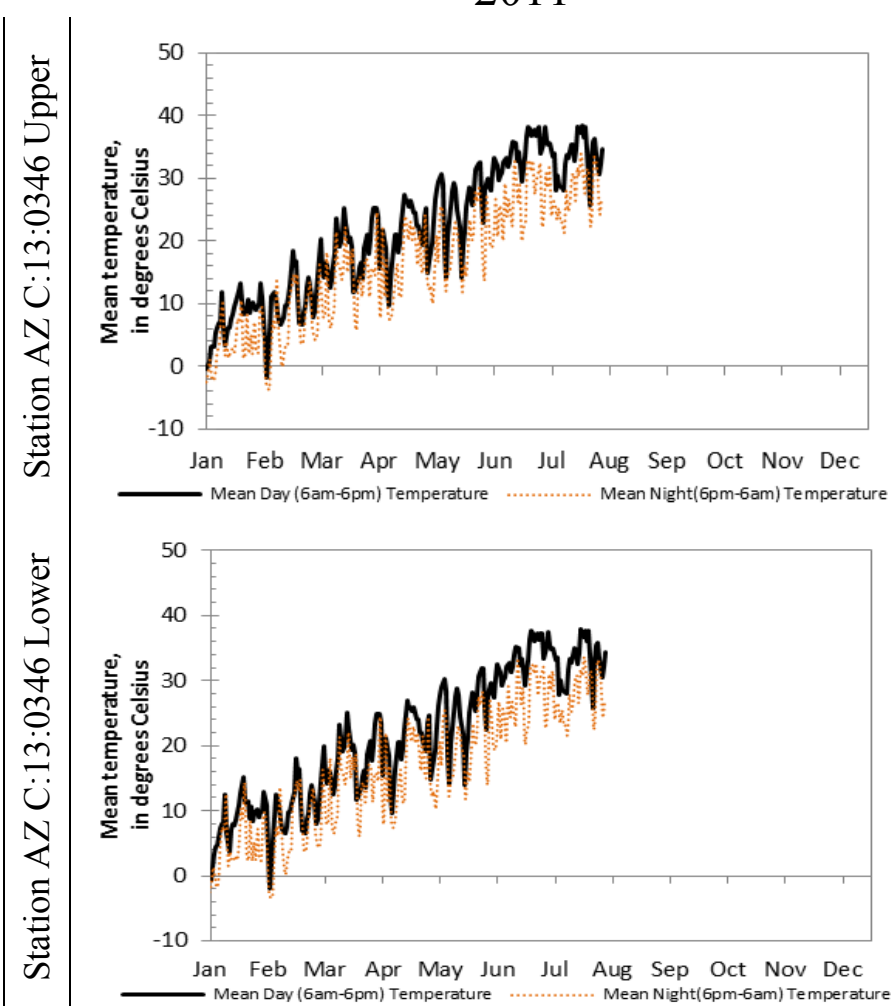

No Data Collected in 2011

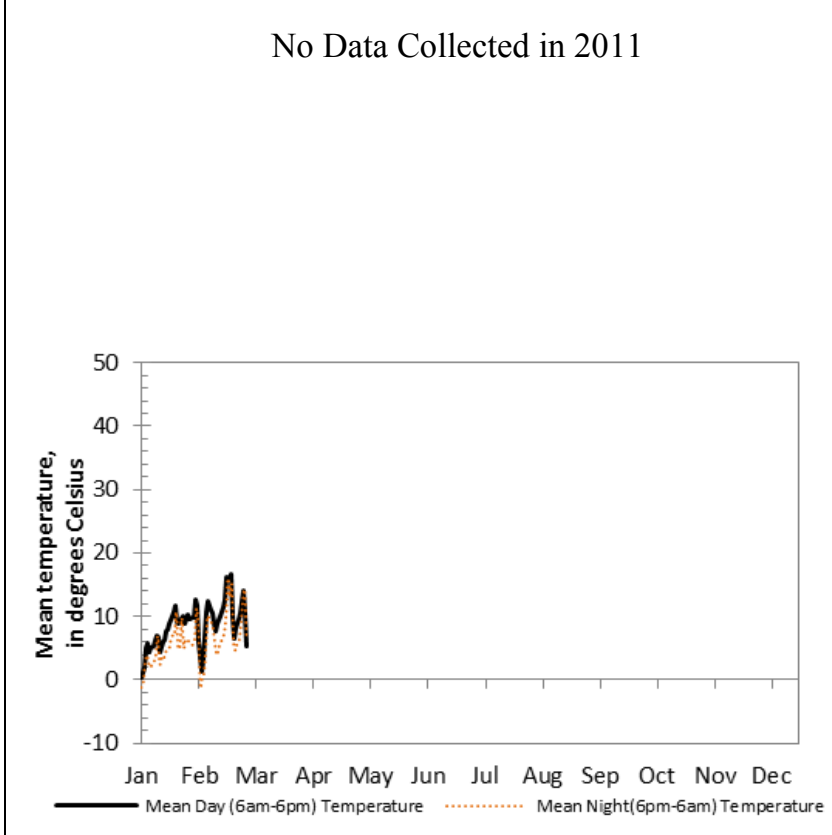

Figure 6.-Continued.
2013

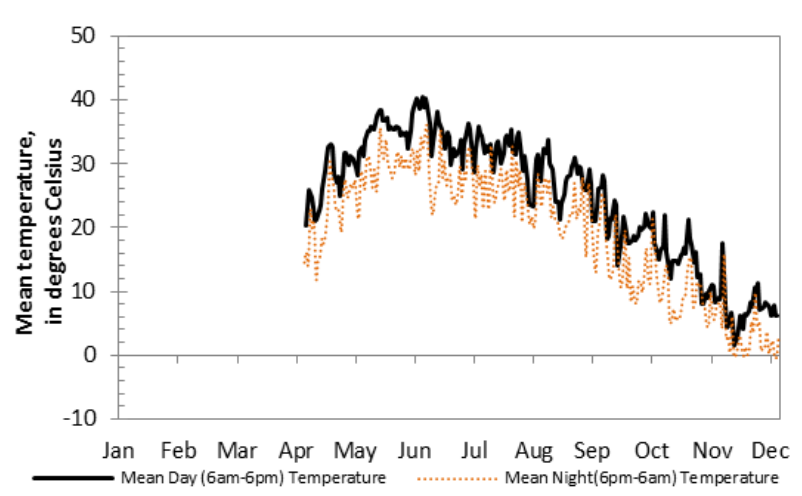

No Data Collected in 2013

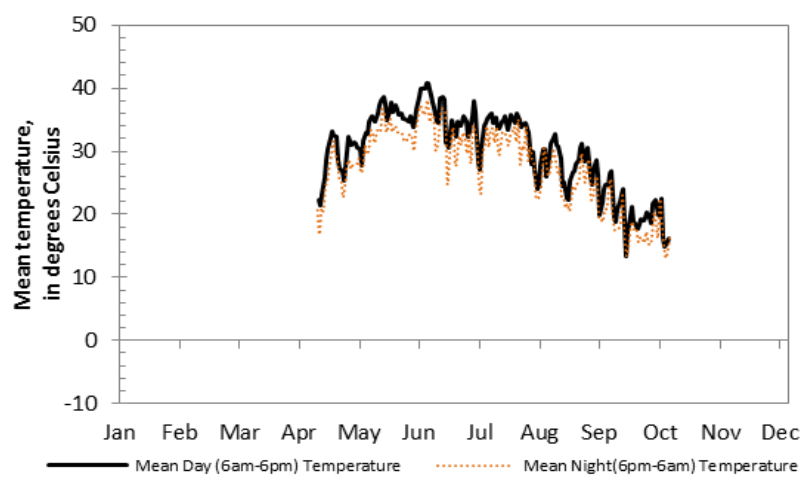

No Data Collected in 2013 
2011
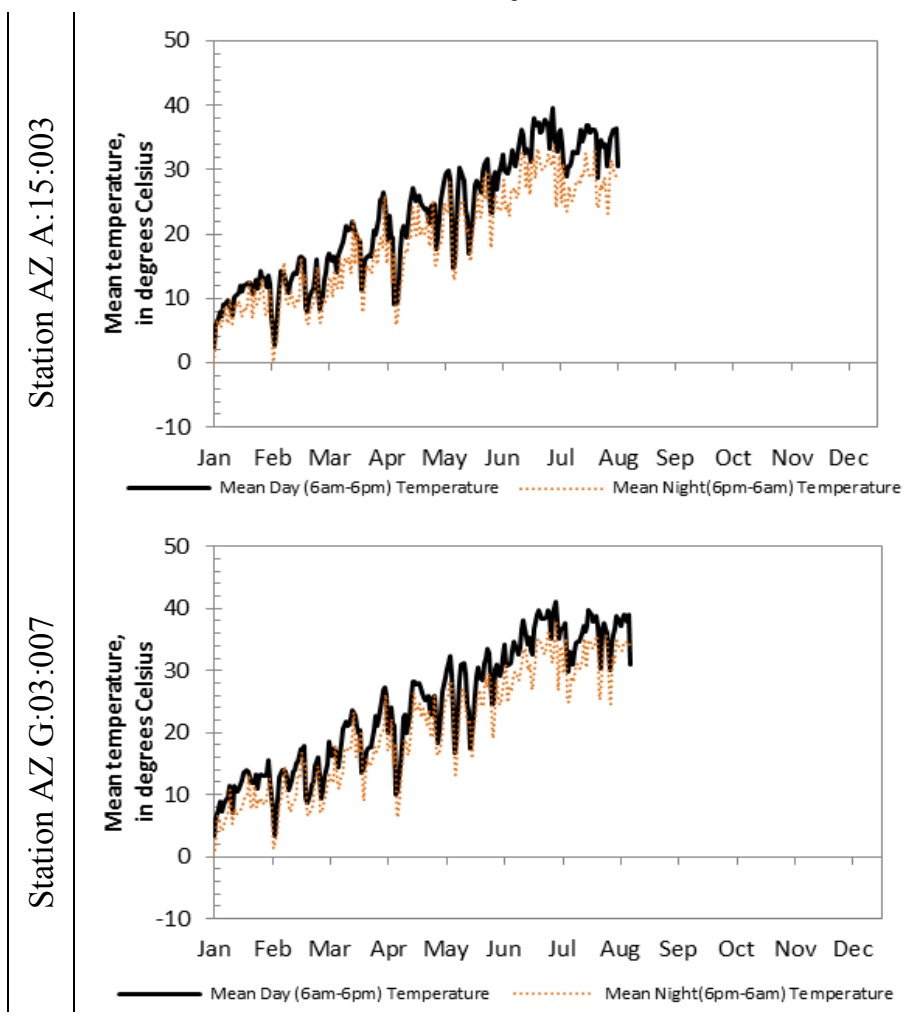

Figure 6.-Continued
2013

No Data Collected in 2013

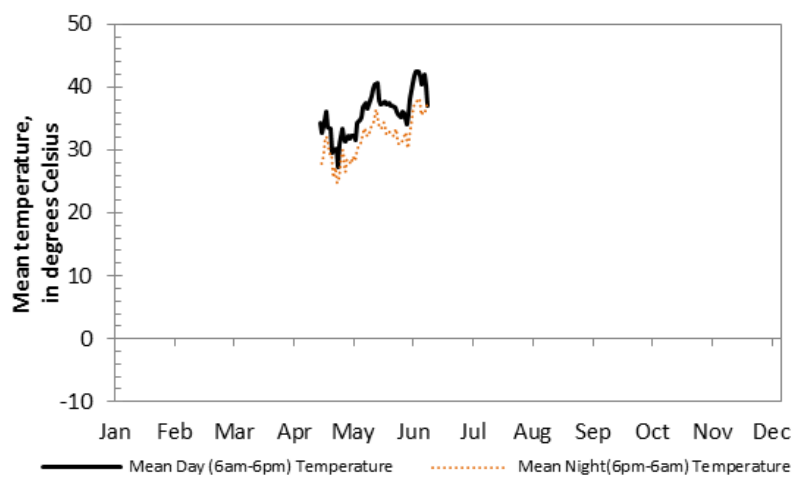


No Data Collected in 2011

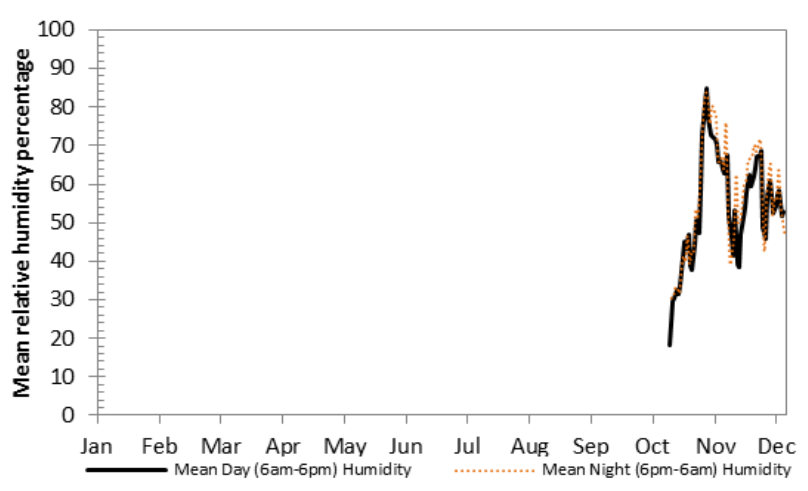

No Data Collected in 2011
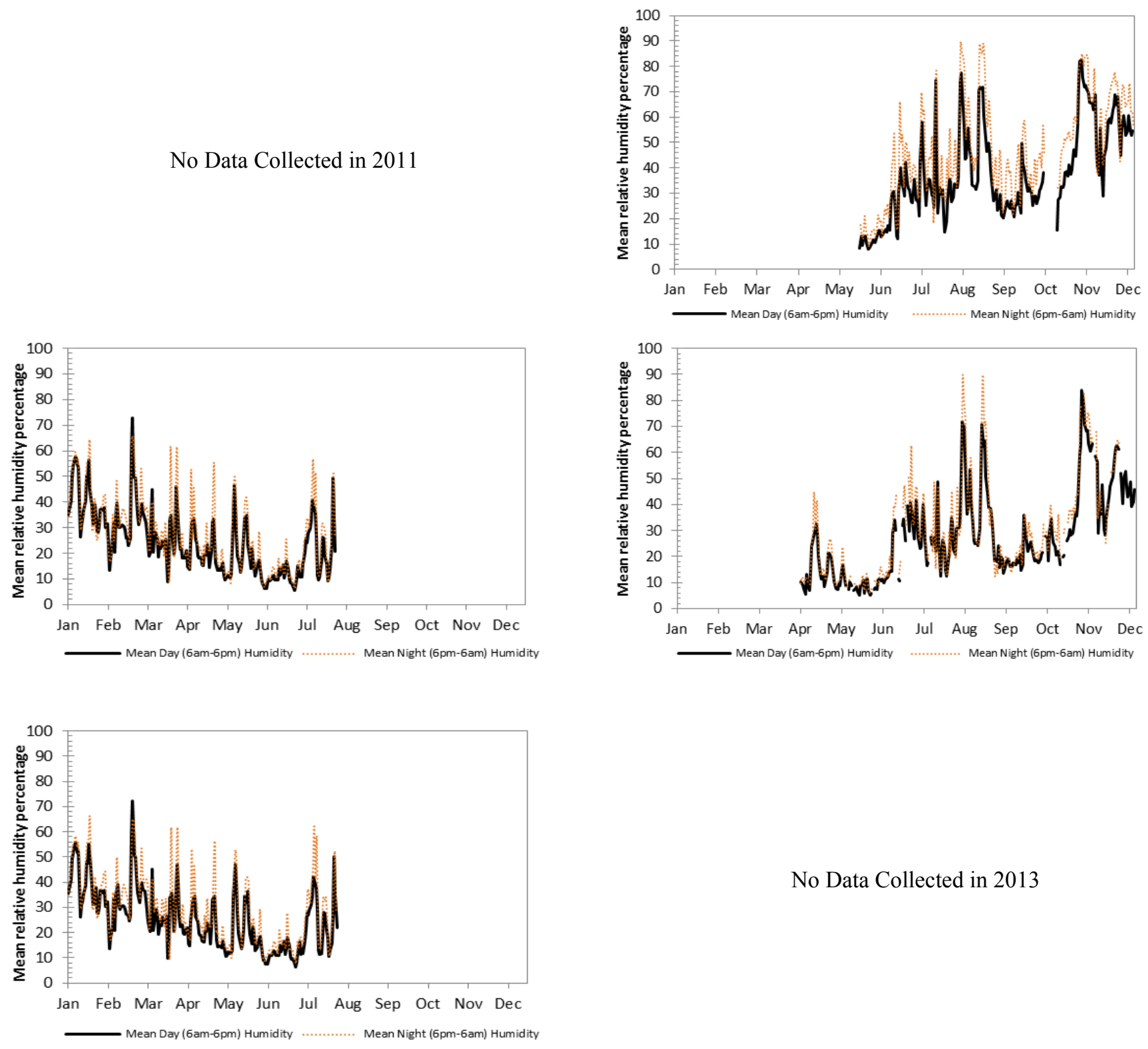

No Data Collected in 2013

Figure 7. Graphs showing mean relative humidity recorded for 12 -hour day (6 a.m.-6 p.m.) and night (6 p.m.-6 a.m.), January 1, 2011, through December 31, 2013. Data were not collected between November 22, 2011, and April 27, 2013. 


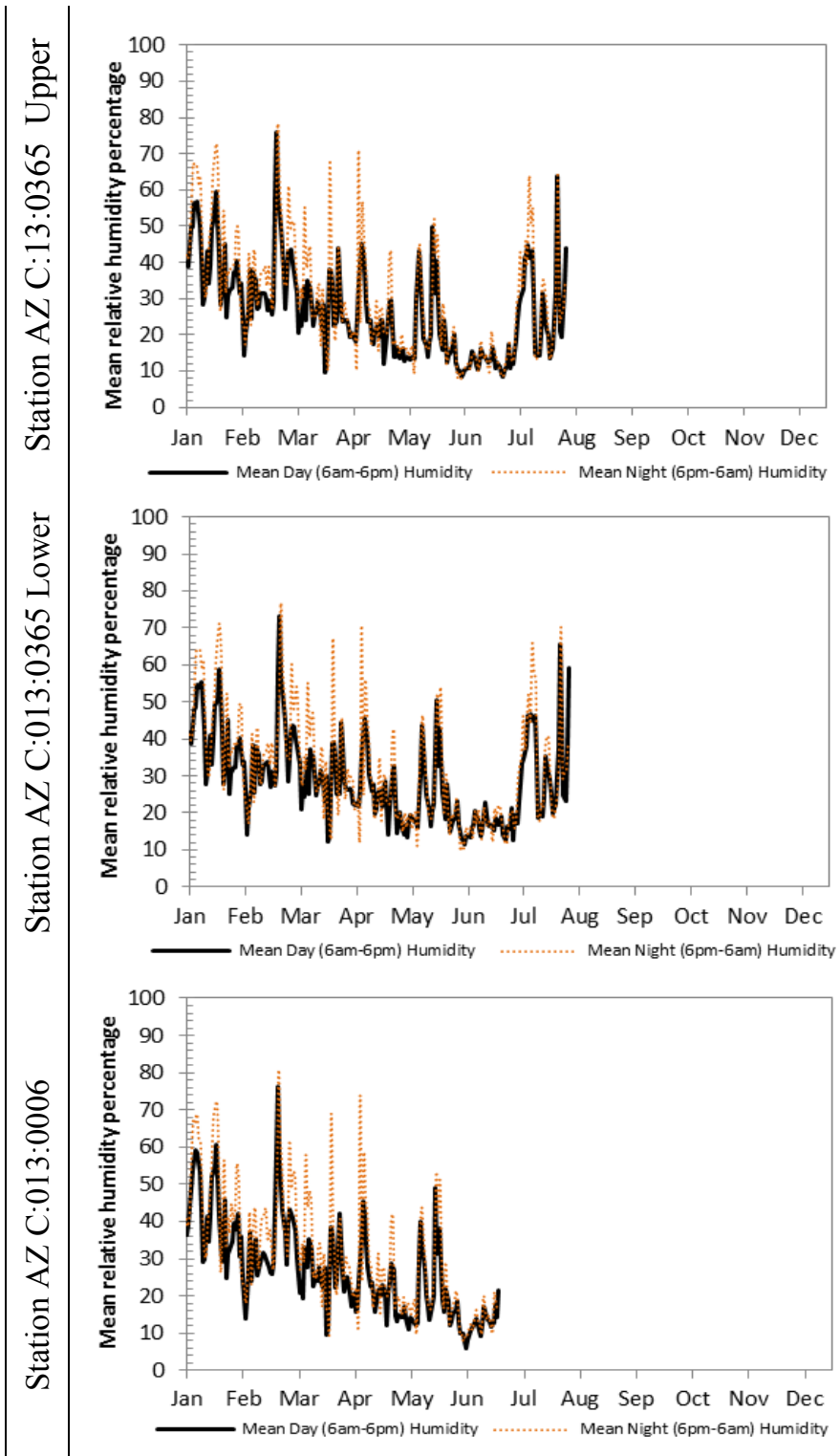

No Data Collected in 2013

No Data Collected in 2013

No Data Collected in 2013

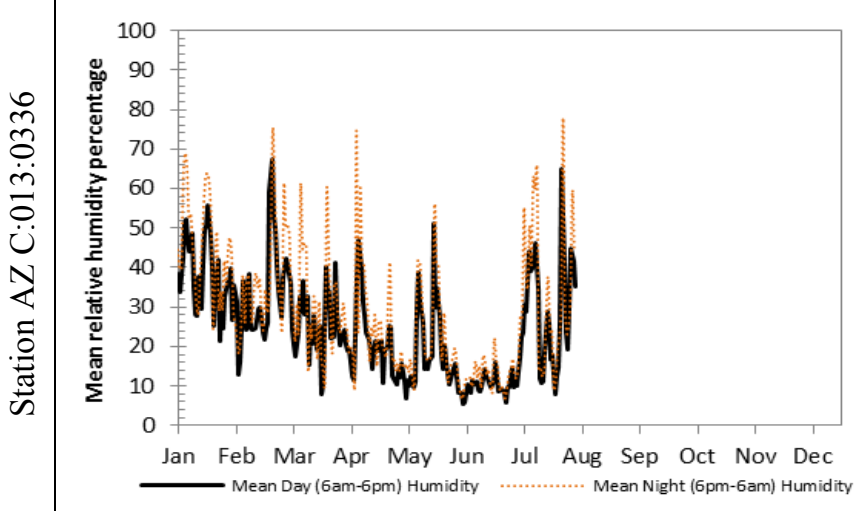

No Data Collected in 2013

Figure 7.-Continued 
2011

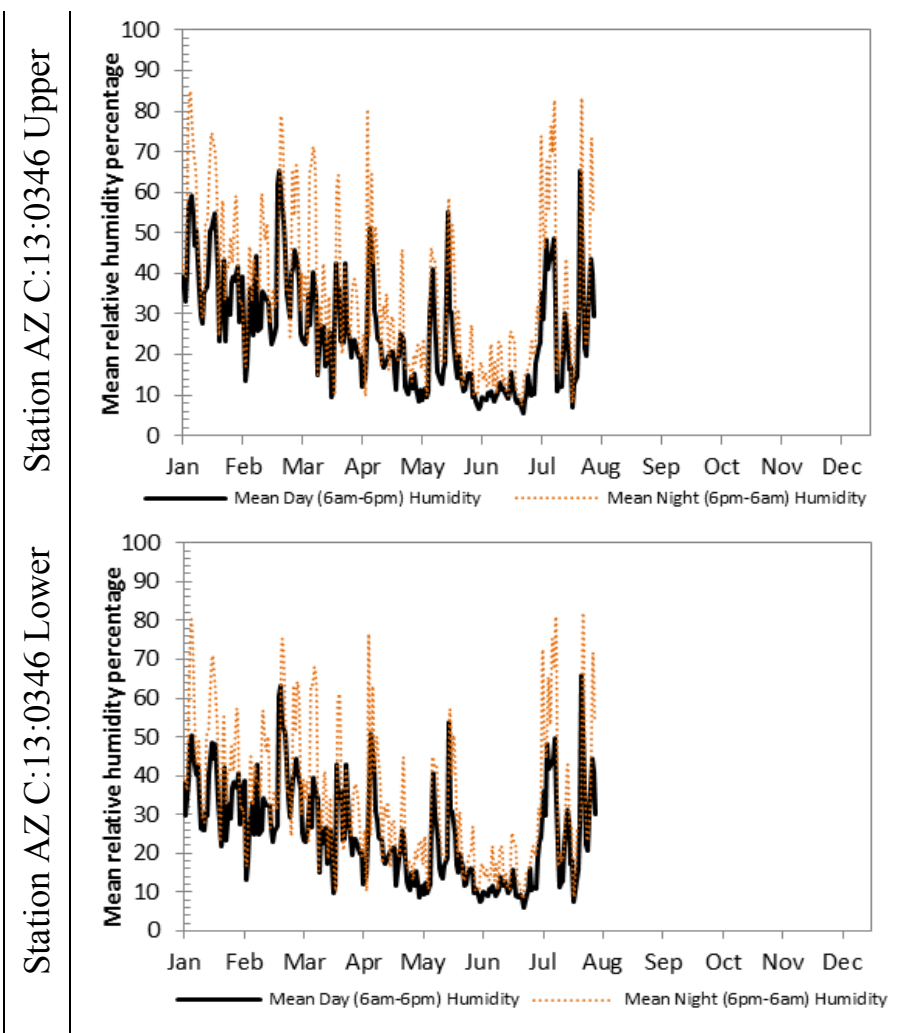

No Data Collected in 2011

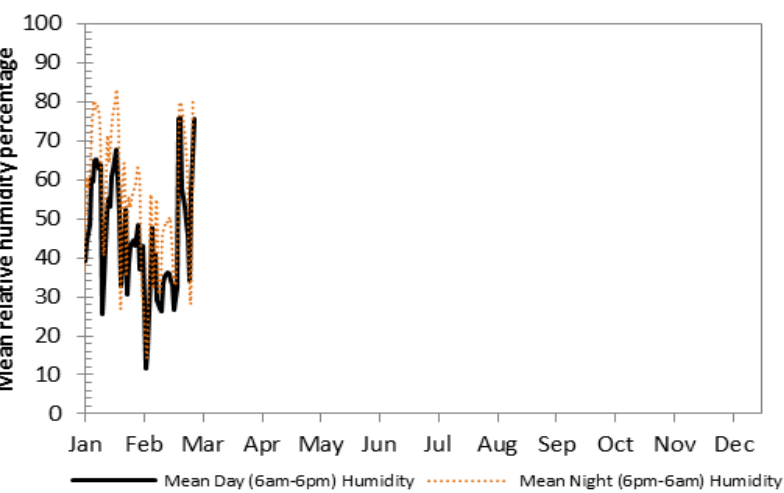

Figure 7.-Continued

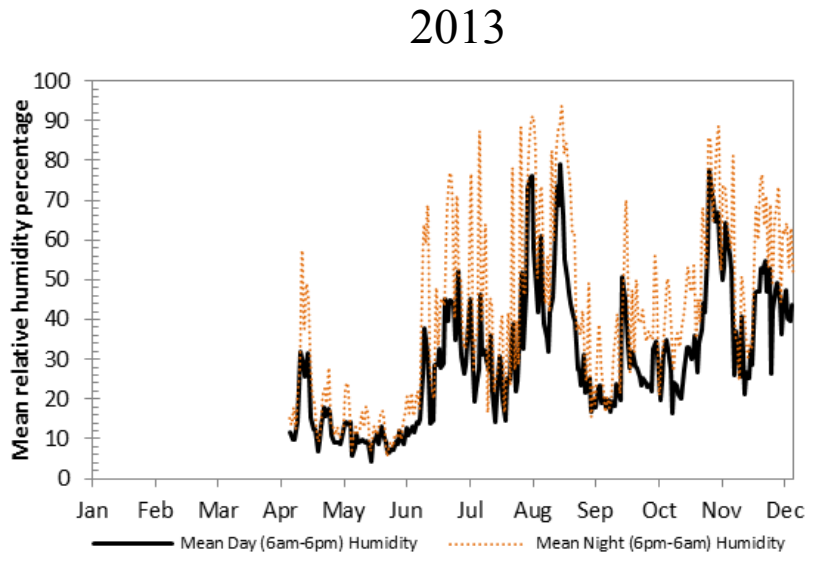

No Data Collected in 2013

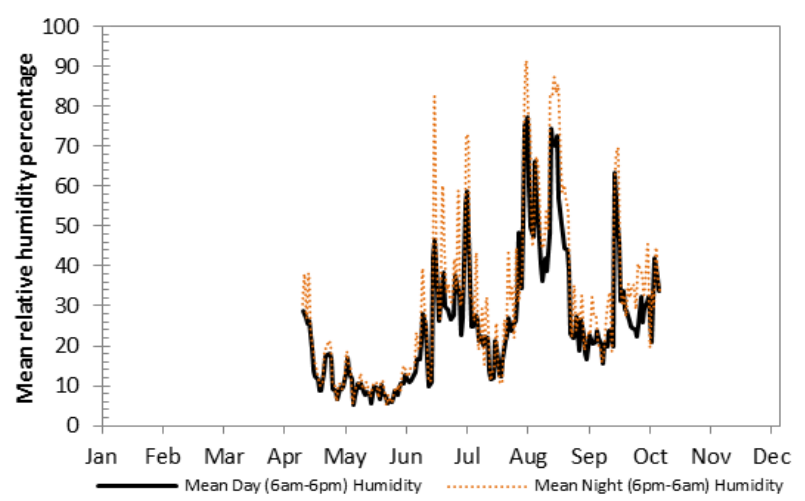

No Data Collected in 2013 
2011

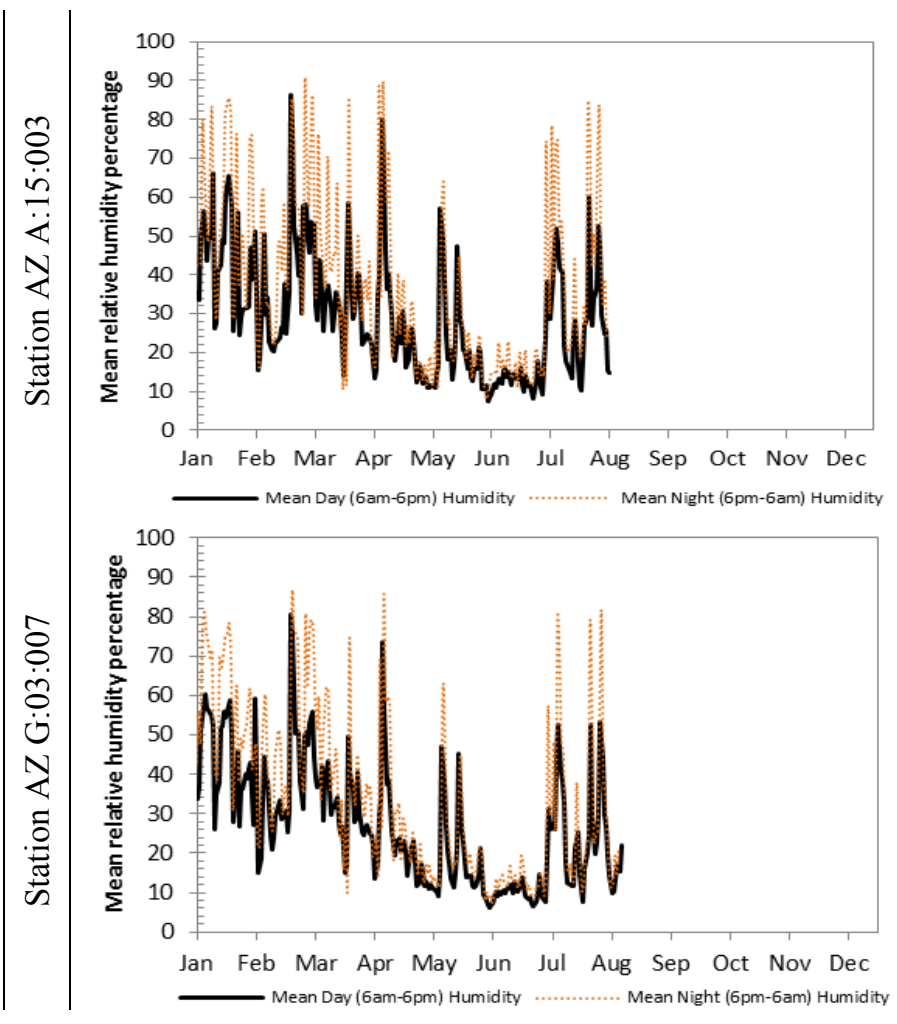

2013

No Data Collected in 2013

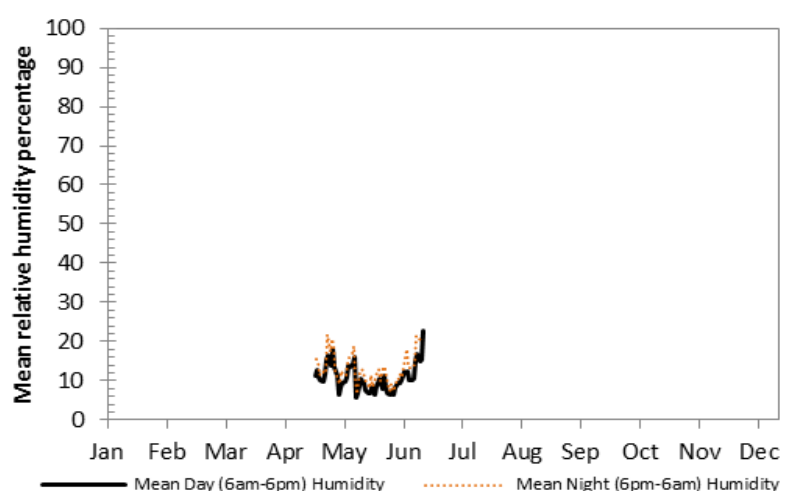

Figure 7.-Continued 
No Data Collected in 2011

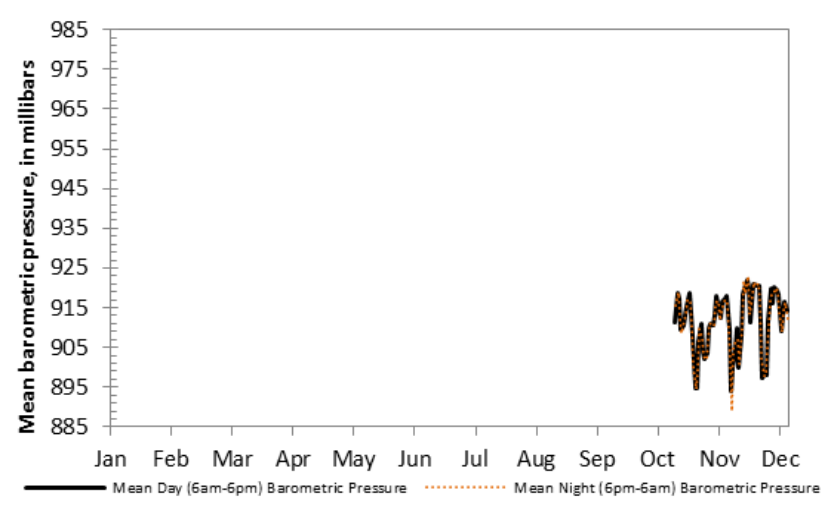

No Data Collected in 2011
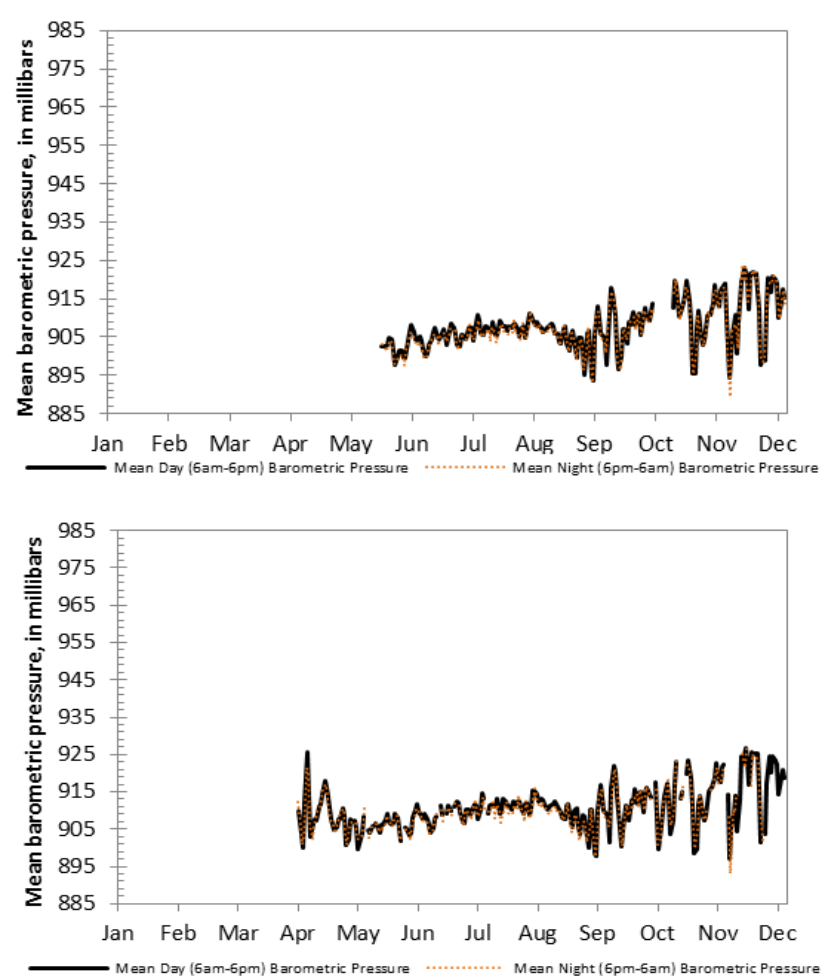

No Data Collected in 2013

Figure 8. Graphs showing mean barometric pressure recorded for 12-hour day (6 a.m.-6 p.m.) and night (6 p.m.-6 a.m.), January 1, 2011, through December 31, 2013. Data were not collected between November 22, 2011, and April 27, 2013. 


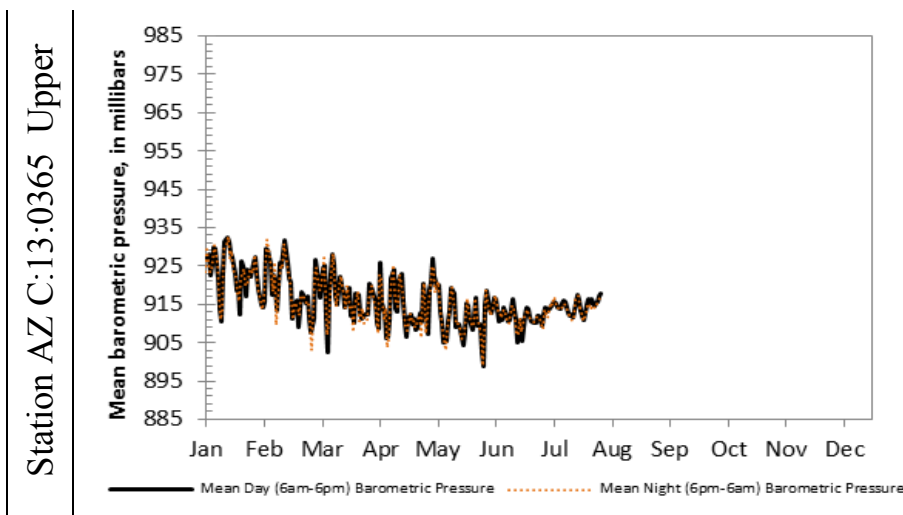

No Data Collected in 2013

No Data Collected in 2013

No Data Collected in 2013

No Data Collected in 2013

Figure 8.-Continued 
2011
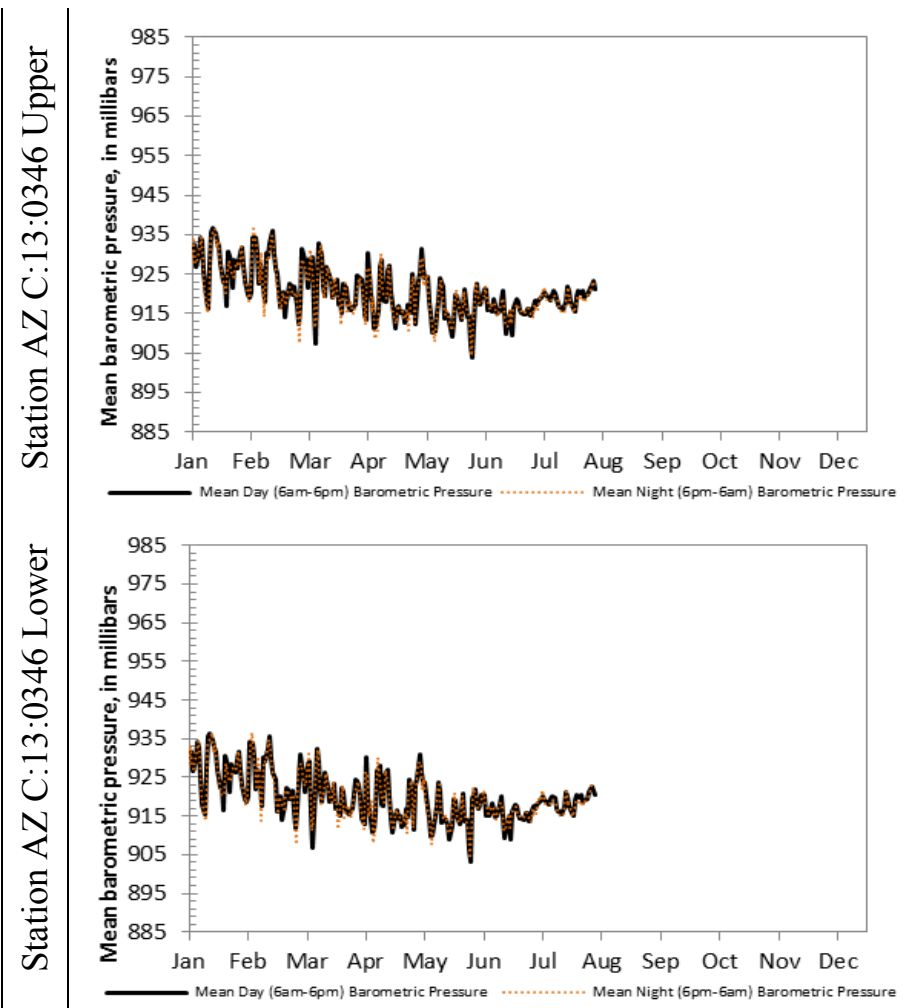

No Data Collected in 2011

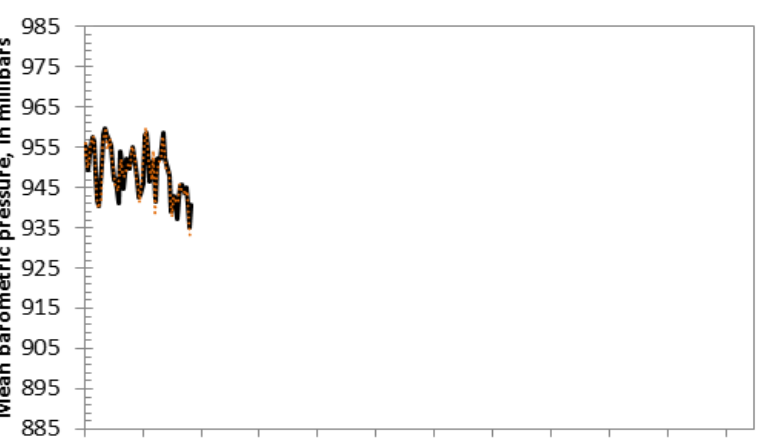

Jan Feb Mar Apr May Jun Jul Aug Sep Oct Nov Dec Mean Day (6am-6pm) Barometric Pressure ……….. Mean Night (6pm-6am) Barometric Pressure

Figure 8.-Continued
2013

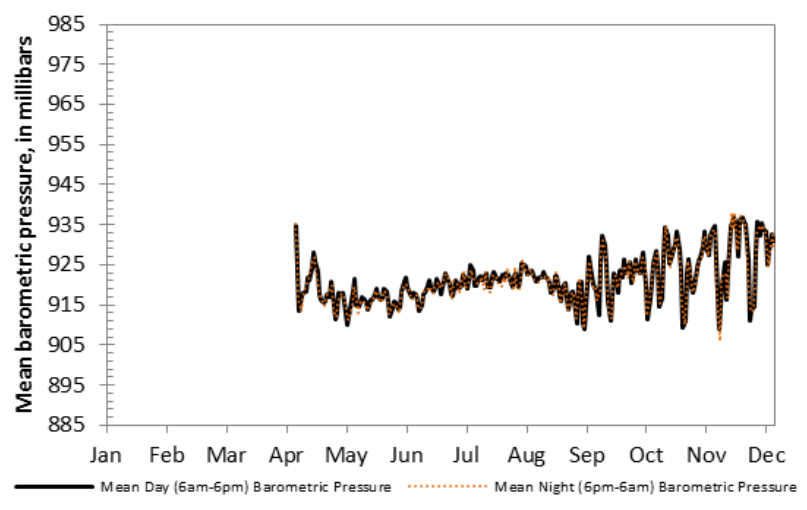

No Data Collected in 2013

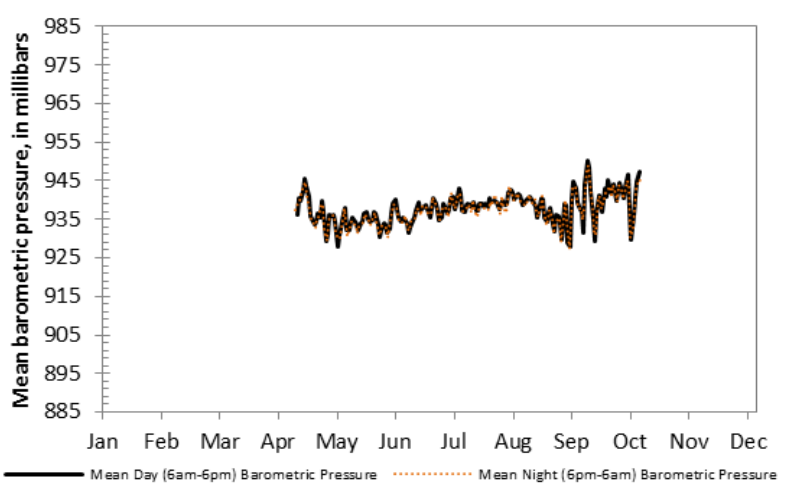

No Data Collected in 2013 
2011

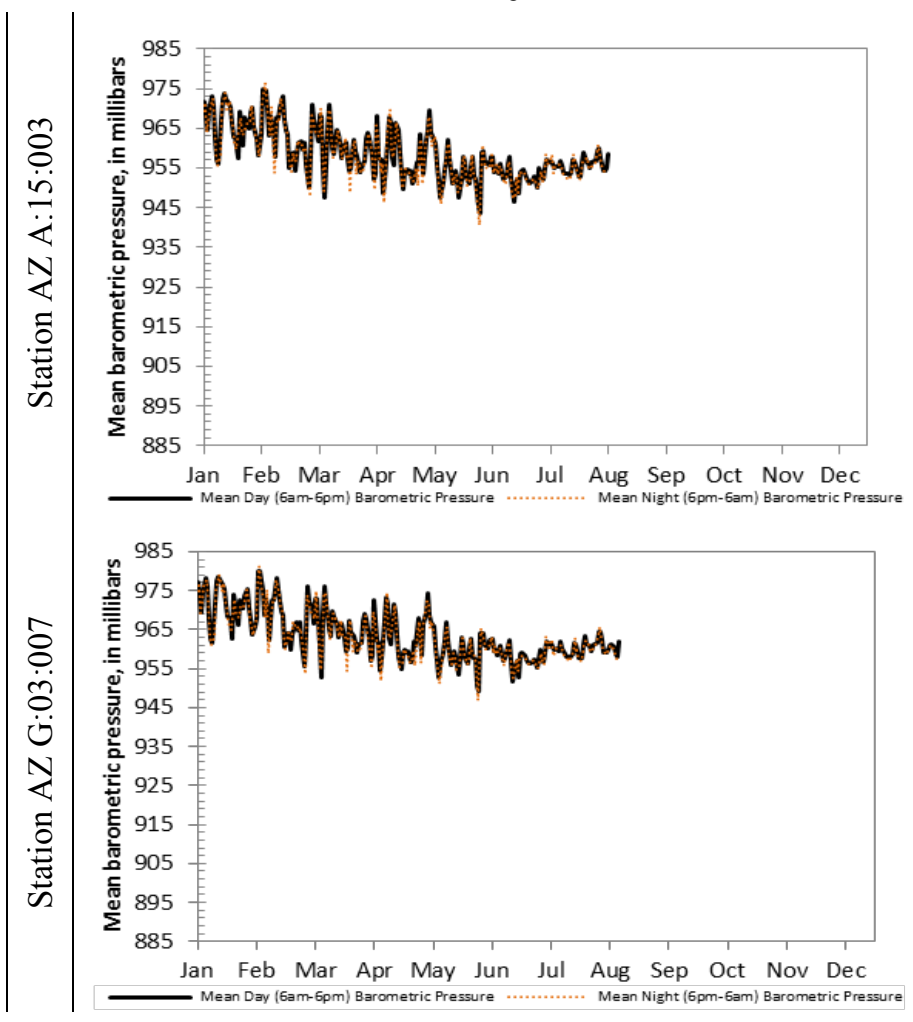

2013

No Data Collected in 2013

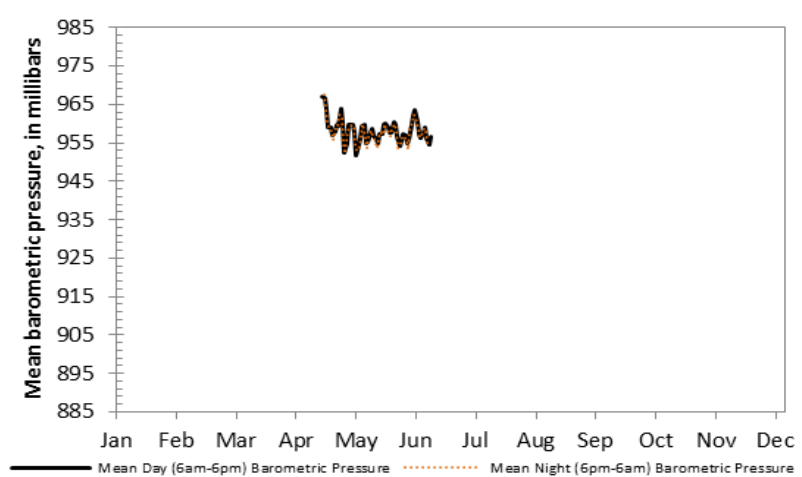

Figure 8.-Continued 
No Data Collected in 2011

No Data Collected in 2011
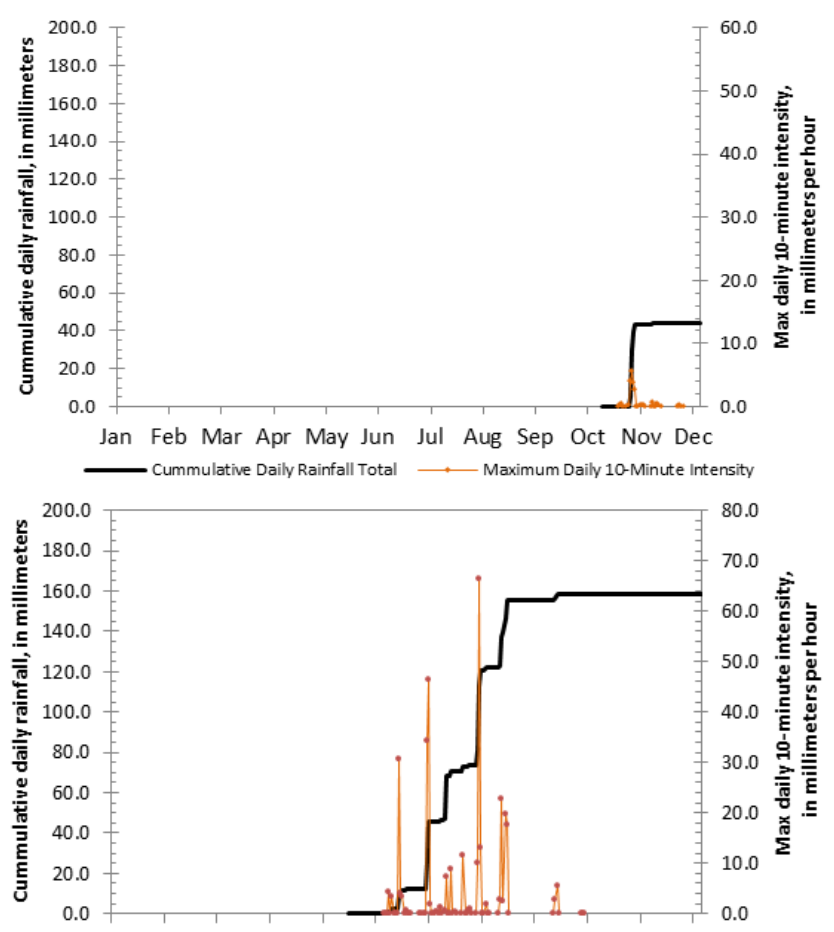

Jan Feb Mar Apr May Jun Jul Aug Sep Oct Nov Dec Cummulative Daily Rainfall Total —. Maximum Daily 10-Minute Intensity
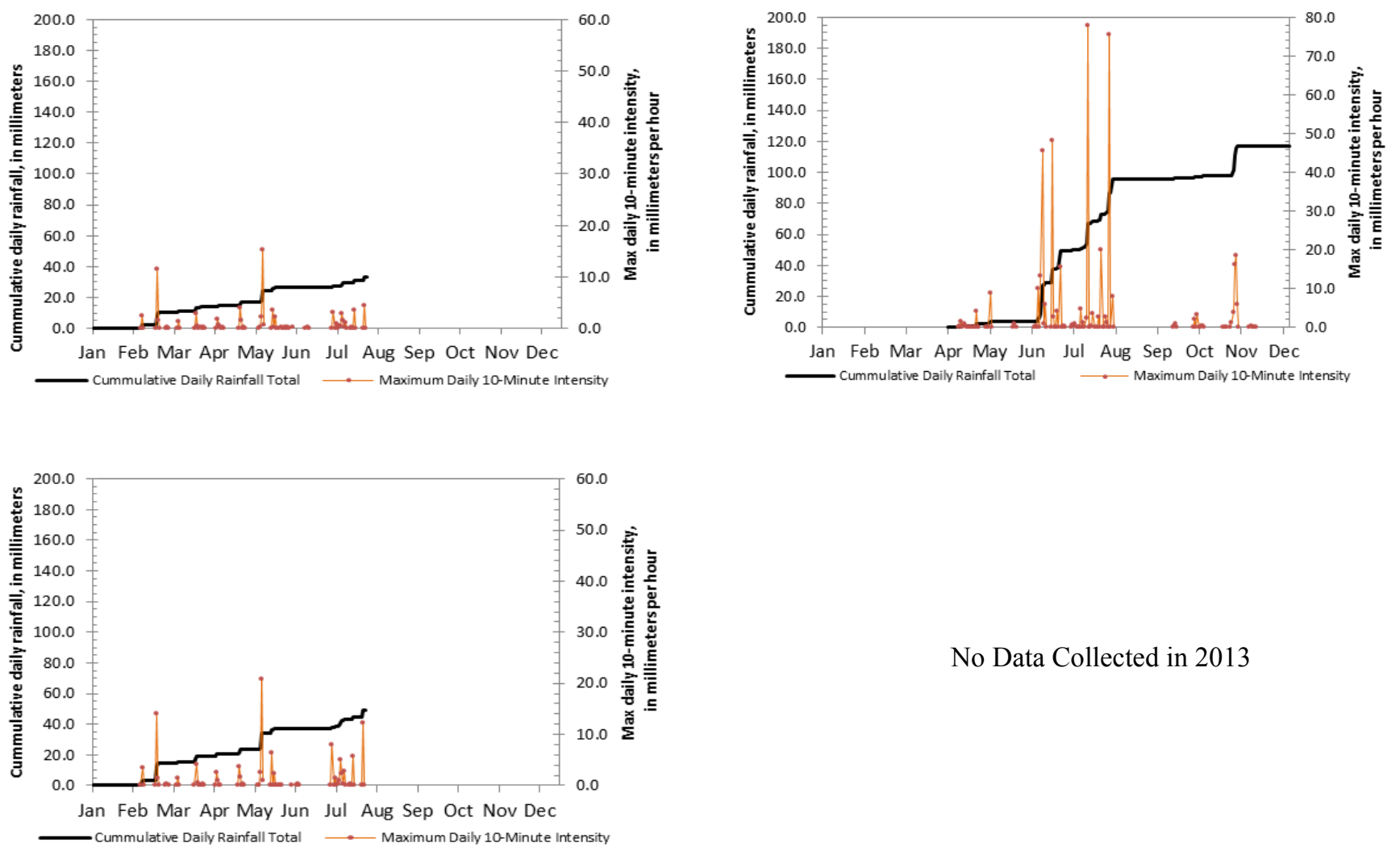

No Data Collected in 2013

Figure 9. Graphs showing cumulative daily rainfall and maximum daily 10-minute precipitation intensity, January 1, 2011, through December 31, 2013. Data were not collected between November 22, 2011, and April 27, 2013. 


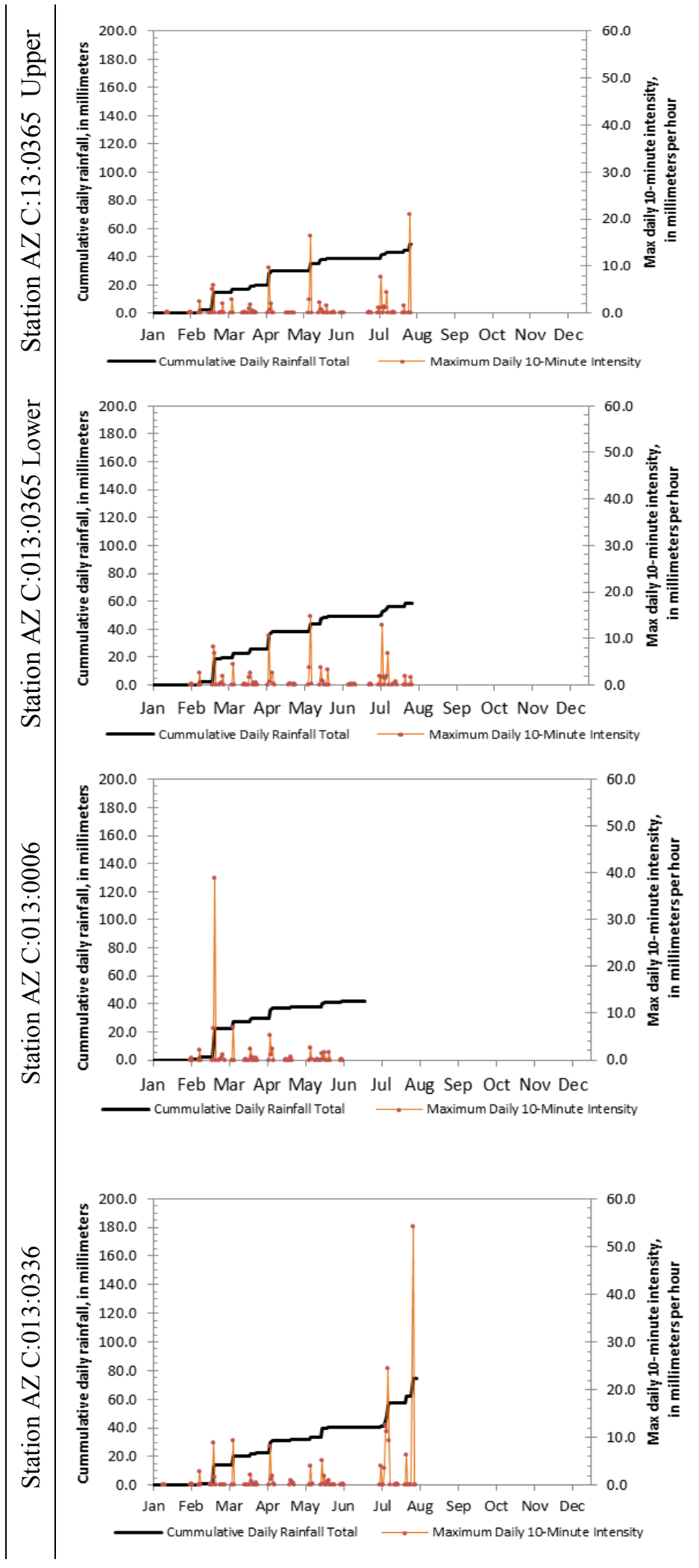

No Data Collected in 2013

No Data Collected in 2013

No Data Collected in 2013

No Data Collected in 2013

Figure 9.-Continued 
2011

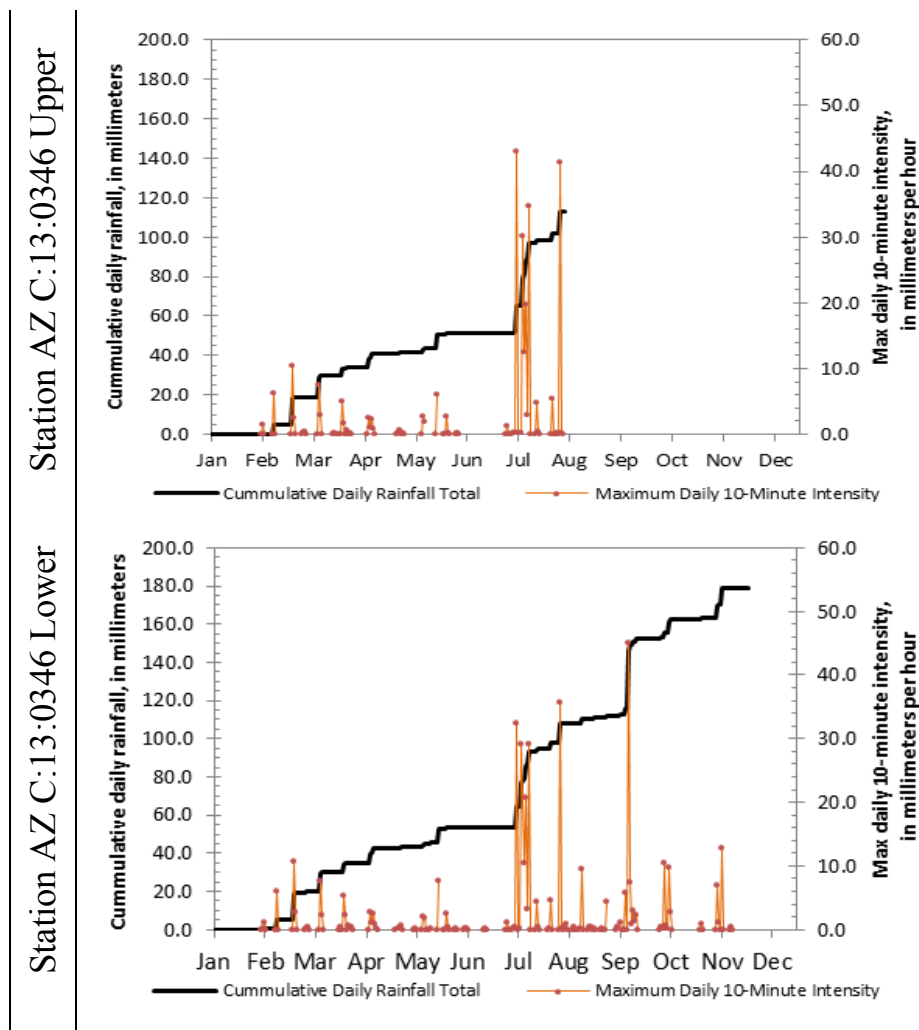

No Data Collected in 2011

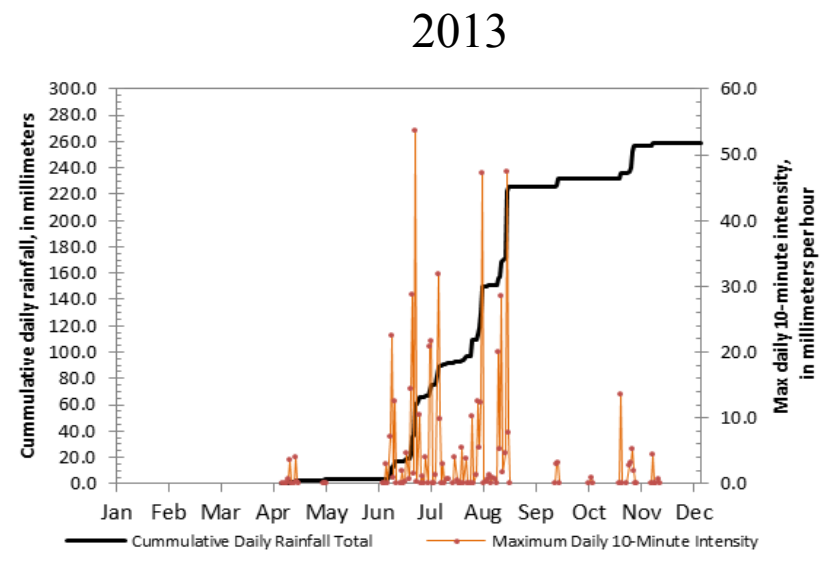

No Data Collected in 2013

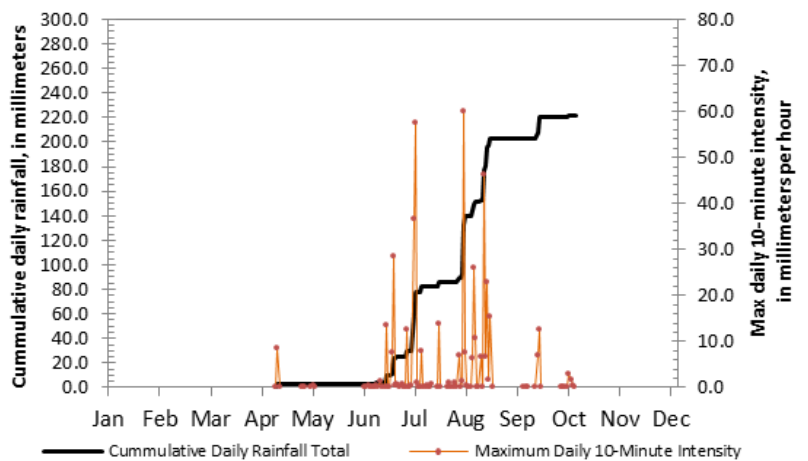

No Data Collected in 2013

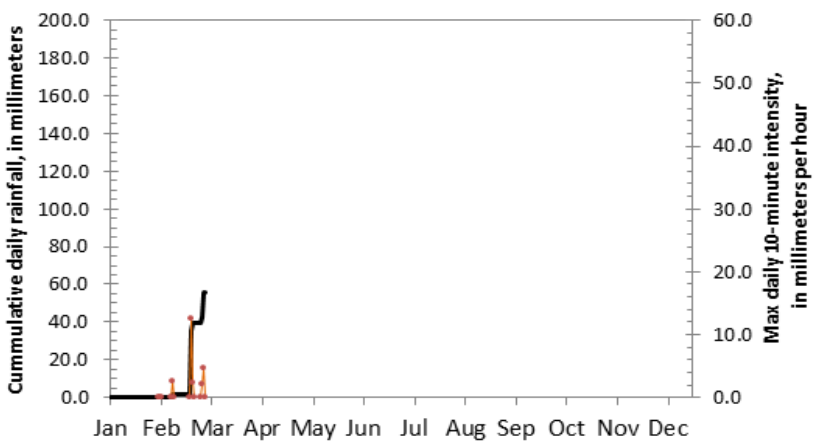

Nota Collected in 2013

Figure 9.-Continued 
2011

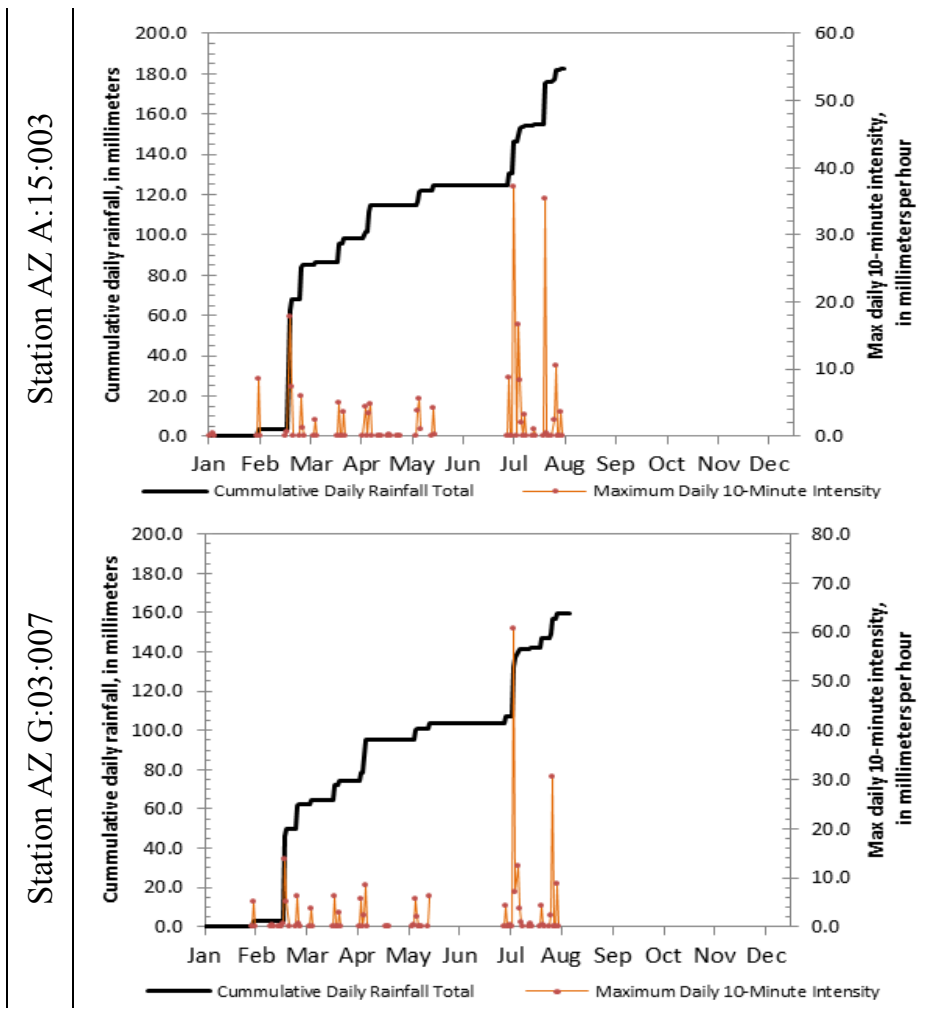

Figure 9.-Continued
2013

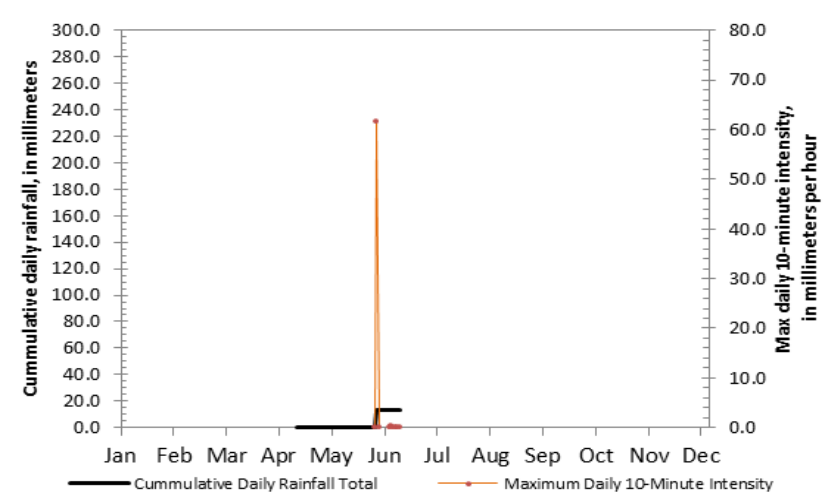

No Data Collected in 2013 
This page left intentionally blank 


\section{Appendixes}

Appendixes 1 and 2 are Microsoft ${ }^{\circledR}$ Excel files that can be downloaded from

http://pubs.usgs.gov/of/2014/1247. Appendixes 3 and 4 are Microsoft ${ }^{\circledR}$ Excel files or Comma-separated value (CSV) files that can be downloaded from http://pubs.usgs.gov/of/2014/1247.

Appendix 1. Explanation of Data Gaps within the Recording Period

Appendix 2. Potential Errors Identified during Quality Assessment

Appendix 3. Meteorological Data for Seven Weather Parameters, Glen Canyon Recreation Area, Arizona, January 2011-December 2013

Appendix 4. Meteorological Data for Seven Weather Parameters, Grand Canyon National Park, Arizona, February 2007-December 2010 
This page left intentionally blank 
Publishing support provided by the U.S. Geological Survey

Publishing Network, Menlo Park and Tacoma Publishing Service Centers

For more information concerning the research in this report, contact the SBSC staff, Southwest Biological Science Center

U.S. Geological Survey

2255 N. Gemini Drive

Flagstaff, AZ 86001

http://sbsc.wr.usgs.gov/ 
